EFFECTS OF ACIDIC PRECIPITATION ON THE WATER

QUALITY OF STREAMS IN THE LAUREL HILL AREA,

SOMERSET COUNTY, PENNSYLVANIA, 1983-86

By James L. Barker and Emitt C. Witt III

U.S . GEOLOGICAL SURVEY

Water-Resources Investigations Report 89-4113

Prepared in cooperation with

U.S. ENVIRONMENTAL PROTECTION AGENCY

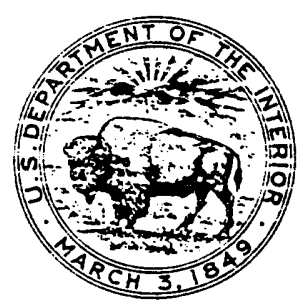

Harrisburg, Pennsylvania 


\author{
DEPARTMENT OF THE INTERIOR \\ MANUEL LUJAN, JR., Secretary \\ U.S. GEOLOGICAL SURVEY \\ Dallas L. Peck, Director
}

For additional information write to:

District Chief

U.S. Geological Survey 4th Floor, Federal Building P.0. Box 1107

Harrisburg, Pennsylvania 17108-1107
Copies of this report can be purchased from:

U.S. Geological Survey Books and Open-File Reports Section Federal Center, Bldg 810 Box 25425

Denver, Colorado 80225 


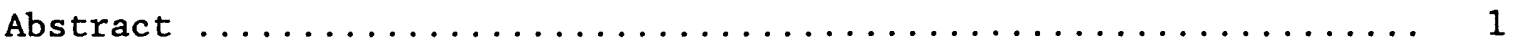

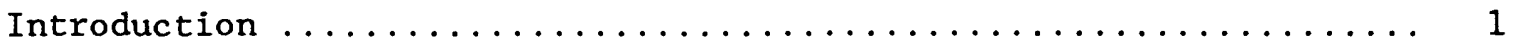

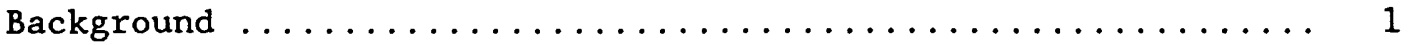

Purpose and scope ................................ 2

Regional characteristics .......................... 2

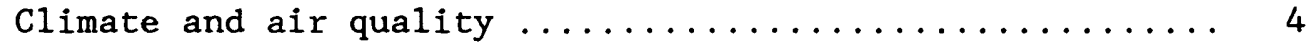

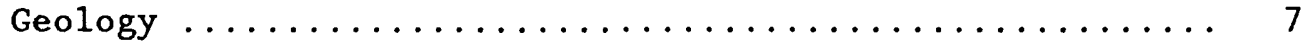

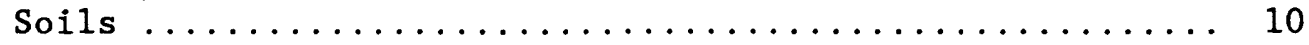

Site descriptions .............................. 10

North Fork Bens Creek at North Fork Reservoir .......... 10

South Fork Bens Creek near Thomasdale .............. 10

North Branch Quemahoning Creek at Roytown ........... 12

Garys Run near Barronvale ................... 12

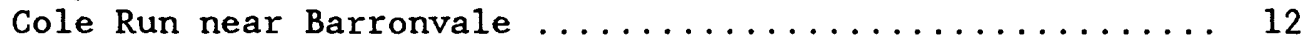

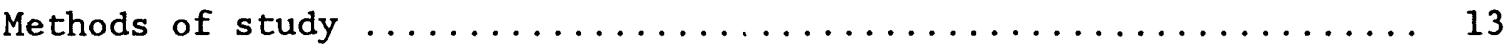

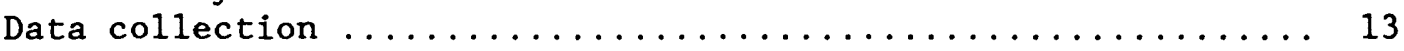

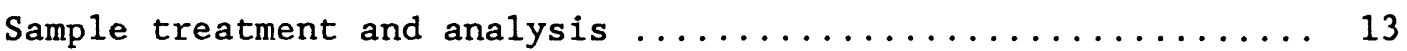

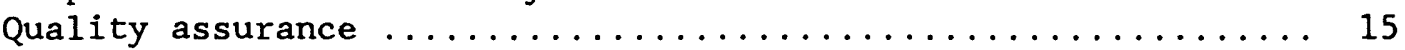

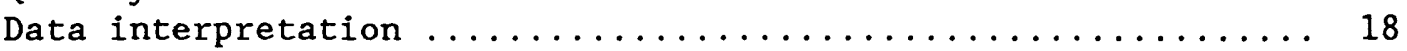

Hydrologic information used in analysis $\ldots \ldots \ldots \ldots \ldots \ldots \ldots \ldots \ldots$

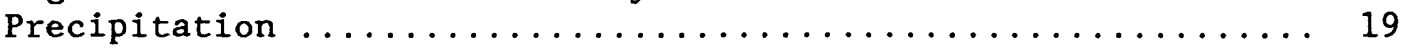

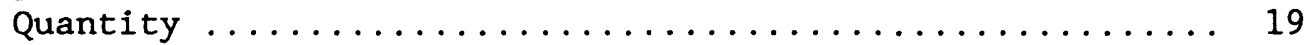

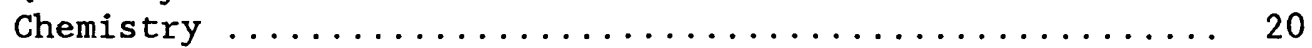

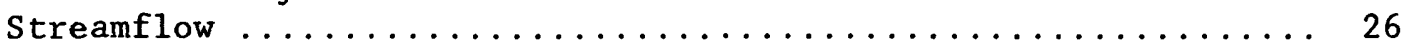

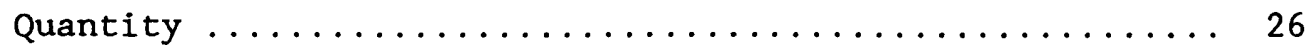

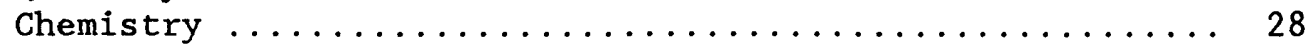

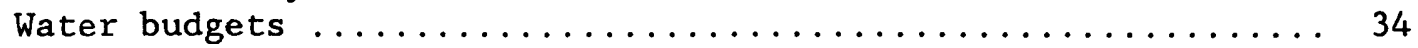

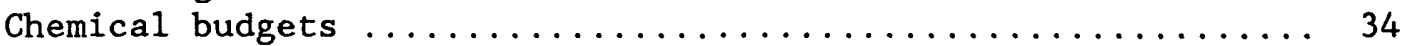

Effects of acidic precipitation on the water quality of streams

in the Laurel Hill area ........................... 40

Relations among $\mathrm{pH}$, chemical concentration, and discharge .... 40

Interactions of acid precipitation on watershed soils ....... 66

During input of first 20 percent of constituents in acidic precipitation ................... 67

During input of 50 percent of constituents in acidic precipitation .................... 68

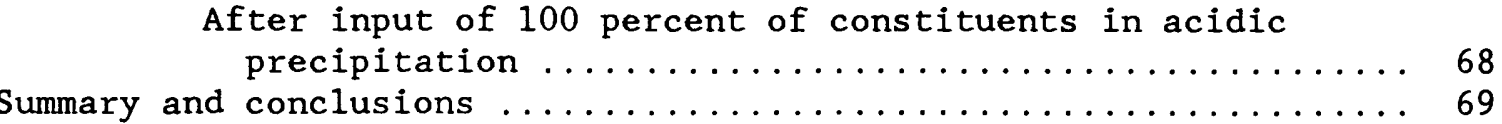

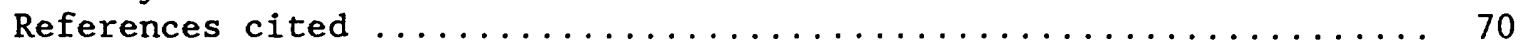




\section{ILLUSTRATIONS}

Figures 1-4.--Maps showing:

1.--Location of study basins and precipitation

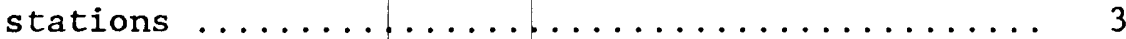

2.--Density of sulfur dioxide emissions to the atmosphere in Pennsylvania by counties ......... 5

3.--pH of wet deposition (annual volume-weighted average) in the United States ............. 6

4.--Geology of study basins ................. 8

5-19. --Graphs showing:

5.--Generalized geologic section of the Laurel Hill anticline in the vicinity of: A. North Fork

Bens Creek; B. Garys Run ................ 9

6.--Weekly precipitation and mean $\mathrm{pH}$ in South Fork Bens Creek watershed, 1984-85 water years ...... 19

7. - - Mean chemical composition of precipitation ....... 20

8.--Separation of streamflow components, South Fork Bens Creek, 1984 water year .............. 26

9.--Separation of streamflow components, South Fork Bens Creek, 1985 water year .............. 27

10. - - Separation of streamflow components, North Fork Bens Creek, 1985 water year .............. 27

11. - -Monthly instantaneous constituent concentrations during base flow, $1984-85$ water years ........ 30

12. - Relation between streamflow and acid-neutralizing capacity for three streams on Laurel Hill.

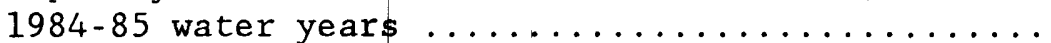

13. - Daily mean streamflow and weekly instantaneous $\mathrm{pH}$ at South Fork Bens Creek near Thomasdale,

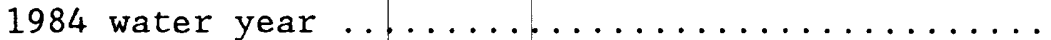

14. - -Daily mean streamflow and weekly instantaneous $\mathrm{pH}$ at North Fork Bens Creek at North Fork

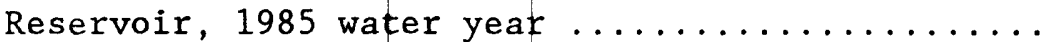

15.--Selected chemical-constituent net flux for 1984 water year, South Fork Bens Creek

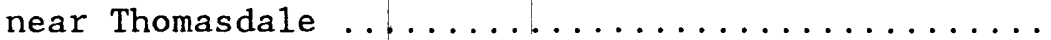

16.--Selected chemical-constituent net flux for 1984-85 water years, North Fork Bens Creek

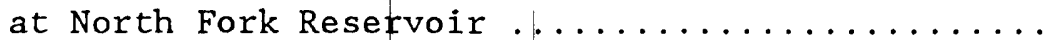

17.--Relation between streamflow and $\mathrm{pH}$ for the South Fork Bens Creek near Thomasdale ............ 41

18.--Relation between streamflow and $\mathrm{pH}$ for the North Fork Bens Creek at North Fork Reservoir ........ 41 
Figure 19.--Chemical changes in streamflow resulting from

inputs of:

19A.--Rainfal1 runoff November 10, 1983,

South Fork Bens Creek ............. 43

19B.--Snowme1t and rainfall runoff April 4-7,

1984, South Fork Bens Creek ............ 44

19C. - Rainfa11 runoff June 17-20, 1984,

South Fork Bens Creek ................ 44

19D. - Rainfal1 runoff March 29 to April 2, 1985,

South Fork Bens Creek ............. 45

19E. - Rainfal1 runoff May 2-3, 1985, South

Fork Bens Creek .................. 45

19F. - Rainfal1 runoff July 21-22, 1985,

South Fork Bens Creek ............. 46

19G.--Rainfal1 runoffs December 19-21 and 21-23, 1984, North Fork Bens Creek .......... 46

19H.--Snowme1t runoff February 22 to March 1 , 1985, North Fork Bens Creek .......... 47

19I.--Rainfal1 runoff March 12-13, 1985, North Fork Bens Creek ............ 47

19J. - -Rainfa11 runoff May 2-4, 1985, North Fork Bens Creek ............ 48

19K. - -Rainfa11 runoff July 8-9, 1985, North Fork Bens Creek ............. 48

19L. --Rainfal1 runoff November 26-28, 1985, North Fork Bens Creek .............. 49

19M. - Snowme1t runoff February 4-8, 1986, North Fork Bens Creek ................ 49

\section{TABLES}

Table

1.--Bedrock geology of study basins as a percentage of basin area .................... 7

2.--Laboratory analytical methods used for surfacewater and wet-deposition samples .......... 14

3.--Field analytical methods used for surface-water and wet-deposition samples ............. 14

4.--Results of precision observations for replicates .. 16

5.--Results of analyses of container blanks for filtered and dissolved constituents in deionized water .................... 16

6. --Results of analysis of container blanks for dissolved constituents in deionized water ..... 17

7.--Chemical data for precipitation samples from South Fork Bens Creek near Thomasdale, 1983-86 .. 
Table

8. --Volume-weighted mean $\mathrm{pH}$ and concentrations of major ions in precipitation at four monitoring stations in the northeastern part of the

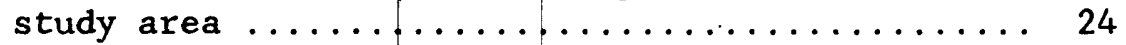

9.--Seasonal and annual input loads of major ions in precipitation at South Fork and North Fork Bens Creek watersheds .................. 25

10.--Volume-weighted mean concentrations of major ions and silica in precipitation and stream water, $1984-85$ water years . . . . . . . . . . 32

11.--Month1y water-budget estimates for the 1984-85 water years at the Bens Creek sites ........ 37

12.--Summary of annual input and output flux for precipitation and streamflow at South Fork Bens Creek in 1984 water year ............ 38

13.--Summary of annual input and output flux for precipitation and streamflow at North Fork Bens Creek in 1984-85 water years .......... 39

14. - Water-quality data for rainfall and snowmelt runoff at South Fork Bens Creek near

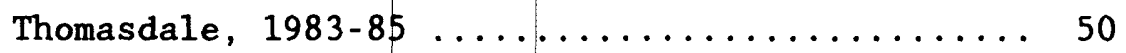

15. - Water-quality data for rainfall and snowmelt runoff at North Fork Bens Creek at North Fork

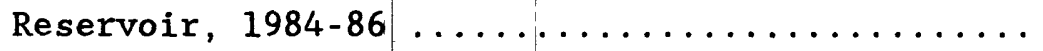


For the convenience of readers who may prefer inch-pound units rather than the metric (International System) units in this report, the following conversion factors may be used:

\section{Multiply Metric Unit}

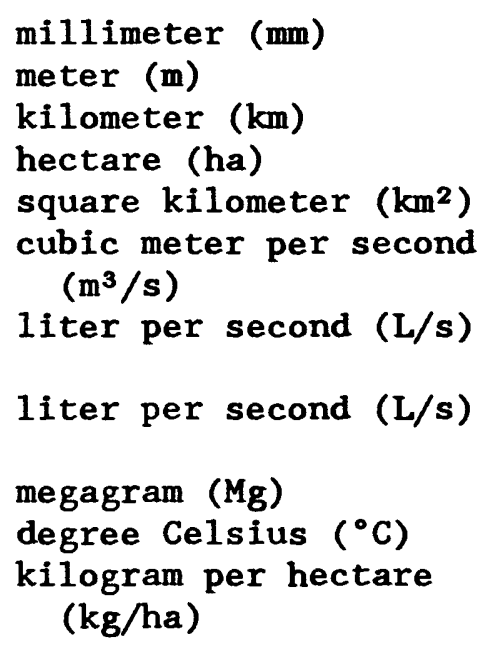

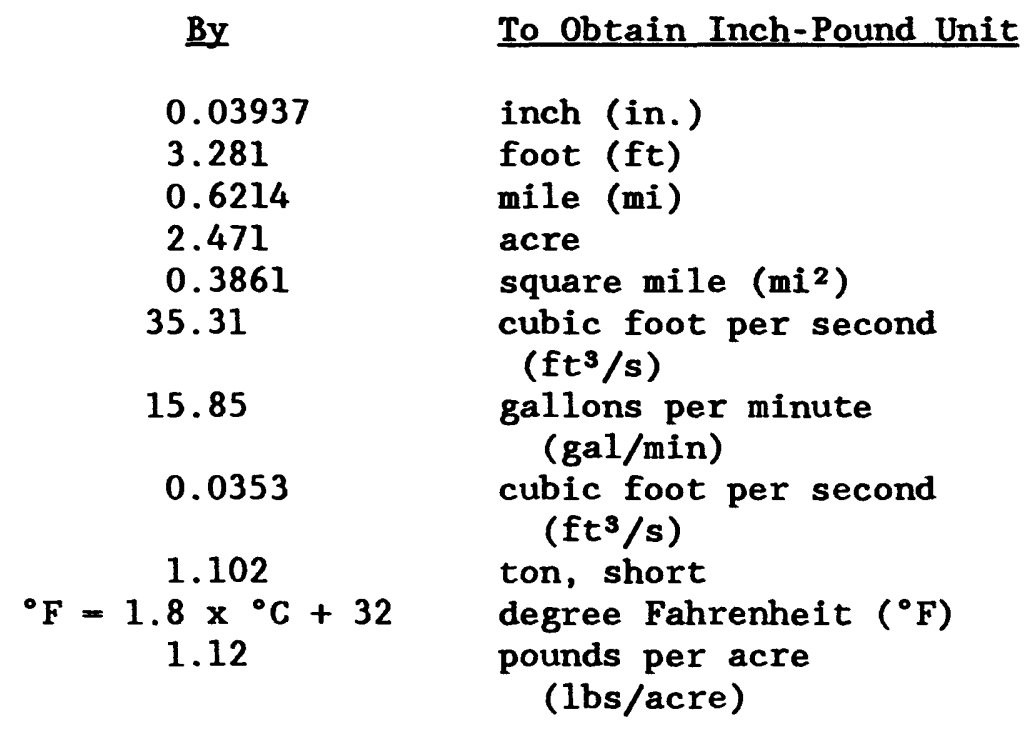

\section{Other Abbreviations}

Sea leve1: In this report, "sea level" refers to the National Geodetic Vertical Datum of 1929 (NGVD of 1929)--a geodetic datum derived from a general adjustment of the first-order level nets of both the United States and Canada, formerly called "Sea Level Datum of 1929". 


\title{
EFFECTS OF ACIDIC PRECIPITATION ON THE WATER QUALITY OF STREAMS IN THE LAUREL HILL AREA, SOMERSET COUNTY, PENNSYLVANIA, 1983-86
}

By James L. Barker and Emitt $C$. Witt III

\begin{abstract}
Five headwater streams in the Laurel Hill area in southwestern Pennsylvania were investigated from September 1983 through February 1986 to determine possible effects of acidic precipitation on water quality. Precipitation in the Laurel Hill area is among the most acidic in the Nation, with a mean volume-weighted $\mathrm{pH}$ of 4.06. Sulfate is the dominant acid-forming anion, averaging 3.6 milligrams per liter or about 50 kilograms per hectare in wet deposition alone. Nitrate averages about 2 milligrams per liter or 7 kilograms per hectare in the study area.

Stream chemistry in the five streams is quite variable and apparently is influenced to a large degree by the bedrock geology and by small amounts of alkaline material in watershed soils. Three of the five streams with no or little acid-neutralizing capacity presently are devoid of fish because of low $\mathrm{pH}$ and elevated aluminum concentrations. Aluminum concentrations increase in the other two streams during rainfall and snowmelt despite comparatively higher base flow and acid-neutralizing capacities.

Comparison of the chemistry of streamflow during 14 storm events at South Fork Bens Creek and North Fork Bens Creek reveals similar chemical responses when discharge suddenly increases. Concentrations of dissolved metals and sulfate increased during stormflow and snowmelt runoff, whereas concentrations of base cations, silica, and chloride decreased. Nitrate concentrations were not affected by rainfall runoff but tended to increase with snowmelt runoff.
\end{abstract}

\section{INTRODUCTION}

\section{Background}

In response to the Acid Precipitation Act of 1980, surface-water monitoring studies have been conducted jointly by the U.S. Geological Survey and the U.S. Environmental Protection Agency (USEPA) in areas of the country sensitive to acidification from atmospheric deposition. These studies are a major activity of the Aquatic Effects Task Group of the National Acid Precipitation Assessment Program (NAPAP).

The Aquatic Effects Task Group has established a network of long-term monitoring stations at lakes and streams across the country to correlate changes in deposition and surface-water quality. It is intended that such a network will improve the ability to detect and measure changes in stream chemistry over time. As part of the network, five headwater streams on the 
eastern slope of Laurel Hill in Somerset County, Pennsylvania, were selected to document the effects of acidic atmospheric loading on a watershed system and to compare them with the effects observed in other parts of the country. Quantification of the effects of the current loading rate on these and other sensitive areas is expected to provide information necessary for regulatory agencies to formulate guidelines for acceptable atmospheric loading rates of acidic materials.

The Laurel Hill area was selected because the precipitation there has mean volume-weighted $\mathrm{pH}$ of 4.06 , which is about 35 times more acidic than "pure rain" ( $\mathrm{pH}, 5.6)$. In addition, Laurel Hill soils are formed principally in materials weathered from noncarbonate sedimentary rocks that are highly sensitive to acidification.

A study of 61 headwater streams in the Laurel Hill area by Sharpe and others (1983) shows that 10 streams, or 16 percent, lacked fish. The acidic condition and lack of fish are attributed to acid deposition. The researchers found that all streams devoid of fish had low $\mathrm{pH}$, low acid-neutralizing capacity, and elevated concentrations of dissolved aluminum.

\section{Purpose and Scope}

This report describes results of an investigation to quantify the effects of present atmospheric-deposition levels on the water quality of streams within the Allegheny Mountains of southwestern Pennsylvania. The scope of this report is limited to the presentation and discussion of physical and chemical data collected from October 1983 through February 1986 at five firstand second-order watersheds of less than $10.4 \mathrm{~km}^{2}$ (square kilometers). Discussions of the following are included: (1) precipitation quantity and chemical quality; (2) pre- and post-episodic observations of stream constituents; ( 3 ) dissolved-constituent response during episodic discharge; and (4) yearly chemical budgets for sulfate, nitrate, base cations, and chloride. All runoff data are listed at the end of the report. Monthly water-quality data for the five study streams and daily discharge data for the two primary streams are published in U.S. Geological Survey Water-Data Reports PA-84-3 and PA-85-3 (U.S. Geological Survey, 1985-86) and are not reproduced in this report.

\section{Regiona1 Characteristics}

The study area is on the eastern slope of the Laurel Hill area of the Allegheny Mountains in northwest Somerset County, Pennsylvania near Johnstown in Cambria County (fig. 1). Five headwater streams with low acid-neutralizing capacity were included in the study. Two primary streams--South Fork Bens Creek and North Fork Bens Creek--and three satellite streams--North Branch Quemahoning Creek, Garys Run, and Cole Run--were sampled monthly to obtain background chemistry data. The two primary streams were also sampled for the dose/response phase of the study.

All five watersheds are within the mixed mesophytic forest region of Pennsylvania, but the watersheds also contain forest types dominated by beechmaple, northern hardwood, and oak-chestnut. There is mich local species diversification because of differences in soil depth, soil moisture, 
elevation, and microclimate. The area was logged in the late $1880^{\prime} \mathrm{s}$ and early $1900^{\prime} \mathrm{s}$, and the present-day forest is mostly second- and third-growth timber. Other cultural effects in all five basins have been minimal except for the construction of two small retention dams and an installation of a test well on South Fork Bens Creek. The watersheds have never been mined for coal.

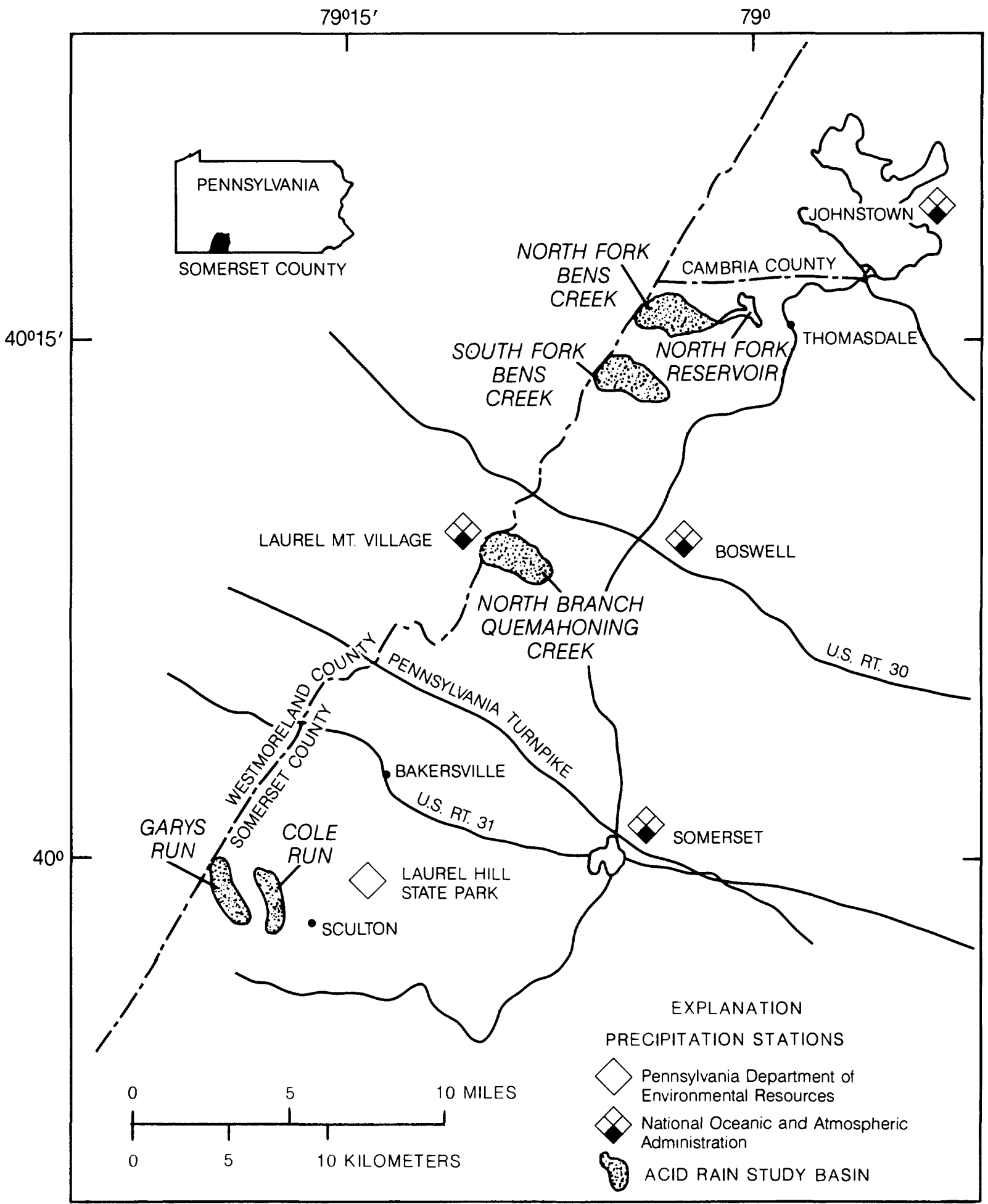

Figure 1.--Location of study basins and precipitation stations. 


\section{Climate and Air Quality}

The climate of Laurel Hill is a continental type, but temperatures are more variable and precipitation more frequent than in other parts of the State. The average annual precipitation is $1,350 \mathrm{~mm}$ (millimeters), and precipitation is distributed evenly throughout the year. The average annual snowfall is $1,680 \mathrm{~mm} / \mathrm{yr}$ (millimeters per year), and $510 \mathrm{~mm} / \mathrm{yr}$ or more in a single storm is not uncommon. Summer thunderstorms occur on about 35 days per year and produce frequent, brief showers of $13 \mathrm{~mm}$ or more (U.S. Department of Agriculture, 1983).

National Oceanic and Atmospheric Administration (NOAA) meterological stations relevant to the study area are at Johnstown, Boswell, Laurel Mt. Village, and Somerset (fig. 1). Data for freeze periods were collected at Laurel Mt. Village, about $11.3 \mathrm{~km}$ (kilometers) south of the South Fork Bens Creek study area. The period of ice for the 1984 water year ${ }^{1}$ was December 21 to February 15, and for the 1985 water year it was January 15-23 and February 5-13.

Most weather and, therefore, atmospheric chemicals and particulate matter in the study area are transported from regions west and southwest of Somerset County. Figure 2 shows emission densities of sulfur dioxide in Pennsylvania counties (Pennsylvania Department of Environmental Resources, 1982). Sulfur dioxide is emitted in the counties to the west and southwest of Somerset County. Therefore, rainfall in the study area would be expected to have elevated sulfate concentrations during most times.

A contour map of the volume-weighted annual mean $\mathrm{pH}$ of wet deposition, generated from data collected during 1985 (fig. 3), shows that Laurel Hill is within the area of the nation's most acidic wet deposition. The $\mathrm{pH}$ of the wet deposition collected in the South Fork Bens Creek watershed during 1983-85 had a mean of about 4.06, which is significantly lower than the value of 4.22 reported by Likens (1976). Similar pH values have been reported by the Pennsylvania State University/Pennsylvania Department of Environmental Resources (PSU/PaDER) for the precipitation at Laurel Hill State Park, about $29 \mathrm{~km}$ southwest of the Bens Creek study area. Data show that $\mathrm{pH}$ during January through December 1984 had a mean of 4.15 and ranged from 3.70 to 5.13 (Lynch, J.A., Pennsylvania State University, written commun., 1985).

1Water year is the period October 1 through September 30 and is designated by the calendar year in which it ends. 


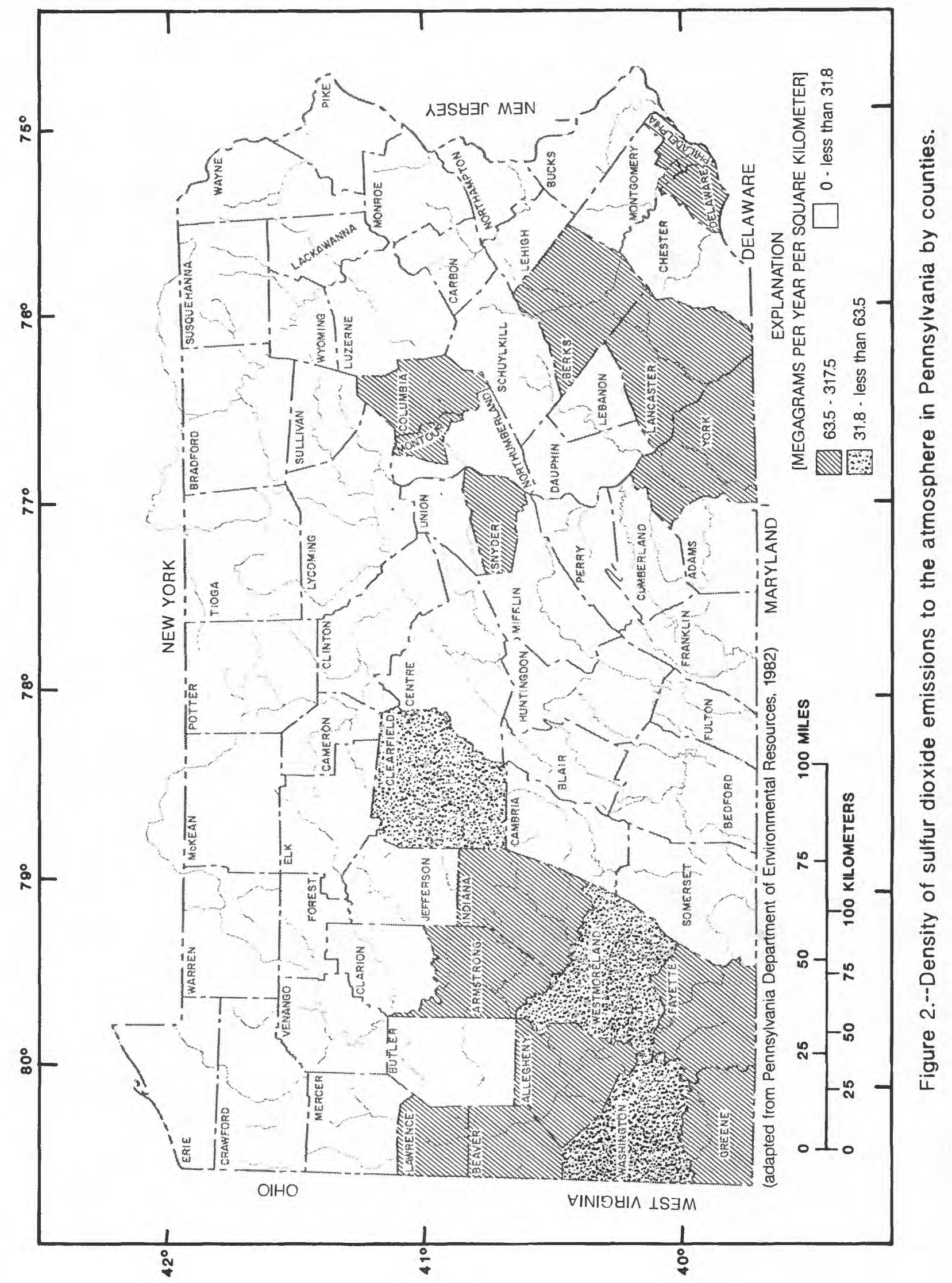



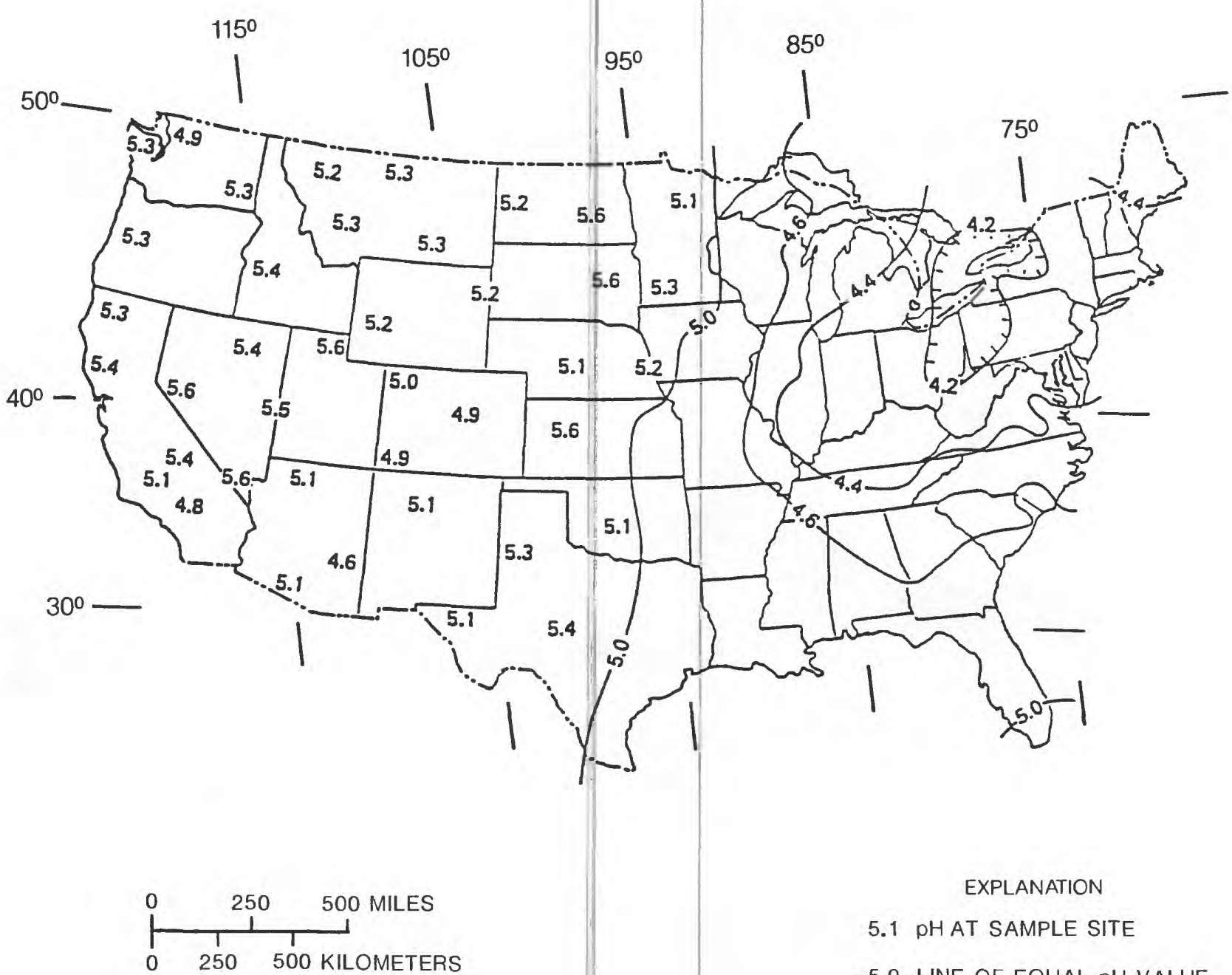

$5.1 \mathrm{pHAT}$ SAMPLE SITE

-5.0- LINE OF EQUAL pH VALUE

Figure 3.--pH of wet deposition (annual volume-weighted average) in the United States. Based on National Acid Precipitation Assessment Program and National Trends Network data (modified from U.S. Geological Survey 1985, fig. D-1). 
Laurel Hill lies within the Allegheny Mountain section of the Appalachian Plateau physiographic province. It is an anticlinal mountain that is oriented in a northeast-southwest direction; its strike or ridge line slopes slightly to the southwest, and its dip across the rock layers is about $5^{\circ} 30^{\prime}$ near the crest of the ridge (DeWalle and others, 1982).

Sedimentary rocks of Pennsylvanian and Mississippian ages are exposed on Laurel Hill. Figure 4 shows the geology of each of the study basins. The Pennsylvanian age rocks, from youngest to oldest, are the Allegheny and the Pottsville Groups. The Mississippian and Devonian rocks, from youngest to oldest, are the Mauch Chunk Formation, the Loyalhanna Limestone, the Burgoon Sandstone, and the Shenango through Oswayo Formations, undivided. The Loyalhanna Limestone is highly compressed and discontinuous in the northern part of Somerset County (Flint, 1965). The Burgoon through Oswayo rocks are equivalent to the Pocono Group.

Exposed Mississippian-age rocks are older in the northern part of the anticlinal ridge ( $f i g .5 A$ ) than in the southern part (fig. 5B) because of differential erosion of the ridge top. The extent of exposure of the various rock units is important because the Loyalhanna Limestone, which may possibly underlie the Mauch Chunk Formation, is a source of base cations that increase stream $\mathrm{pH}$ and buffering capacity. On the other hand, the Allegheny Formation is a source of hydrogen ions that increase acidity in streams.

The percentages of the rock formations within the study basins are 1 isted in table 1. The degree of acidification of surface water is linked to the geology and exposure of rock types in the watershed. Therefore, the local variation in geology may limit the transfer value of information on sensitivity of watersheds to acidification. The importance of basin hydrogeology to the sensitivity to acidification and the presence of trout populations on Laurel Hill has been extensively investigated by DeWalle and others (1987) and Sharpe and others (1987).

Table 1.--Bedrock geology of study basins as a percentage of basin area

\begin{tabular}{|c|c|c|c|c|c|c|c|}
\hline Basin & $\begin{array}{l}\text { Shenango } \\
\text { Formation }\end{array}$ & $\begin{array}{l}\text { Burgoon } \\
\text { Sandstone }\end{array}$ & $\begin{array}{l}\text { Mauch Chunk } \\
\text { Formation }\end{array}$ & $\begin{array}{l}\text { Pottsville } \\
\text { Formation }\end{array}$ & $\begin{array}{l}\text { Allegheny } \\
\text { Formation }\end{array}$ & $\begin{array}{l}\text { Glenshaw } \\
\text { Formation }\end{array}$ & Total \\
\hline $\begin{array}{l}\text { South Fork Bens } \mathrm{Cr} \text {. } \\
\text { North Fork Bens } \mathrm{Cr} \text {. } \\
\text { North Branch } \\
\text { Ouemahoning } \mathrm{Cr}\end{array}$ & 3 & $\begin{array}{l}62 \\
29\end{array}$ & $\begin{array}{l}14 \\
22\end{array}$ & $\begin{array}{l}12 \\
33 \\
34\end{array}$ & $\begin{array}{r}6 \\
15 \\
66\end{array}$ & $\begin{array}{l}3 \\
1\end{array}$ & $\begin{array}{l}100 \\
100 \\
100\end{array}$ \\
\hline $\begin{array}{l}\text { Cole Run } \\
\text { Garys Run }\end{array}$ & & & $1 \frac{1}{12}$ & $\begin{array}{l}23 \\
79\end{array}$ & $\begin{array}{r}76 \\
9\end{array}$ & & $\begin{array}{l}100 \\
100\end{array}$ \\
\hline
\end{tabular}




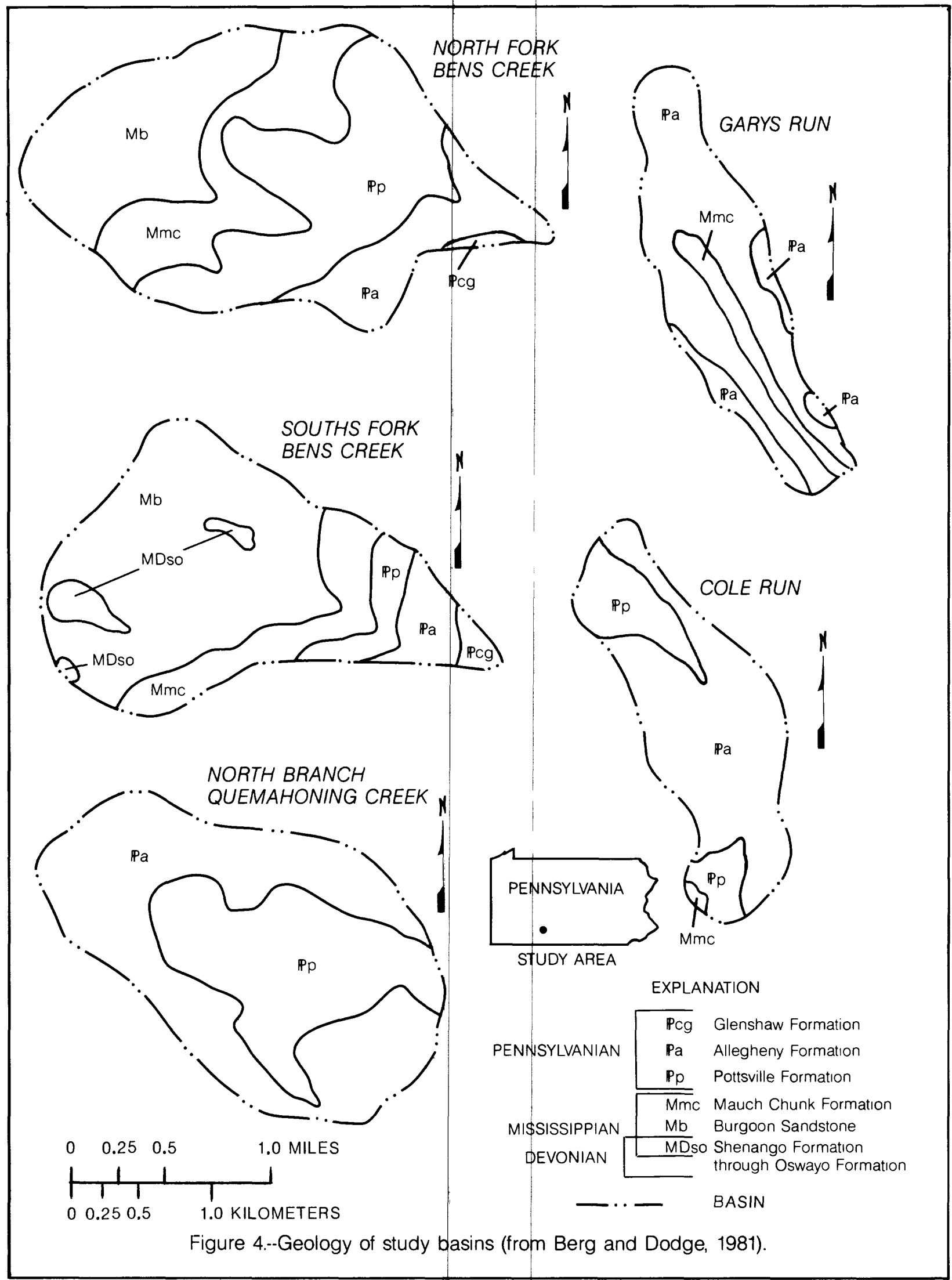




\section{A - NORTH FORK BENS CREEK}

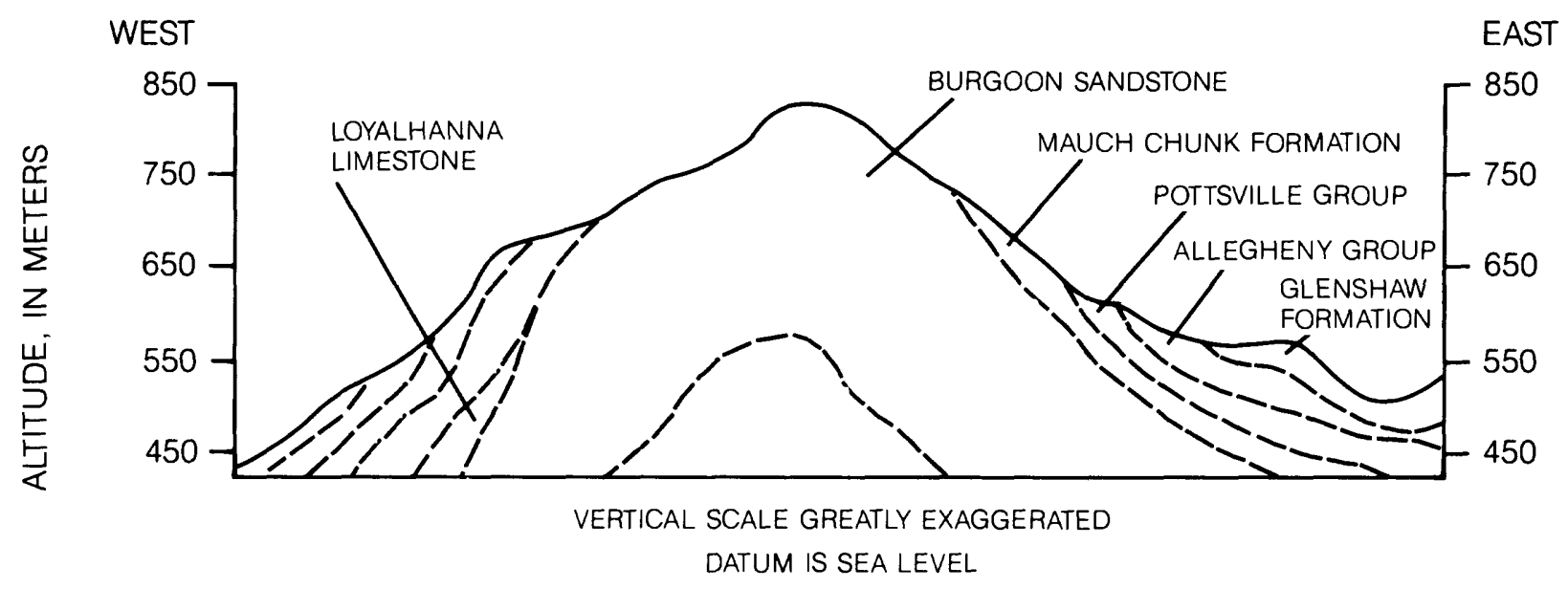

B - GARYS RUN

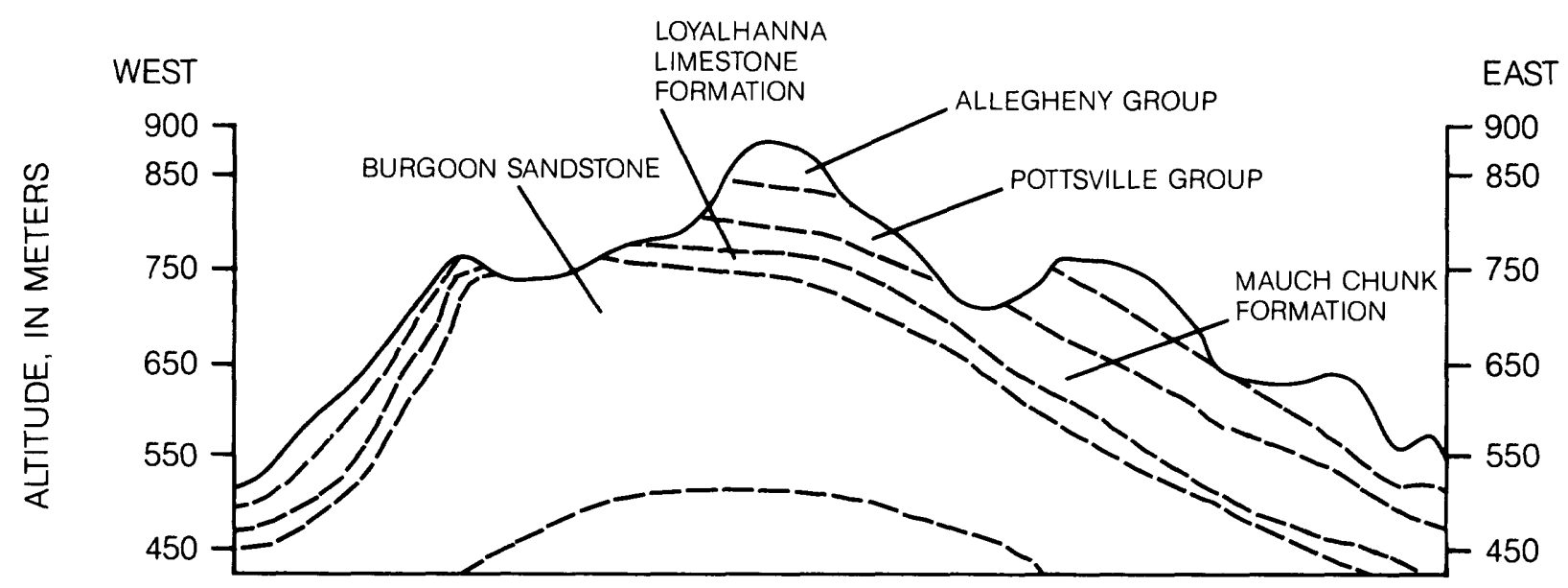

VERTICAL SCALE GREATLY EXAGGERATED DATUM IS SEA LEVEL

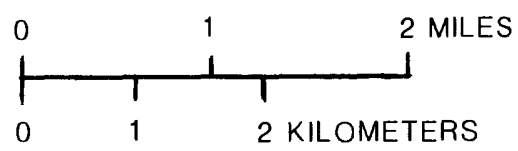

Figure 5.--Generalized geologic sections of Laurel Hill anticline in the vicinity of: A. North Fork Bens Creek; B. Garys Run. 
Four soil series--Hazleton, Rayne-Gilpin, Cookport, and Ernest--are the dominant soils in the study watersheds. These soils are silt loams to very stony silt loams that are typically acidic ( $\mathrm{pH} 3.6$ to 5.5)1, moderately deep, and well drained (U.S. Department of Agriculture, 1983). Detailed soil maps for each of the five watersheds and general information as to soil use, management, physical and chemical properties, and factors of soil formation are contained in the Soil Survey of Somerset County, Pennsylvania, (U.S. Department of Agriculture, 1983).

\section{Site Descriptions}

North Fork Bens Creek, South Fork Bens Creek, North Branch Quemahoning Creek, Garys Run, and Cole Run were selected for monthly chemical sampling to obtain background data on temporal variability of streams in the area. Two streams--South Fork Bens Creek and North Fork Bens Creek--were selected as primary sites and as such received additional sampling during storm and snowmelt runoff to determine the effects of rapidly changing streamflows.

\section{North Fork Bens Creek at North Fork Reservoir}

The site is located at 1 at $40^{\circ} 15^{\circ} 58^{\prime \prime N}$., 1ong $79^{\circ} 01^{\prime} 01^{\prime \prime W}$. in northwestern Somerset County and is at the inlet to North Fork Reservoir $12.1 \mathrm{~km}$ southwest of Johnstown (fig. 1). The sampling site is on a second-order stream, which has a drainage area of $8.94 \mathrm{~km}^{2}$. The watershed, at an elevation of 407 to 833 $\mathrm{m}$ (meters) above sea level, is nearly all forested and under the ownership and protection of the Greater Johnstown Municipal Authority.

Beginning with the autumn of 1984, this site was included in the dose/response phase of the study and designated a primary site, along with the South Fork Bens Creek site. As such, the two watersheds had the same types of equipment for continuously recording stage, automatically sampling the stream, and recording rain.

The upper half of the watershed is underlain by the Mississippian sandstones of the Burgoon Sandstone and Mauch Chunk Formation and the lower half by the Pennsylvanian sandstones of the Pottsville and Glenshaw Formations. The Loyalhanna Limestone, which is about $15 \mathrm{~m}$ thick in southern Somerset County, shows regional thinning trending northeastward to almost a complete disappearance at the approximate latitude of the Bens Creek watershed (F1int, 1965). The watershed contains no coal mines but at least one exploratory gas wel1. Soils are predominantly Hazleton, Ernest, and RayneGilpin loams.

\footnotetext{
${ }^{1}$ Soil $\mathrm{pH}$ is determined in the laboratory from an equilibrium solution of soil sample and distilled water at atmospheric pressure and temperature.
} 
This primary site is located at lat $40^{\circ} 13^{\prime} 41^{\prime \prime N}$., long $79^{\circ} 02 \cdot 49^{\prime \prime} \mathrm{W}$. and is $12.6 \mathrm{~km}$ southwest of Johnstown (fig. 1). The sampling site is in a forested area on a second-order stream. The watershed has a drainage area of $8.50 \mathrm{~km}^{2}$ and is at an elevation of between 505 and $884 \mathrm{~m}$. Flow is regulated partially by two small dams having a combined capacity of $32,929.5 \mathrm{~m}^{3}$ (cubic meters). Daily diversion of about $1,037 \mathrm{~m}^{3}$ is metered by the Conemaugh Township Municipal Authority.

The upper 79 percent of the watershed is underlain by the Mississipian sandstones of the Burgoon Sandstone and Mauch Chunk Formation, and the lower 21 percent by Pennsylvanian sandstones of the Pottsville and Allegheny Formations. Basin soils consist primarily of shallow Hazleton very stony, sandy loam in the uplands and Cookport loam in the foothills.

Water quality of the South Fork Bens Creek was affected by artesian flow from a test well drilled by the Municipal Authority into the Burgoon Sandstone at about the center of the basin. Test well drilling began on October 10, 1984, and was completed as a $203 \mathrm{~mm}$ diameter hole, $54 \mathrm{~m}$ deep, with $11 \mathrm{~m}$ of bottom grouted casing. The total flow yield of the well was measured at 75 L/s (1iters per second), (R. Casselberry, Meiser and Ear1, Hydrogeologists, written commun., 1985). The well continued flowing at a rate of about $2.5 \mathrm{~L} / \mathrm{s}$ until January 10,1985, when it was capped. During the time water was flowing from the well, it had the effect of raising the stream $\mathrm{pH}$, alkalinity, and specific conductance. The resulting effect on the stream water quality was such that the interpretive value of the stream was compromised and the study emphasis was transferred to North Fork Bens Creek in October 1984.

Grab samples of the overflow from the "test" well indicated the water quality generally is excellent, ( $R$. Casselberry, Meiser and Earl, Hydrogeologists, written commun., 1985). A private laboratory analysis of an unfiltered sample collected on December 13, 1984, showed the following:
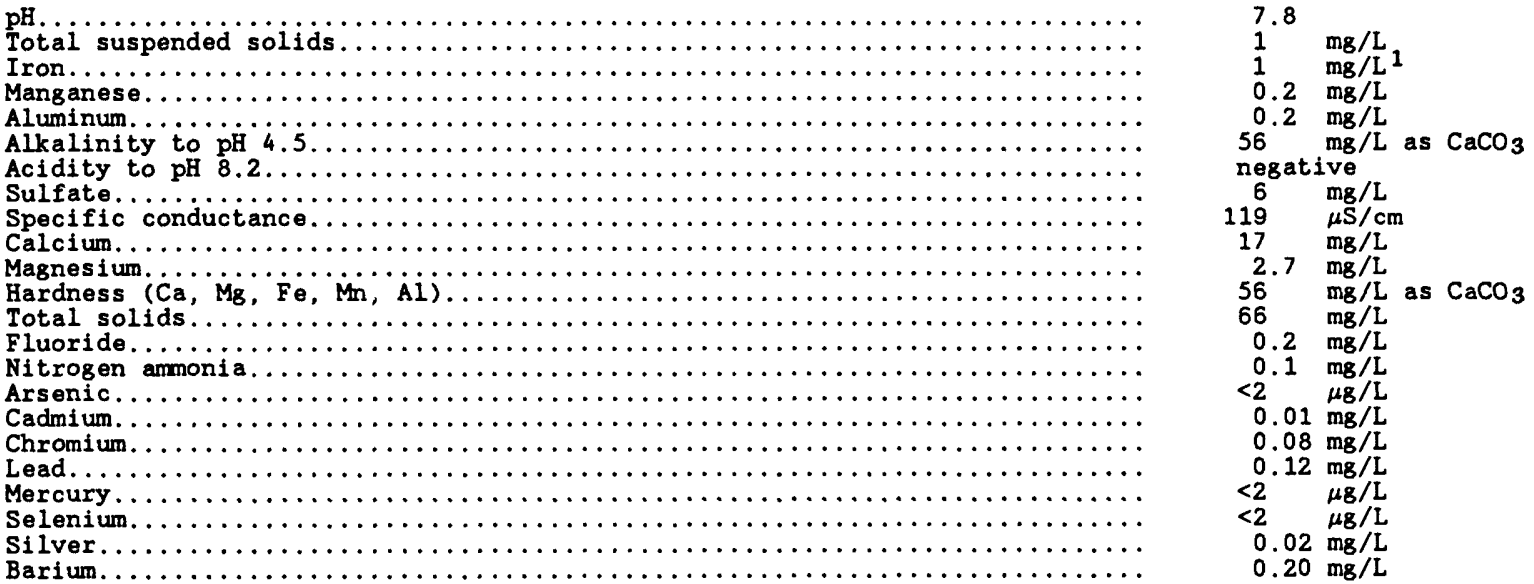

1 Filtered analysis produced a dissolved-iron concentration of $0.13 \mathrm{mg} / \mathrm{L}$. 
North Branch Quemahoning Creek at Roytown

This satellite site is located at lat $40^{\circ} 06^{\prime} 38^{\prime \prime N} \mathrm{~N}$, long $79^{\circ} 08^{\prime} 41^{\prime \prime} \mathrm{W}$. in northwestern Somerset County and is about $19 \mathrm{~km}$ northwest of Somerset and $8 \mathrm{~km}$ north of Bakersville (fig. 1). This and all selected satellite sites were sampled monthly for major ions, dissolved metals, temperature, pH, specific conductance, alkalinity, and streamflow. The sampling site is on a secondorder stream in a watershed that is almost entirely forested. The drainage area is $6.89 \mathrm{~km}^{2}$.

The watershed is underlain entirely by Pennsylvanian sandstones of the Pottsville and Allegheny Formations. Soils series developed on the material consists of the Hazleton and Cookport sandy and silt loams.

\section{Garys Run near Barronvale}

This satellite site is located at lat $39^{\circ} 58^{\prime} 25^{\prime \prime N}$., long $79^{\circ} 17^{\prime} 51^{\prime \prime} \mathrm{W}$. in west-central Somerset County and is about $20.1 \mathrm{~km}$ southwest of Somerset and $4.8 \mathrm{~km}$ north of Sculton (fig. 1). The sampling site is on a first order stream; the drainage area is $3.16 \mathrm{~km}^{2}$. The watershed is entirely on state forest lands and is forest covered except for about $0.80 \mathrm{~km}^{2}$ that was recently disturbed by clear-cut logging. The logged area does not affect stream quality except during periods of overland runoff.

Basin soils are predominantly of the Ernest and Rayne-Gilpin Series of sandy loams. Pennsylvanian sandstones of the Pottsville and Allegheny Formations dominate the geology. About 12 percent of the parent material is Mississippian sandstone of the Mauch Chunk Formation.

\section{Cole Run near Barronvale}

This satel1ite site is located at lat $39^{\circ} 58^{\prime} 00^{\prime \prime} \mathrm{N} .$, long $79^{\circ} 17^{\prime} 25^{\prime \prime} \mathrm{W}$. in west central Somerset County and is about $17.4 \mathrm{~km}$ southwest of Somerset and $3.2 \mathrm{~km}$ north of Sculton (fig. 1). The sampling site is on a first order stream; the drainage area is $4.30 \mathrm{~km}^{2}$. The watershed is completely forest covered and is within state forest boundaries.

The bedrock geology is nearly all Pennsylvanian sandstone of the Pottsville and Allegheny Formations. Although many soil series are represented, the Cookport, Hazleton, Ernest, and Rayne-Gilpin Series predominate. 


\section{METHODS OF STUDY}

\section{Data Collection}

Methods of data collection, sample handling, and sample preservation were in accordance with the "Working Protocol" established in 1982 and revised in March 1985 by the ad hoc committee for Aquatic Effects Task Group $E$ and the USEPA long-term surface water monitoring program.

Base flow was sampled monthly at each stream by collecting a grab sample at the centroid of flow. At the two primary sites, storm events were sampled using an automatic water sampler that was activated by a rise in stream stage. The automatic sampler was programmed to collect as many as 24 discrete samples at variable time intervals so that the rise, peak, and recession of the streamflow would be represented.

Precipitation was measured and recorded at the South Fork and the North Fork Bens Creek sites by weighing-bucket gages. A11 precipitation measurements were referenced to an adjacent National Weather Service standard rain gage. Weekly and episodic wet deposition samples were collected for chemical analysis by a wet/dry collector in accordance with methods described in the National Atmospheric Deposition Program Instruction Manual (Bigelow, 1982).

Water stage in South Fork and North Fork Bens Creeks was monitored continuously by a gas-purge servomanometer attached to chart and digital recorders. Relations of stage to discharge were developed using standard U.S. Geological Survey methods (Rantz and others, 1982) for the primary stations. Instantaneous streamflow was measured at the three satellite sites at the time of chemical sampling.

\section{Sample Treatment and Analysis}

Stream, wet deposition, and QA/QC (quality assurance/quality contro1) samples were passed through filters of several different pore sizes during the course of the study. In the beginning of the project $0.45-\mu \mathrm{m}$ (micrometer) porosity nitrocellulose filters were used. Following a period of experimental filtering with $0.2-\mu \mathrm{m}$ and $0.1-\mu \mathrm{m}$ porosity between August and November 1984, all analyses for dissolved ions were filtered through $0.1-\mu \mathrm{m}$ polycarbonate filters and stored at $4.0^{\circ} \mathrm{C}$ (degrees Celsius) until analysis for dissolved ions. In addition, samples for cation analysis were acidified with $1-\mathrm{N}$ ultrapure nitric acid to $\mathrm{pH} 2$ or less prior to storing. Samples for dissolved organic carbon (DOC) were passed through $0.4-\mu \mathrm{m}$ silver filters and chilled at $4.0^{\circ} \mathrm{C}$ until analysis. Filtered samples were packed in ice and shipped to the U.S. Geological Survey Central Laboratory in Arvada, Colorado, for analyses using methods described in table 2 for low-ionic-strength solutions.

Values for several properties of streamflow and precipitation were measured in the field as samples were being collected. The properties and methods of field analysis are listed in table 3. 
Table 2.--Laboratory analytical methods used for surface-water and, wet-deposition samples

[Reporting level in milligrams per liter except as noted]

\begin{tabular}{|c|c|c|c|}
\hline Chemical constituent & Anafytical & method & $\begin{array}{r}\text { Limit of } \\
\text { detection }\end{array}$ \\
\hline $\begin{array}{l}\text { Acidity as }\left[\mathrm{H}^{+}\right] \\
\text {Acid neutralizing capacity }\end{array}$ & $\begin{array}{l}\text { Electrometric } \\
\text { Electrometric } \\
\text { derivative }\end{array}$ & $\begin{array}{l}\text { titration } \\
\text { titration (second } \\
\text { ethod) }\end{array}$ & $\begin{array}{c}0.01 \\
.5\end{array}$ \\
\hline $\begin{array}{l}\text { Aluminum, dissolved } \\
\text { Calcium, dissolved }\end{array}$ & $\begin{array}{l}\text { Atomic-absorpt } \\
\text { Atomic-absorpt }\end{array}$ & $\begin{array}{l}\text { ion spectroscopy } \\
\text { ion spectroscopy }\end{array}$ & $\begin{array}{l}.05 \\
.005\end{array}$ \\
\hline Hardness, dissolved & Complexometric & & 1 \\
\hline Bromide, dissolved & Ion chromatogr & aphy & .01 \\
\hline Chloride, dissolved & Ion chromatogr & aphy & .01 \\
\hline Fluoride, dissolved & Ion chromatogr & aphy & .01 \\
\hline Nitrate, dissolved & Ion chromatogr & aphy & .01 \\
\hline Sulfate, dissolved & Ion chromatogr & aphy & .01 \\
\hline Iron, dissolved & Atomic-absorpt & ion spectroscopy & 2 \\
\hline Magnesium, dissolved & Atomic-absorpt & fion spectroscopy & .01 \\
\hline Manganese, dissolved & Atomic-absorpt & ion spectroscopy & 0.2 \\
\hline $\mathrm{pH}$ & Electronetric & titration & .1 units \\
\hline Potassium, dissolved & Atomic-absorpt & ion spectroscopy & .01 \\
\hline Silica, dissolved & Atomic-absorpt & ion spectroscopy & .01 \\
\hline $\begin{array}{l}\text { Sodium, dissolved } \\
1 \mu \mathrm{S} / \mathrm{cm}\end{array}$ & Atomic-absorpt & ion spectroscopy & .01 \\
\hline $\begin{array}{l}\text { Carbon, organic, dissolved } \\
\text { Nitrogen ammonia as } \mathrm{N}, \\
\text { dissolved }\end{array}$ & $\begin{array}{l}\text { Wet oxidation } \\
\text { Block digest } p\end{array}$ & lus colorimetry & 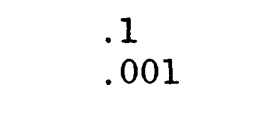 \\
\hline $\begin{array}{l}\text { Phosphate ortho - P, } \\
\text { dissolved }\end{array}$ & Colorimetry, pl & hosphomolybdate & .001 \\
\hline
\end{tabular}

Table 3.--Field analytical methods used for surface-water and wet-deposition samples

\begin{tabular}{|c|c|c|}
\hline Constituent & & Analytical method \\
\hline $\begin{array}{l}\text { Acidity } \\
\text { Acid-neutralizing capacity, } \\
\quad \text { total as } \mathrm{CaCO}_{3} \\
\text { Temperature } \\
\text { Specific conductance } \\
\text { pH } \\
\text { Discharge }\end{array}$ & & $\begin{array}{l}\text { Gran method (Gran, 1952) } \\
\text { Gran method (Gran, 1952) } \\
\text { Thermometer NBS* } \\
\text { Wheatstone bridge } \\
\text { Combination electrode } \\
\text { Current meter (Rantz, 1982) }\end{array}$ \\
\hline *National Bureau Standards & 14 & \\
\hline
\end{tabular}




\section{Quality Assurance}

Quality assurance was an integral part of the sampling program throughout the study. Initially, quality assurance was done randomly, but became part of the monthly and storm event sampling program in February 1985 with the issuance of the USEPA QA/QC guidelines contained in the "Working Protocol" for the long-term monitoring program.

The QA/QC program consisted of replicate samples, filtration blanks, and container blanks to be taken at one primary stream site each time that site is sampled. In addition, replicates were to be obtained on two secondary streams three times yearly under low, intermediate, and high flow conditions. Audit or spiked samples were provided three times per year by an independent contractor to USEPA to determine interlaboratory bias and comparability among projects.

Precision data were generated by analyzing samples in duplicate. Differences between the two values were multiplied by 0.89 to approximate the standard deviation (Aquatic Effects Task Group, 1985). The standard deviation divided by the mean of the duplicate values and multiplied by 100 yielded the relative standard deviation (RSD), in percent.

Filtration and container blanks were prepared in the field and submitted to the laboratory to be analyzed with the routine samples. The blanks were analyzed to determine the adequacy of the filtration manipulation, the cleanliness of the linear-polyethylene dissolved-ion sample container, and purity of the deionized water (tables 4-6). Precision observations for chloride, phosphate, nitrate, and sulfate had average RSD values less than the objective precision value. Average RSD values for all other constituents were above the precision objectives. Filtration blanks generally confirmed the acceptability of the membrane procedure for dissolved constituents. Although few observations were less than detection limits, nearly all concentrations were within expected and acceptable ranges. The mean concentrations of sulfate, aluminum, iron, and manganese are of marginal utility because of one or two relatively high values that raised the mean. Container blanks confirmed the adequacy of the container and purity of the deionized water. Audit sample results are incomplete and not reported here but are available from the USEPA, Environmental Research Laboratory, Corvaliis, Oregon. 
Table 4.--Results of laboratory precision observations for replicates

\begin{tabular}{|c|c|c|c|c|c|}
\hline \multirow{2}{*}{$\begin{array}{l}\text { Constituent } \\
\text { Aluminum }\end{array}$} & \multirow{2}{*}{$\begin{array}{l}\text { Number of } \\
\text { replicate } \\
\text { analyses }\end{array}$} & \multicolumn{2}{|c|}{$\begin{array}{l}\text { Range of } \\
\text { RSD }^{1} \text { values } \\
\text { (percent) }\end{array}$} & \multirow{2}{*}{$\begin{array}{c}\begin{array}{c}\text { Average } \\
\text { RSD } \\
\text { (percent) }\end{array} \\
16.4\end{array}$} & \multirow{2}{*}{$\begin{array}{c}\begin{array}{c}\text { Intralab relative } \\
\text { precision goal2 } \\
\text { (percent) }\end{array} \\
10\end{array}$} \\
\hline & & 3.6 & to 33 & & \\
\hline Calcium & 9 & 0 & to 18 & 8.7 & 5 \\
\hline Magnesium & 9 & 0 & to 73 & 16.6 & 5 \\
\hline Sodium & 9 & 0 & to 62 & 7.8 & 5 \\
\hline Potassium & 9 & 0 & to 62 & 14 & 5 \\
\hline Fluoride & 9 & 0 & to 101 & 26.8 & 5 \\
\hline Chloride & 9 & 0 & to 3 & 1.1 & 5 \\
\hline Phosphate & 9 & 0 & to 19 & 2.1 & 10 \\
\hline Nitrate & 9 & 0 & to 23 & 4.8 & 10 \\
\hline Sulfate & 9 & 0 & to 10 & 2 & 5 \\
\hline
\end{tabular}

${ }^{1}$ RSD $=$ relative standard deviation--

RSD (in percent) $=\frac{\text { Standard Deviation }}{\text { Mean }} \times 100$

2Intralab relative precision goal is the precision at concentrations about 10 times instrument detection limits.

Table 5.--Results of analyses of container blanks for filtered and dissolved constituents in deionized water

[mg/L, milligrams per liter; $\mu / L$, micrograms per liter; $<$, less than]

\begin{tabular}{|c|c|c|c|c|}
\hline $\begin{array}{l}\text { Dissolved } \\
\text { constituent }\end{array}$ & $\begin{array}{l}\text { umber of } \\
\text { bservations }\end{array}$ & $\begin{array}{l}\text { Number of } \\
\text { observations } \\
\text { less than } \\
\text { detection limit }\end{array}$ & $\begin{array}{l}\text { Range of } \\
\text { values }\end{array}$ & $\begin{array}{l}\text { Estimated } \\
\text { average } \\
\text { concentration } 1\end{array}$ \\
\hline Calcium (mg/L) & 9 & 0 & 0.010 to 0.900 & 0.280 \\
\hline Magnesium (mg/L) & 9 & 0 & .009 to .200 & .060 \\
\hline Sodium (mg/L) & 9 & 3 & $<.050$ to .400 & .160 \\
\hline Potassium (mg/L) & 9 & 0 & .010 to & .070 \\
\hline Fluoride (mg/L) & 9 & 3 & $<.010$ to & .040 \\
\hline Chloride (mg/L) & 9 & 1 & $<.010$ to & .230 \\
\hline Phosphate (mg/L) & 9 & 7 & $<.001$ to & $<.001$ \\
\hline Nitrate $(\mathrm{mg} / \mathrm{L})$ & 9 & 6 & $<.001$ to .020 & $<.010$ \\
\hline Sulfate $(\mathrm{mg} / \mathrm{L})$ & 9 & 0 & .090 to 1.600 & .510 \\
\hline Aluminum $(\mu \mathrm{g} / \mathrm{L})$ & 9 & 2 & $<1.000$ to 20 & 11 \\
\hline Iron $(\mu \mathrm{g} / \mathrm{L})$ & 9 & 6 & $<2.000$ to 6.900 & 2.600 \\
\hline Manganese $(\mu \mathrm{g} / \mathrm{L})$ & 9 & 7 & $<1.000$ to 2.600 & 1.200 \\
\hline
\end{tabular}


Table 6.--Results of analysis of container blanks for dissolved constituents in deionized water

[mg/L, milligrams per liter; $\mu \mathrm{g} / \mathrm{L}$, micrograms per liter; <, less than; - - no detection limit; $\mu \mathrm{S} / \mathrm{cm}$, microsiemens per centimeter at 25 degrees Celsius]

\begin{tabular}{|c|c|c|c|c|c|}
\hline $\begin{array}{l}\text { Dissolved } \\
\text { constituent }\end{array}$ & $\begin{array}{l}\text { Number of } \\
\text { observations }\end{array}$ & $\begin{array}{l}\text { Number of } \\
\text { observations } \\
\text { less than } \\
\text { detection limit }\end{array}$ & Range & of & values \\
\hline $\mathrm{pH}$ (units) & 2 & -- & 5.60 & to & 5.80 \\
\hline $\begin{array}{l}\text { Alkalinity (mg/L as } \\
\text { calcium carbonate) }\end{array}$ & 2 & 0 & & & 2 \\
\hline $\begin{array}{l}\text { Specific conductance } \\
(\mu \mathrm{S} / \mathrm{cm})\end{array}$ & 2 & 0 & & & 1 \\
\hline Calcium (mg/L) & 2 & 2 & $<.02$ & to & $<.03$ \\
\hline Magnesium (mg/L) & 2 & 1 & $<.01$ & to & .04 \\
\hline Sodium (mg/L) & 2 & 2 & $<.2$ & & \\
\hline Potassium (mg/L) & 2 & 0 & .02 & to & .04 \\
\hline Chloride (mg/L) & 2 & 1 & .02 & to & $<.2$ \\
\hline Sulfate $(\mathrm{mg} / \mathrm{L})$ & 2 & 1 & .1 & to & $<.2$ \\
\hline Silica (mg/L) & 2 & 2 & & & 0 \\
\hline Nitrate $(\mathrm{mg} / \mathrm{L})$ & 1 & 1 & $<.05$ & & \\
\hline Phosphorus (mg/L) & 2 & 2 & $<.01$ & to & $<.06$ \\
\hline $\operatorname{Iron}(\mu \mathrm{g} / \mathrm{L})$ & 2 & 1 & $<3$ & to & 5 \\
\hline Manganese $(\mu \mathrm{g} / \mathrm{L})$ & 2 & 2 & & & $<1$ \\
\hline Aluminum $(\mu \mathrm{g} / \mathrm{L})$ & 2 & 1 & $<10$ & to & 20 \\
\hline Acidity $\left(\mathrm{H}^{+}\right)$ & 2 & 1 & $<.1$ & to & .3 \\
\hline Bromide (mg/L) & 2 & 2 & $<.01$ & to & .1 \\
\hline Fluoride $(\mathrm{mg} / \mathrm{L})$ & 2 & 1 & $<.01$ & to & .03 \\
\hline
\end{tabular}




\section{Data Interpretation}

The annual chemical budget or net flux for the major constituents was calculated for the 1984 and 1985 water year at North Fork Bens Creek and for the 1984 water year at South Fork Bens Creek. The 1985 chemical budgets for South Fork were not calculated because of the chemical changes as a result of the artesian flow of well water into the stream as described earlier. The 1984 chemical budgets for the North Fork were estimated from the South Fork precipitation data and streamflow-correlation analyses.

Because of the problems inherent in calculating mass balance over a 1 year period, using conservative materials, a method described by Galloway and others (1983) to calculate net flux as a running sum was used. The term "Running Net Flux" (RNF) is defined as

$$
\mathrm{RNF}=\Sigma\left(\begin{array}{cc}
\mathrm{n} & -0) \\
i & i
\end{array}\right.
$$

where $i$ is the time in weeks of observation, $n$ is the number of weeks, $I_{i}$ is the atmospheric deposition (input) of the element and ${ }_{{ }_{i}}$ is the stream discharge (output) of the element. The net flux, then, ${ }^{i}$ is equal to the weekly difference in the inputs and outputs of a constituent.

The running net flux (RNF) was then related to annual flux by the calculation of the "Retention Index" (RI), defined by Galloway and others (1983) as the ratio of the RNF value to the annual sum of input for each constituent. Mathematically,

$$
R I=\left.\frac{R N F}{\underset{i=1}{n}(\text { inputs) }}\right|_{i}
$$

The values of RI can range from 1 to $-\infty$. When $R I=1$, the input was completely retained in the watershed. When $R I=0$, input equaled output, and when $R I=-1$, input was $1 / 2$ output.

Data interpretation for stormflow data involves general plots of constituents with runoff hydrographs. Correlation and regression analysis of some constituents from both individual events and entire data sets were computed using the computer package, Statistical Analysis Systems (1979). Values for chemical constituents interpreted by correlation and regression methods were transformed into logarithms because water quality data typically are not normally distributed.

Annual atmospheric loading was calculated from weekly net deposition volumes and concentration data. Volume-weighted mean seasonal concentrations (see table 9) were substituted for weekly precipitation not analyzed. Annual stream loads were calculated from flow-duration curves and transport curves (Searcy, 1963; Porterfield, 1972) developed for each ion of interest. Concentration data are available for a range of monthly streamflows and for storm and snowmelt runoff events. 


\section{Precipitation}

\section{Quantity}

The annual precipitation at the South Fork Bens Creek gage was $1,482 \mathrm{~mm}$ and $1,049 \mathrm{~mm}$ for the 1984 and 1985 water years, respectively. The long-term average for the region is about $1,350 \mathrm{~mm}$ (National Oceanic and Atmospheric Administration, 1950-85). Heavy rains during the spring of 1984 were responsible for the annual precipitation being 9 percent above normal for that year. By comparison, the 1985 water year was 22 percent below normal; this deficiency was noticeable particularly during the latter part of the year. Figure 6 illustrates the weekly distribution of total precipitation for the period. Precipitation also was recorded at the North Fork Bens Creek watershed during the 1985 water year. Some records in October and November are missing, but the total for the year is estimated to be about $1,016 \mathrm{~mm}$ or within 3 percent of that measured at South Fork.

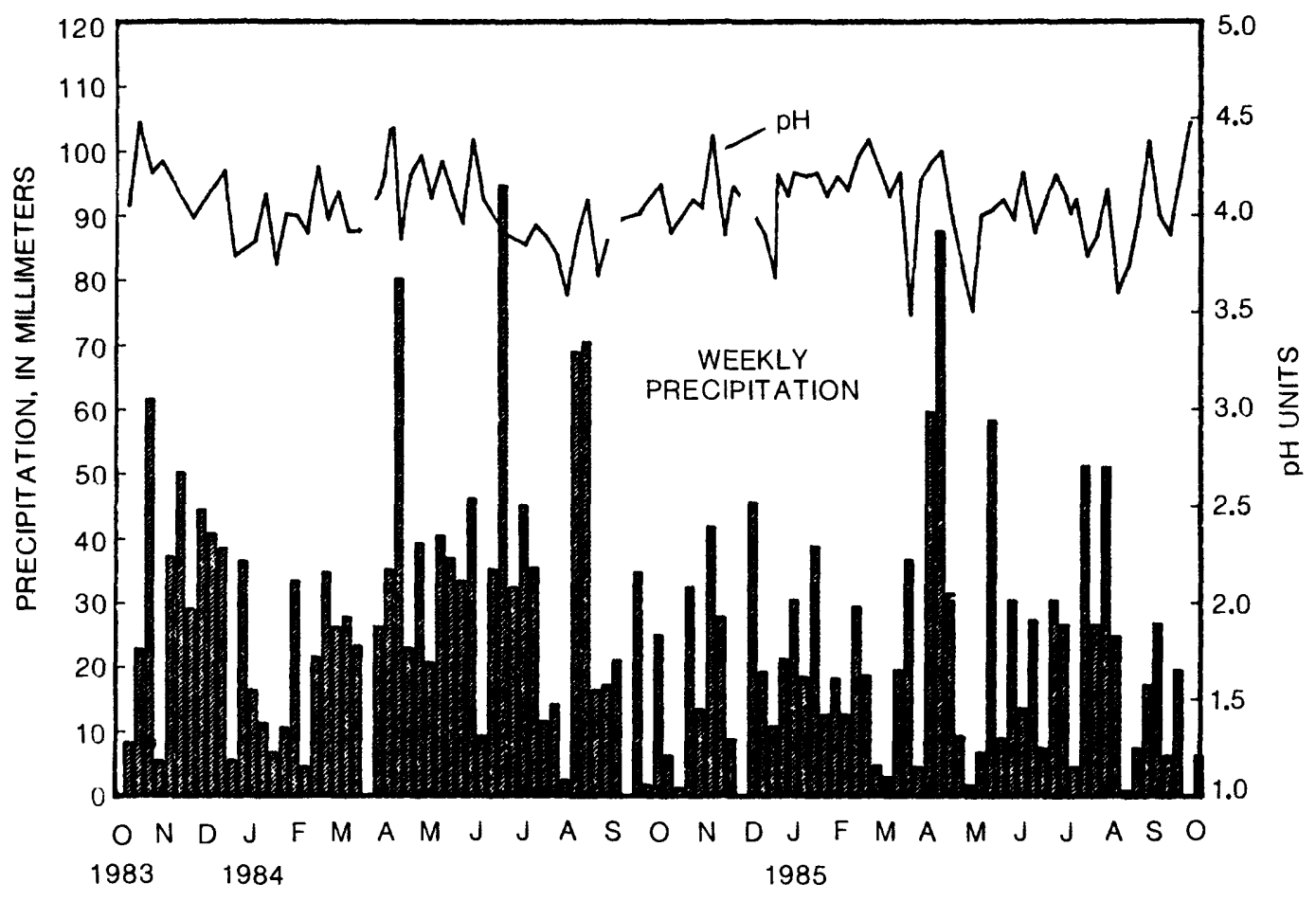

Figure 6.-Weekly precipitation and mean $\mathrm{pH}$ in South Fork Bens Creek watershed, 1984-85 water years. 


\section{Chemistry \\ Assessment of precipitation chemistry is based primarily on weekly and event samples of rain and snow collected at the South Fork Bens Creek site}

from September 1983 through February 1986 (table 7). As illustrated in figure 7 , hydrogen and sulfate are the dominant ions in the composition of precipitation, averaging about 33 and 32 percent, respectively. These percentages are typical of precipitation in the northeastern United States. Nitrate, on the other hand, averaged about 15 percent of the total ionic composition: cations, 10 percent; and chloride, 3 percent.

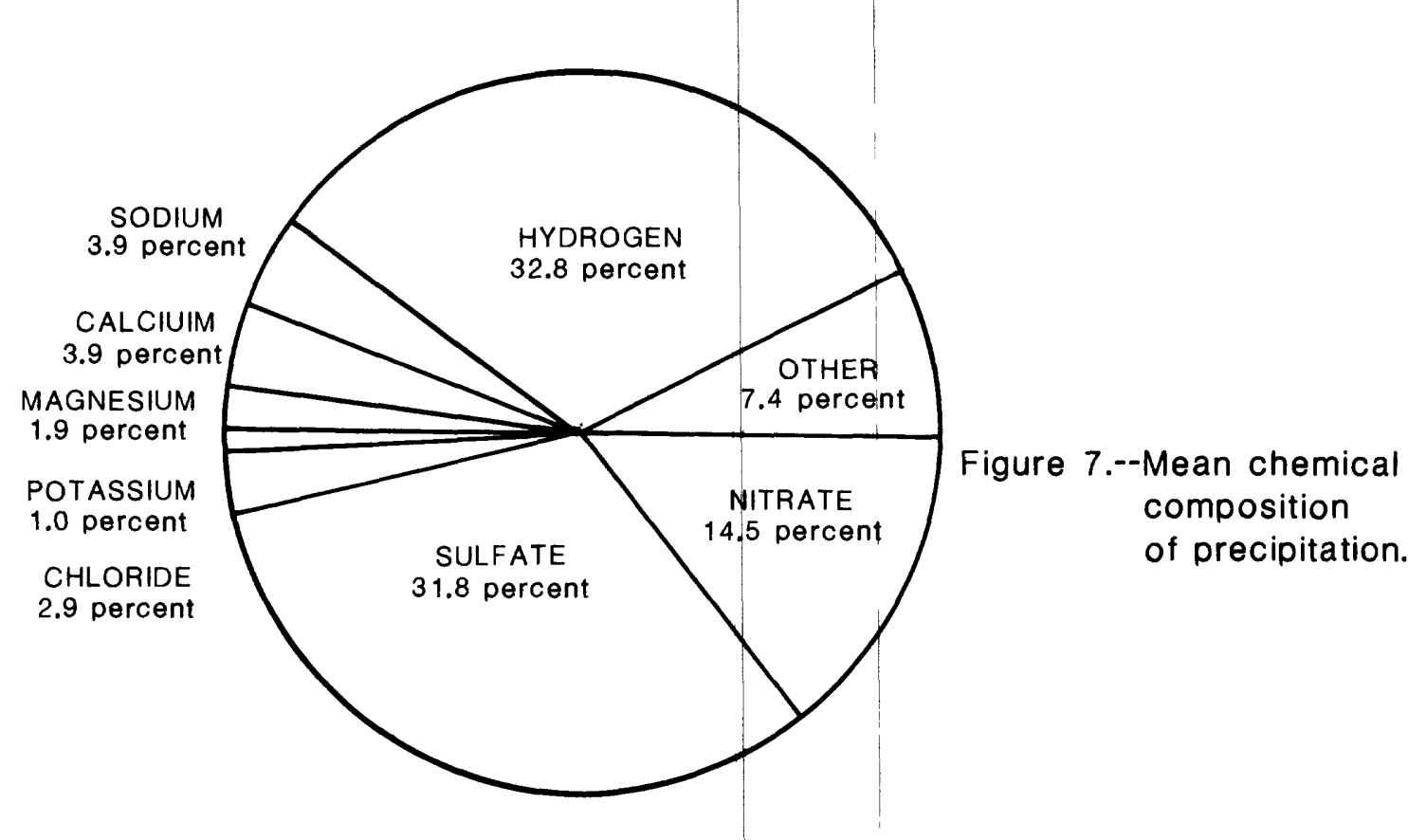

The volume-weighted mean concentrations of the major ions in

precipitation for the 1984-85 water years are presented in table 8 for comparison with concentrations at other atmospheric deposition monitoring sites in the northeast (Bowersox and DePena, 1980; Galloway and Likens, 1981; Shaffer and Galloway, 1982). The volume-weighted means are, in general, comparable to the values reported elsewhere, with some exceptions. Dissolved sodium, for example, was 6 to 19 times greater than that measured at other sites in the northeastern U.S. The average sulfate concentration measured in precipitation at South Fork Bens Creek was $3.6 \mathrm{mg} / \mathrm{L}$ (milligrams per 1iter), but only $2.8 \mathrm{mg} / \mathrm{L}$ at Shenandoah National Park in Virginia (Shaffer, 1982), 1.9 $\mathrm{mg} / \mathrm{L}$ at Biscuit Brook in the Catskill Mpuntains of New York (P.S. Murdoch, U.S. Geological Survey, written commun., 1986), $3.8 \mathrm{mg} / \mathrm{L}$ at Leading Ridge near State College, Pennsylvania, and $2.4 \mathrm{mg} / \mathrm{L}$ at Laurel Hill State Park, Pennsylvania (James Lynch, Pennsylvania State University, written commun., 1985).

Dissolved nitrate, on the other hand, averaged $2.2 \mathrm{mg} / \mathrm{L}$ at South Fork Bens Creek compared with $1.5 \mathrm{mg} / \mathrm{L}$ at Shenandoah Park, Va. and $1.7 \mathrm{mg} / \mathrm{L}$ at Biscuit Brook, N.Y. The reasons for the wide variation in precipitation chemistry for some constituents has not been determined, but probably is related to the proximity of local influences such as the coal-fired generators and steel mills to the west and southwest of Laurel Hill. 
The $\mathrm{pH}$ of precipitation measured at South Fork Bens Creek is among the lowest of any monitored site in Pennsylvania and considerable lower ( 3.59 to 4.48) than many other sites in the northeastern U.S. for which long-term data are available. The volume-weighted average $\mathrm{pH}$ for the period 1984-85 was 4.06. Precipitation was slightly more acidic ( $\mathrm{pH}=4.00$ ) during the growing season than during the dormant season $(\mathrm{pH}=4.10)$. Figure 6 illustrates the weekly precipitation $\mathrm{pH}$ for the period of study at South Fork Bens Creek.

A Pearson correlation coefficient $(r)$ and coefficient of determination $\left(r^{2}\right)$ were calculated for the 1984 data to determine the degree of association between sulfate and $\mathrm{pH}$ and nitrate and $\mathrm{pH}$ in precipitation. The results of the statistical analysis indicate that a strong inverse relation exists between sulfate and $\mathrm{pH}$, and between nitrate and $\mathrm{pH}$ ( $\mathrm{r}$ values of -0.60 and -0.65 , respectively).

Seasonal and annual input loads are summarized in table 9. Although the loading of most major ions was greatest during the November to April dormant season, 1984 sulfate and hydrogen-ion loads were highest during the May to October growing season. The data further suggest that, not only did sulfate and $\mathrm{pH}$ correlate, but also that sulfate in the form of sulfuric acid was primarily responsible for the highly acidic precipitation and that nitric acid also was a contributor, especially during the dormant season. 


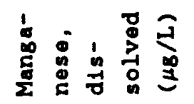

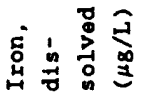

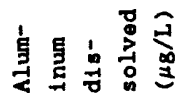

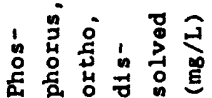

(2)

:

政

ํㅜㄹ

में

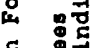

苟

若



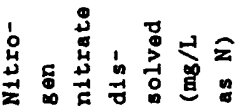

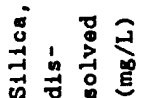

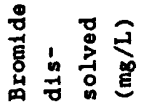

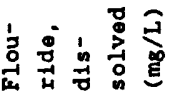

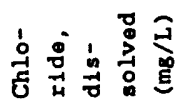

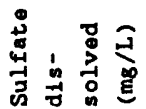

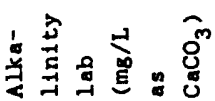

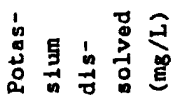

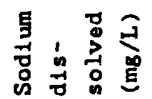

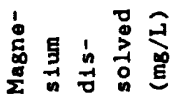

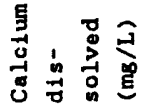

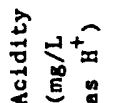

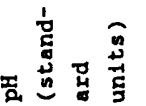

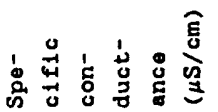

$\stackrel{8}{\mathrm{E}}$

๕̊․․

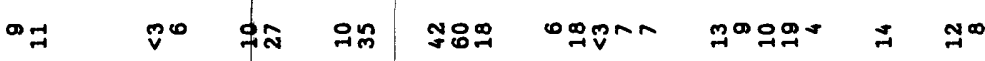

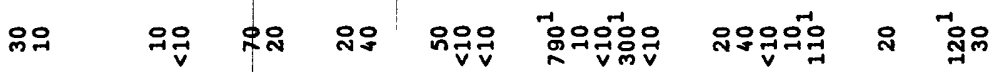

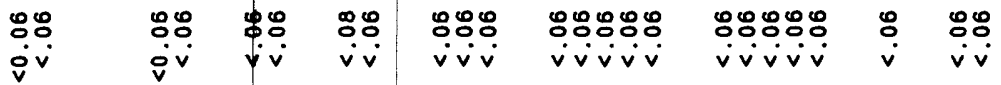

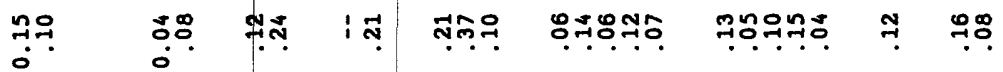

$0000 \quad 0000 \quad 0000000000000000$

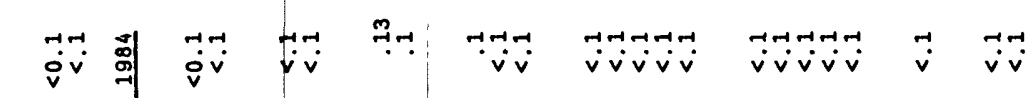

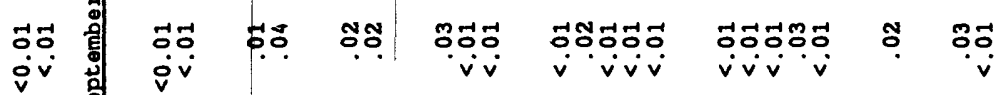

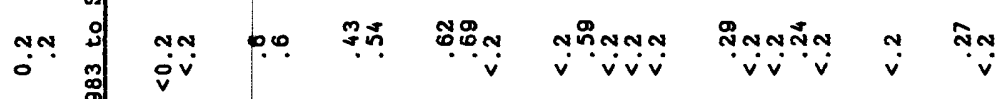

is o:

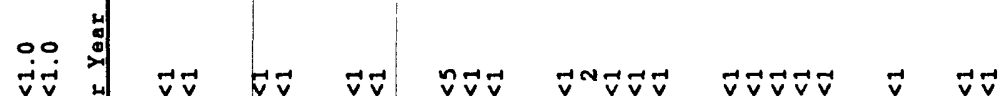

웅 औ

me. 费

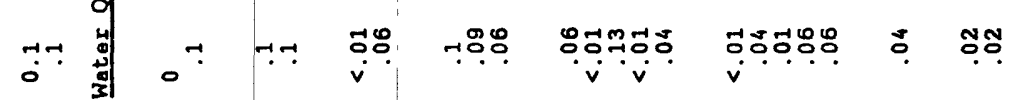

ำ

11

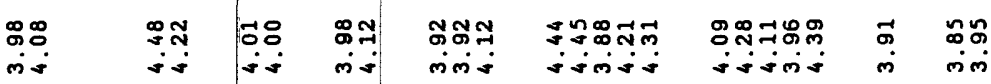

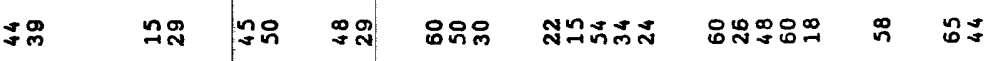

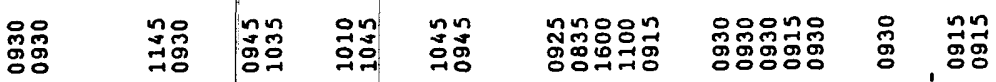

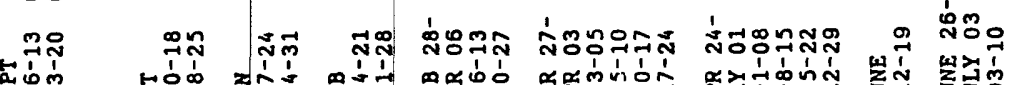

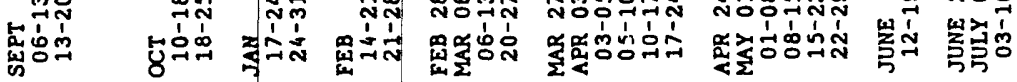




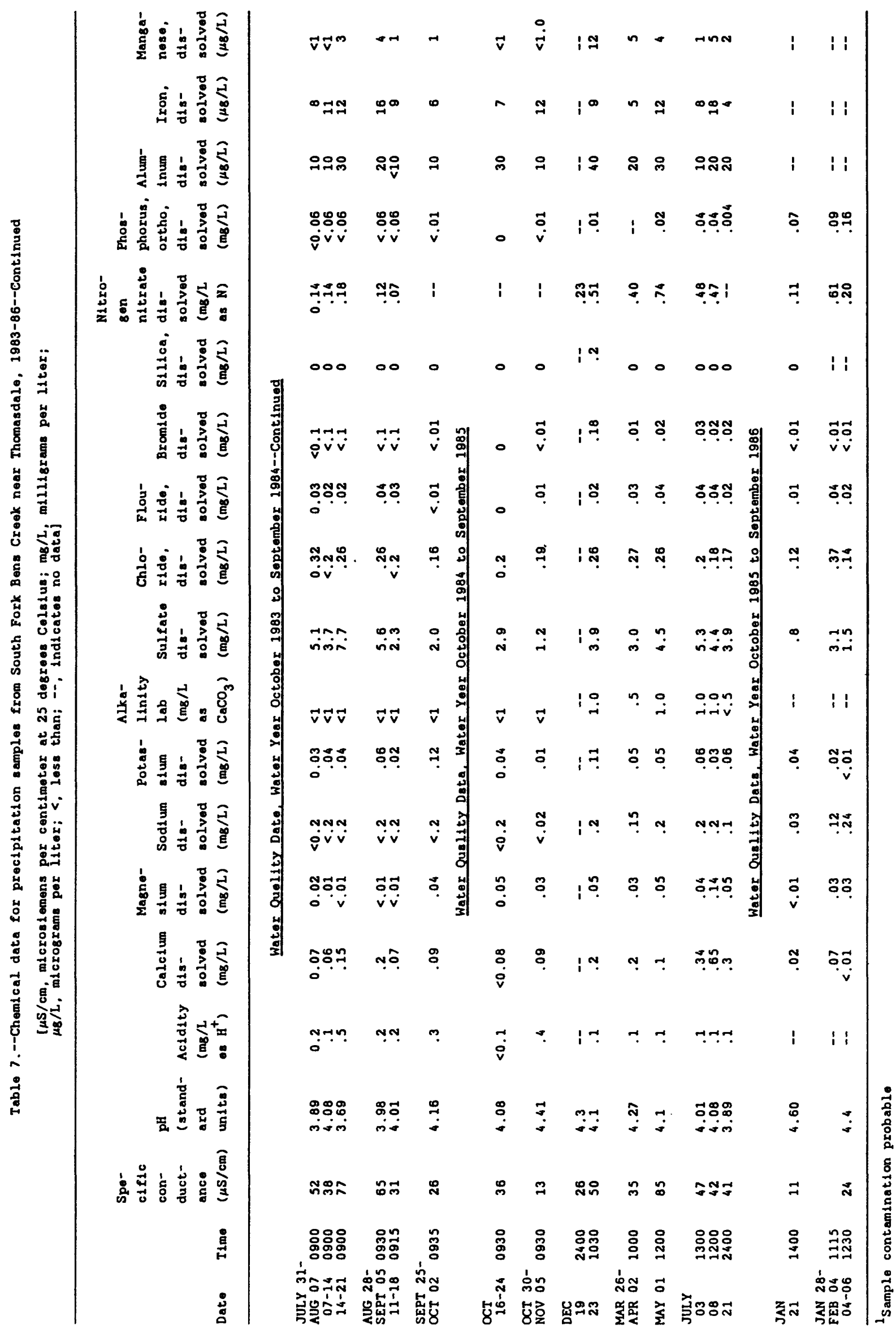


Table 8.--Volume-weighted mean $\mathrm{pH}$ and concentrations of major ions in precipitation at four monitoring stations in the northeastern part of the study area

[mg/L, milligrams per liter; $\mu$ eq/h, microequivalents per liter;

--, no data available]

\begin{tabular}{|c|c|c|c|c|c|c|c|c|c|c|}
\hline & \multirow{2}{*}{$\frac{1984}{m g / L}$} & $\begin{array}{l}\text { South Fork } \\
\text { er year }\end{array}$ & \multicolumn{2}{|c|}{$\begin{array}{l}\text { Bens Creek } \\
1985 \text { water year }\end{array}$} & \multicolumn{2}{|c|}{\begin{tabular}{c|c}
$\begin{array}{c}\text { Shenandoah Park, } \\
1980-81^{1}\end{array}$ & VA \\
\end{tabular}} & \multicolumn{2}{|c|}{$\begin{array}{l}\text { Laurel Bill } \\
\text { State Park, PA } \\
1984^{2} \\
\end{array}$} & \multicolumn{2}{|c|}{$\begin{array}{l}\text { Biscuit Brook, NY } \\
1984^{3} \\
\end{array}$} \\
\hline & & $\mu e q / L$ & $\mathrm{mg} / \mathrm{L}$ & $\mu e q / L$ & $\mathrm{mg} / \mathrm{L}$ & $\mu \theta \mathrm{q} / \mathrm{L}$ & $\mathrm{mg} / \mathrm{L}$ & $\mu e q / L$ & $\mathrm{mg} / \mathrm{L}$ & $\mu e q / L$ \\
\hline Calcium & 0.23 & 11.3 & 0.19 & 9.5 & 0.25 & 12.6 & 0.21 & 10.5 & -- & -- \\
\hline Magnesium & .04 & 3.3 & .05 & 4.1 & .054 & 4.4 & .07 & 5.8 & -- & -- \\
\hline Sodium & .26 & 11.3 & .25 & 10.9 & .014 & 6 & .04 & 1.7 & -- & -- \\
\hline Potassium & .06 & 1.5 & .08 & 2.1 & .081 & 2.1 & .06 & 1.5 & -- & -- \\
\hline $\mathrm{pH}$ & 4.06 & 87.1 & 4.05 & 88.5 & 4.27 & 53.7 & 4.14 & 72.4 & 4.25 & 55 \\
\hline Nitrate & 2.43 & 39.3 & 1.95 & 31.4 & 1.50 & 24.3 & 2.17 & 35 & 1.48 & 23.9 \\
\hline Sulfate & 4.13 & 86 & 3.3 & 68.7 & 2.79 & 58.1 & 2.41 & 50.2 & 1.93 & 40.1 \\
\hline Chloride & .31 & 8.75 & .22 & 6.17 & .35 & 9.8 & .30 & 8.5 & .22 & 6.3 \\
\hline
\end{tabular}

Shaffer and Galloway, 1982.

$2 \mathrm{~J}$. Lynch, Pennsylvania State University, written commun., 1985.

${ }^{3}$ P. Murdock, U.S. Geological Survey, written commun., 1986. 
Table 9.--Seasonal and annual input loads of major ions in precipitation at South Fork and North Fork Bens Creek watersheds

[Units are kilograms per hectare except for amount of precipitation, which is given in millimeters]

\begin{tabular}{|c|c|c|c|}
\hline & Season $^{1}$ & $\begin{array}{l}\text { Loads at } \\
\text { South Fork, } \\
1984\end{array}$ & $\begin{array}{l}\text { Loads at } \\
\text { North Fork, } \\
1985\end{array}$ \\
\hline $\begin{array}{l}\text { Amount of } \\
\text { precipitation }\end{array}$ & $\begin{array}{l}\text { growing } \\
\text { dormant } \\
\text { annual }\end{array}$ & $\begin{array}{r}751 \\
731 \\
1,482\end{array}$ & $\begin{array}{r}444 \\
572 \\
1,016\end{array}$ \\
\hline Calcium & $\begin{array}{l}\text { growing } \\
\text { dormant } \\
\text { annual }\end{array}$ & $\begin{array}{l}1.18 \\
2.72 \\
3.89\end{array}$ & $\begin{array}{r}.74 \\
1.98 \\
2.72\end{array}$ \\
\hline Magnesium & $\begin{array}{l}\text { growing } \\
\text { dormant } \\
\text { annual }\end{array}$ & $\begin{array}{l}.25 \\
.39 \\
.64\end{array}$ & $\begin{array}{l}.18 \\
.29 \\
.47\end{array}$ \\
\hline Sodium & $\begin{array}{l}\text { growing } \\
\text { dormant } \\
\text { annual }\end{array}$ & $\begin{array}{l}1.39 \\
2.28 \\
3.67\end{array}$ & $\begin{array}{r}.92 \\
1.98 \\
2.90\end{array}$ \\
\hline Potassium & $\begin{array}{l}\text { growing } \\
\text { dormant } \\
\text { annual }\end{array}$ & $\begin{array}{r}.39 \\
.82 \\
1.21\end{array}$ & $\begin{array}{l}.23 \\
.47 \\
.70\end{array}$ \\
\hline Nitrate & $\begin{array}{l}\text { growing } \\
\text { dormant } \\
\text { annual }\end{array}$ & $\begin{array}{l}3.48 \\
4.85 \\
8.33\end{array}$ & $\begin{array}{l}2.07 \\
4.10 \\
6.17\end{array}$ \\
\hline Sulfate & $\begin{array}{l}\text { growing } \\
\text { dormant } \\
\text { annual }\end{array}$ & $\begin{array}{l}34.11 \\
25.32 \\
59.43\end{array}$ & $\begin{array}{l}20 \\
20.30 \\
40.30\end{array}$ \\
\hline Hydrogen & $\begin{array}{l}\text { growing } \\
\text { dormant } \\
\text { annual }\end{array}$ & $\begin{array}{r}.727 \\
.634 \\
1.361\end{array}$ & $\begin{array}{l}.393 \\
.471 \\
.864\end{array}$ \\
\hline Chloride & $\begin{array}{l}\text { growing } \\
\text { dormant } \\
\text { annual }\end{array}$ & $\begin{array}{l}1.79 \\
2.54 \\
4.33\end{array}$ & $\begin{array}{l}1.20 \\
2.13 \\
3.33\end{array}$ \\
\hline
\end{tabular}




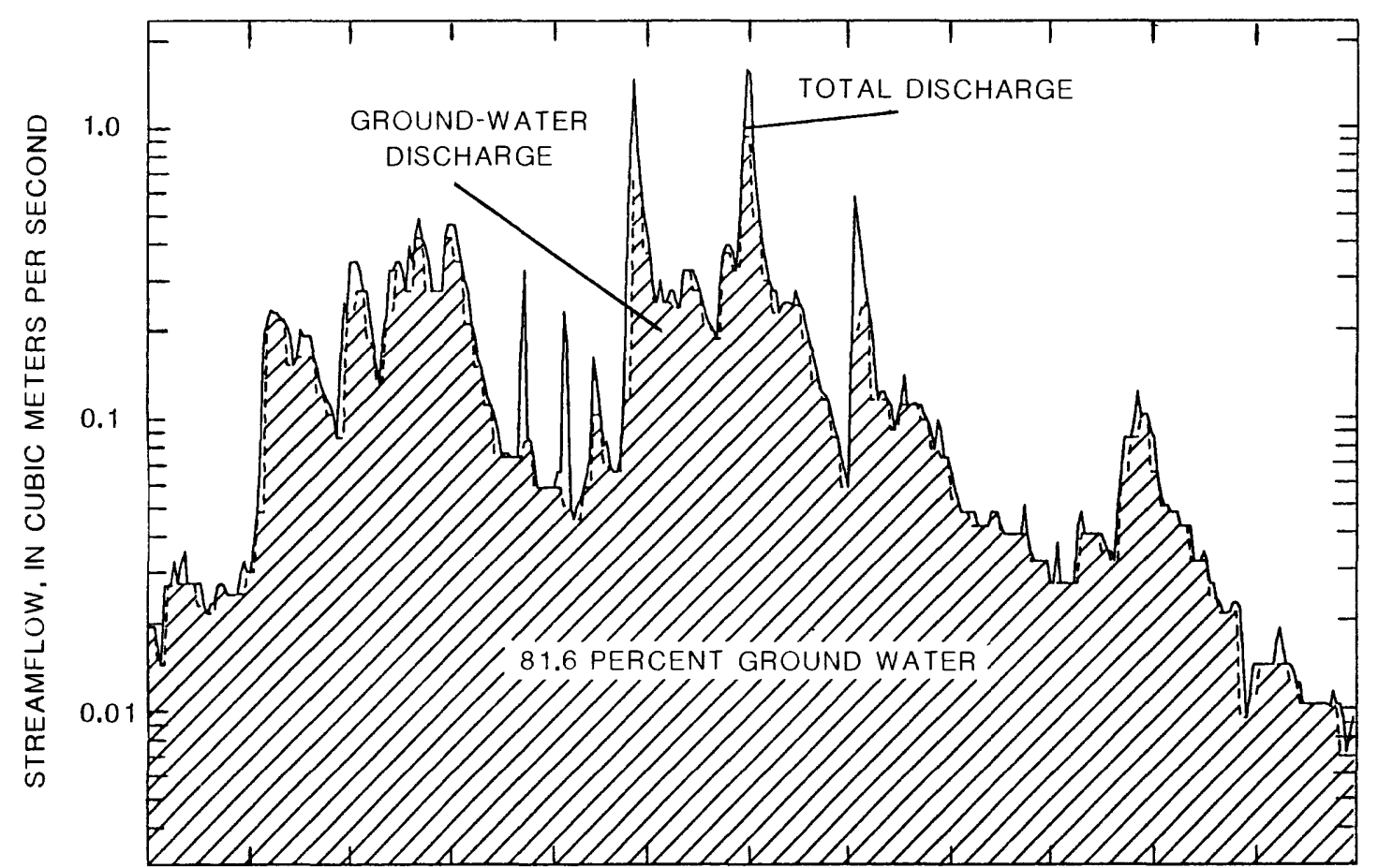

OCT. NOV. DEC. JAN. FEB. MAR. APR. MAY JUNE JULY AUG. SEPT. OCT. 1984 1985

Figure 9.--Separation of streamflow components, South Fork Bens Creek, 1985 water year.

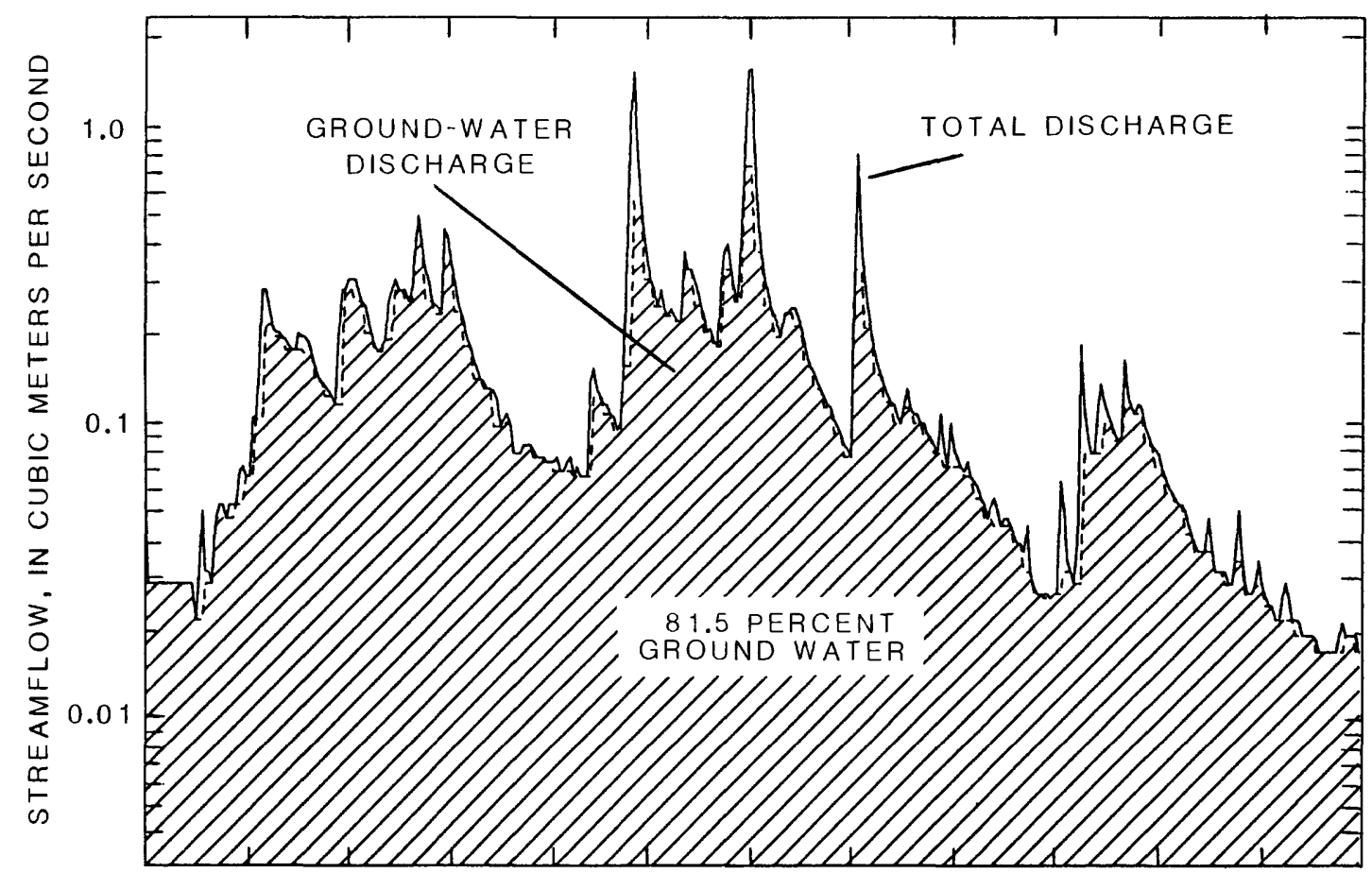

OCT. NOV. DEC. JAN. FEB. MAR. APR. MAY JUNE JULY AUG. SEPT. OCT. 1984 1985

Figure 10.--Separation of streamflow components, North Fork Bens Creek, 1985 water year. 


\section{Chemistry}

Monthly streamflow chemistry of the South Fork Bens Creek, North Fork Bens Creek, Garys Run, Cole Run, and North Branch Quemahoning Creek was measured over a range of flow conditions typical of the high and low base-flow periods. Temporal variability in constituent concentration of major ions is illustrated in figure 11. Concentrations of $\mathrm{pH}$, acid-neutralizing capacity, (ANC), and chloride were greater during low base-flow periods when streamflow was composed predominantly of water from the saturated zone. Dissolved aluminum concentrations were greater during winter and during spring snowmelt than at other times of the year. Sulfate concentrations have no obvious seasonal or flow-related trends. Nitrate concentrations, on the other hand, increase during the dormant season in both the North Fork Bens Creek and Garys Run.

The ANC of streams on Laurel Hill, as described by DeWalle and others (1987), is a function of carbonate-rock burial depth, extent of carbonate-rock recharge areas, and length of stream channel flowing in reaches underlain by carbonate rock. The illustrations in figure 12 depict the dependence of ANC on streamflow and the variability of ANC for three streams in the study area of Laurel Hill. At low flow, when discharge is primarily from ground water, ANC values are about 4 to 5 times greater than during periods of stormflow runoff. ANC at South Fork Bens Creek averaged about $90 \mu \mathrm{eq} / \mathrm{L}$ (microequivalents per liter), North Fork Bens Creek averaged about $19 \mu \mathrm{eq} / \mathrm{L}$, and Garys Run averaged about $7 \mu \mathrm{eq} / \mathrm{L}$. The other two satellite streams had no available source of buffering and, thus, no neutralizing capacity.

Analysis of the chemistry of the five study streams indicates there is considerable variability in the composition and degree of acidification of streams in the Laurel Hills. Cole Run and North Branch Quemahoning Creek are strongly acidic and concentrations of most constituents change little over time, whereas Garys Run, North Fork Bens Creek, and South Fork Bens Creek are less acidified. Because all the watersheds receive about the same atmospheric inputs, bedrock geology determines the rate of the acidification process. The importance of bedrock geology to the acidification process is described in detail by DeWalle and others (1987), Sharpe and others (1987), and Katz and others (1985).

The volume-weighted mean concentration of the major constituents in the South Fork, North Fork, and in precipitation (table 10) indicates there may be considerable exchange of minerals and gases between the atmospheric inputs and the watershed. Hydrogen, which was the major cation in precipitation, becomes insignificant with respect to the ionic balance of the stream chemistry. Because of the alkaline earths in the watershed soils, calcium replaces hydrogen as the dominant cation, accounting for about 40 percent of the total cationic concentration. Dissolved aluminum, which is discussed more fully in a later section, is a significant cation during periods of runoff and increased acidity. 
Sulfate was the dominant anion in the streams; it comprised 63 to 68 percent of the total anions on the basis of equivalents compared to about 38 percent of the total loss in precipitation, whereas nitrate accounted for only 3 or 4 percent of the total anions. Chloride accounted for 9 and 27 percent of the anions in the South Fork Bens Creek and North Fork Bens Creek, respectively. The high percentage of chloride in the North Fork may be attributed to possible contamination of the ground water by an abandoned gas well or road salt applied at the crest of the basin or both, but this was not confirmed.

The volume-weighted $\mathrm{pH}$ for the 1984 water year at South Fork Bens Creek ranged from 5.60 to 7.00 and averaged 6.29 , and the North Fork ranged from 5.30 to 6.51 and averaged 5.68 in the 1984 water year and 5.88 in the 1985 water year. As illustrated in figures 13 and 14 , the lowest $\mathrm{pH}$ values were associated with periods of peak runoff from precipitation and snowmelt. 

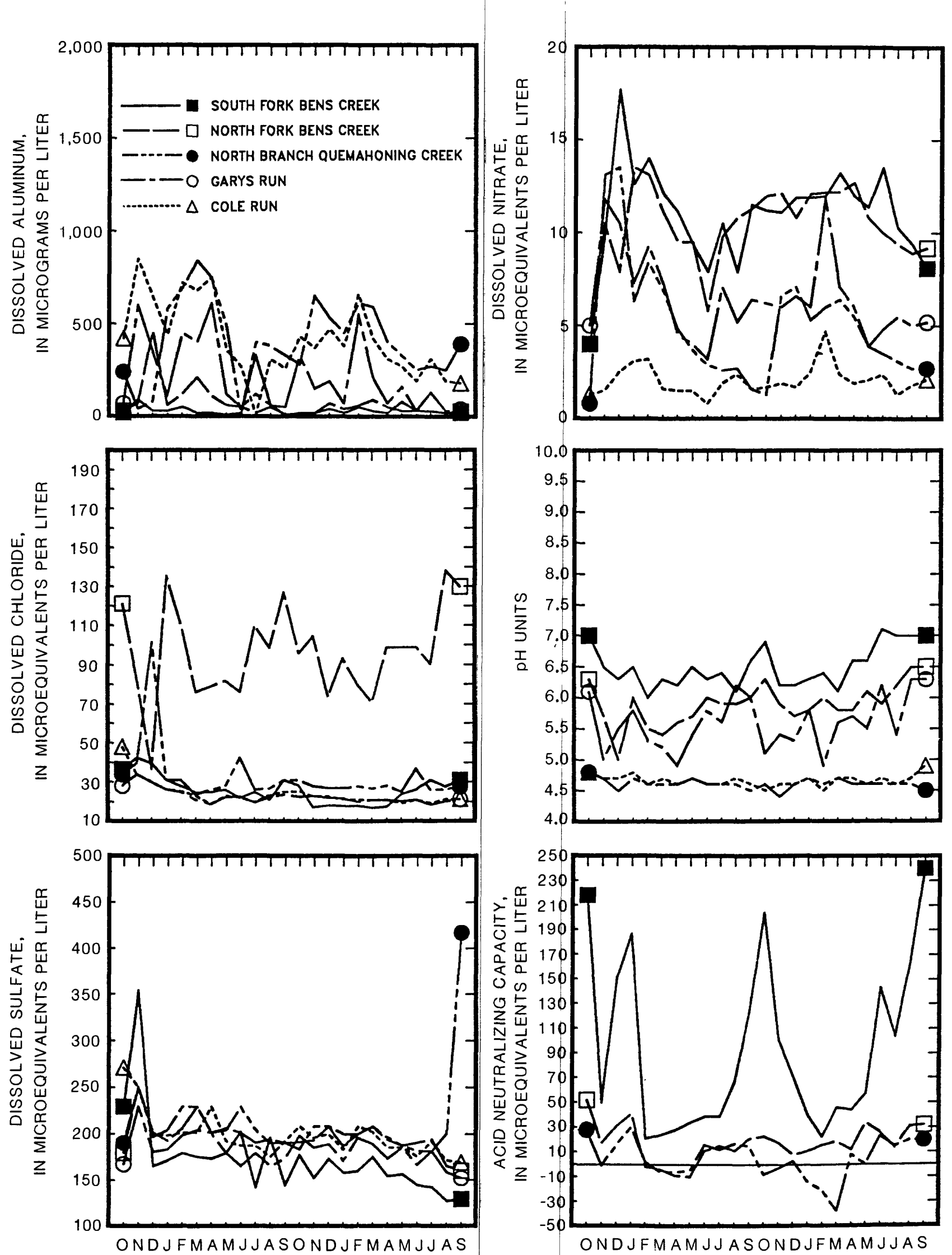

Figure 11.--Monthly instantaneous constituent concentrations during base flow, 1984-85 water years. 

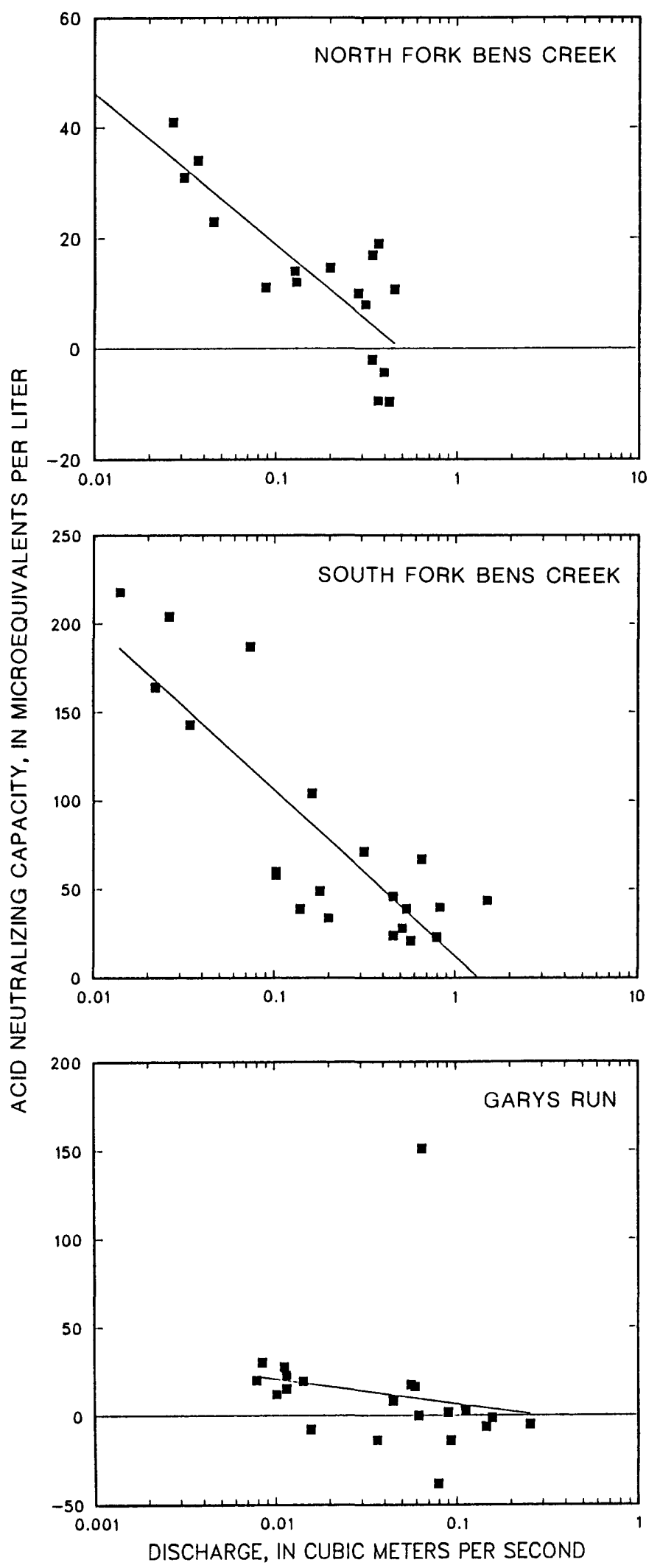

Figure 12.--Relation between streamflow and acid-neutralizing capacity for three streams on Laurel Hill, 1984-85 water years. 
Table 10.--Volume-weighted mean concentrations of major ions and silica in precipitation and stream water,

1984-84 water years

[mg/L, milligrams per liter; $\mu \mathrm{eq} / \mathrm{L}$, microequivalent per 1iter; wy, water year; -. no data available]

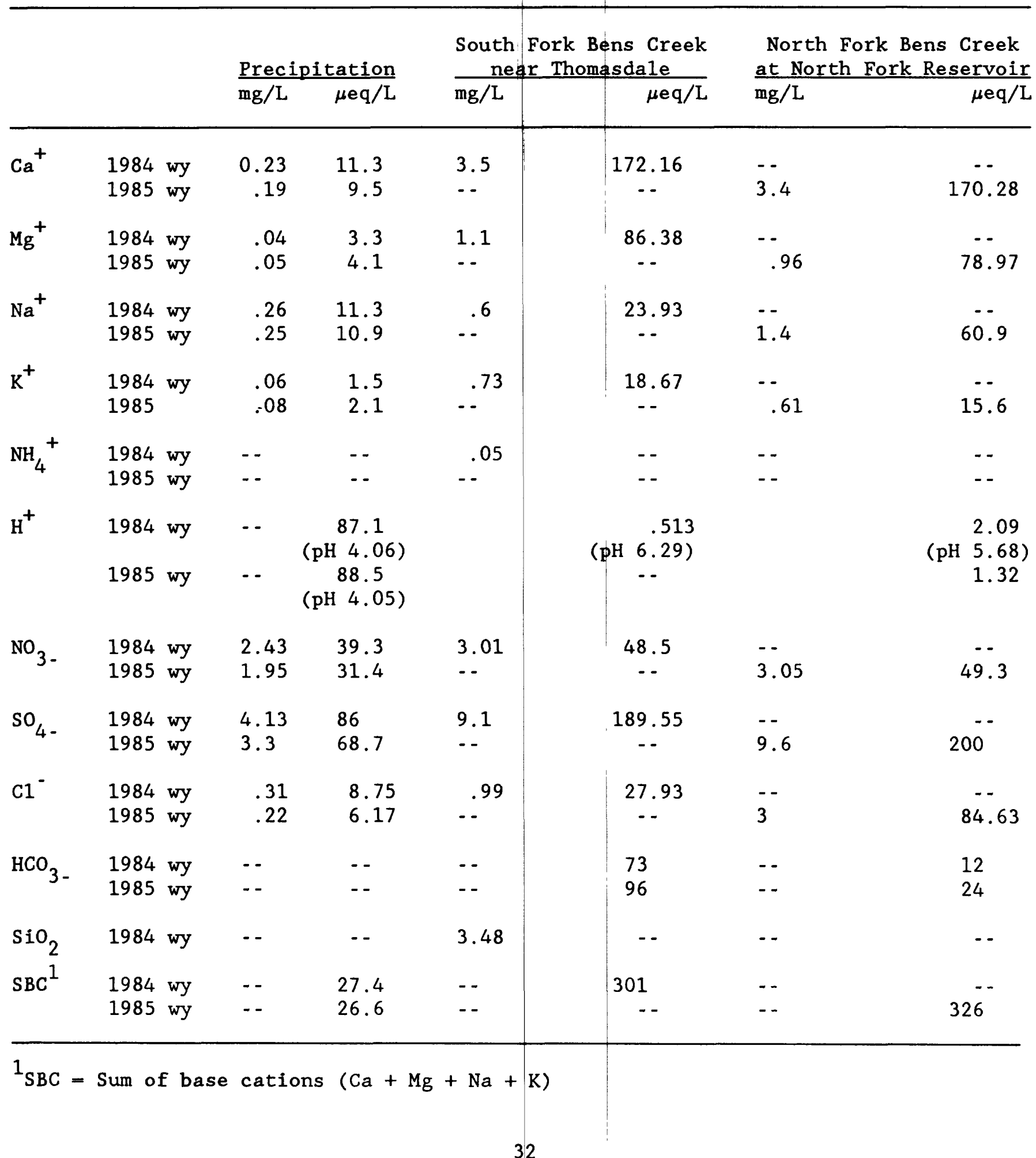




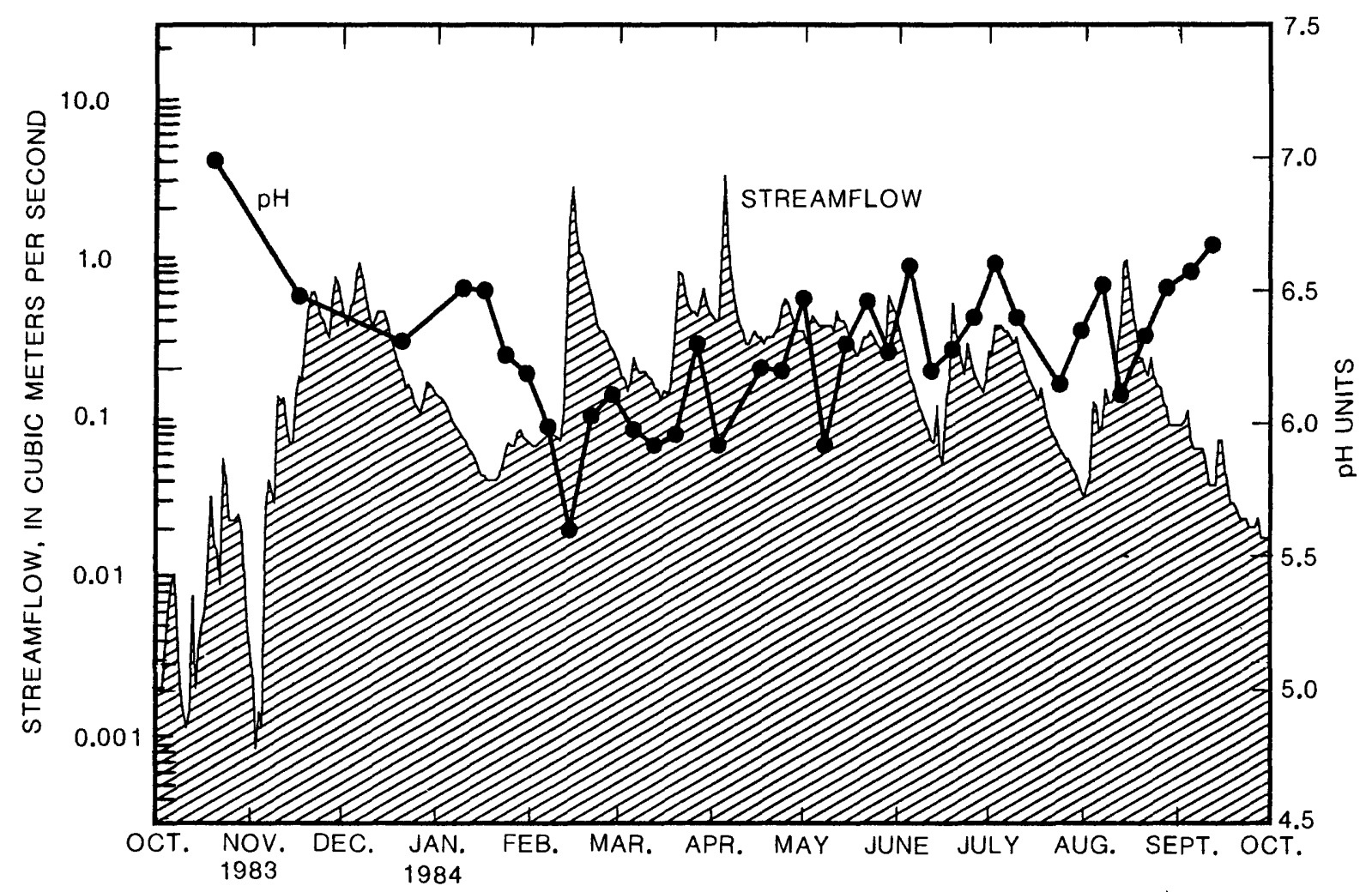

Figure 13.--Daily mean streamflow and weekly instantaneous $\mathrm{pH}$ at South Fork Bens Creek near Thomasdale, 1984 water year.

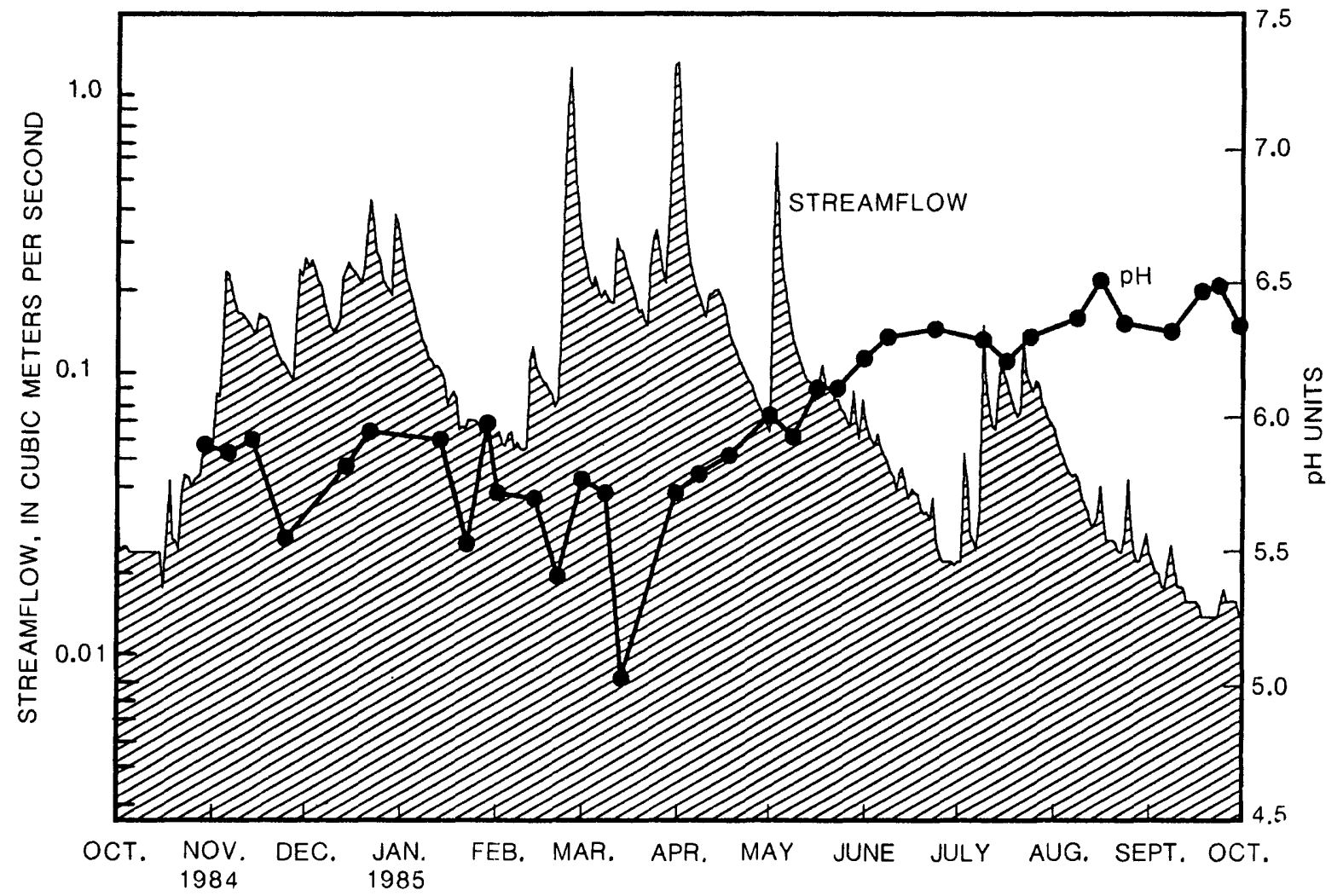

Figure 14.--Daily mean streamflow and weekly instantaneous $\mathrm{pH}$ at North Fork Bens Creek at North Fork Reservoir 1985 water year. 


\section{Water Budgets}

Table 11 summarizes the monthly water-budget estimates for the study period. Runoff at South Fork Bens Creek was about 67 percent of precipitation during 1984 and 1985 and about 59 percent at North Fork in 1985. Evapotranspiration plus change in storage for the study area averaged about $420 \mathrm{~mm}$ per year, or 36 percent of precipitation (Kohler and others, 1959).

\section{Chemica1 Budgets}

Results of chemical loading, outflow, and net flux, summarized in figures 15 and 16 and tables 12 and 13, indicate a net loss of base cations, sulfate, and chloride, and a net accumulation of nitrate in both basins. Some of the apparent net losses may be because of the unmeasured dry deposition component in the precipitation load calculation.

Sulfate output from both the South Fork and North Fork basins greatly exceeded wet-deposition loads. Wet deposition loads can account only for about 77 percent of the output in the South Fork basin in 1984 and 1985, respectively. The net outputs not accounted for are from natural sources within the watershed and from dry deposition of unknown quantities.

The Running Net Flux (RNF) for sulfate is depicted in figures 15 and 16 , which illustrate seasonal change in slope for net flux in 1984 and 1985. Sulfate was nearly steady state $(R N F=0)$ during the period of snow cover; large releases of sulfate occurred during snowmelt periods and net accumulations occurred during the growing season. This pattern is nearly identical to the one observed in the Catskil1 Mountains of New York (Murdoch, P.S., U.S. Geological Survey, written commun., 1986).

The net flux for nitrate shows that about 46 percent was retained in the South Fork and about 50 percent was retained in the North Fork ecosystems. Some evidence of a seasonal pattern in nitrate flux can be observed in the RNF plots for South Fork Bens Creek and North Fork Bens Creek (figs. 15 and 16). Negative slopes of the $\mathrm{NO}_{3} \mathrm{RNF}$ in February and March indicate release of $\mathrm{NO}_{3}$ from the melting snow pack or from leaf litter. Positive slopes in late spring and summer indicate periods of rapid assimilation when biological productivity is high.

Chloride, as pointed out by Galloway and others (1983), commonly is used as an atmospheric tracer in watershed studies because of its naturally low concentration in rock and soil and its low reactivity. The negative accumulation running net flux and retention indices indicate a net loss of chloride from South Fork and North Fork watersheds. The high chloride yields from North Fork watershed, as pointed out earlier, may derive from an abandoned gas well or from road-deicing salt. 
The net losses of cations and sulfate from both watersheds are typical of those observed elsewhere in the northeastern U.S. (Murdoch, P.S., U.S. Geological Survey, written commun., 1986; Galloway and others, 1983). The periodic large negative flux of constituents illustrated in figures 14 and 15 is associated with episodic runoff from snowmelt and storms. Calcium and magnesium, principally from the chemical disassociation and replacement of minerals in the soils account for 99 percent of the total base-cation flux in the South Fork and 74 percent in the North Fork basin. The net-flux data presented in tables 11 and 12 indicate that nearly all the hydrogen ions available from precipitation are retained by the watershed.
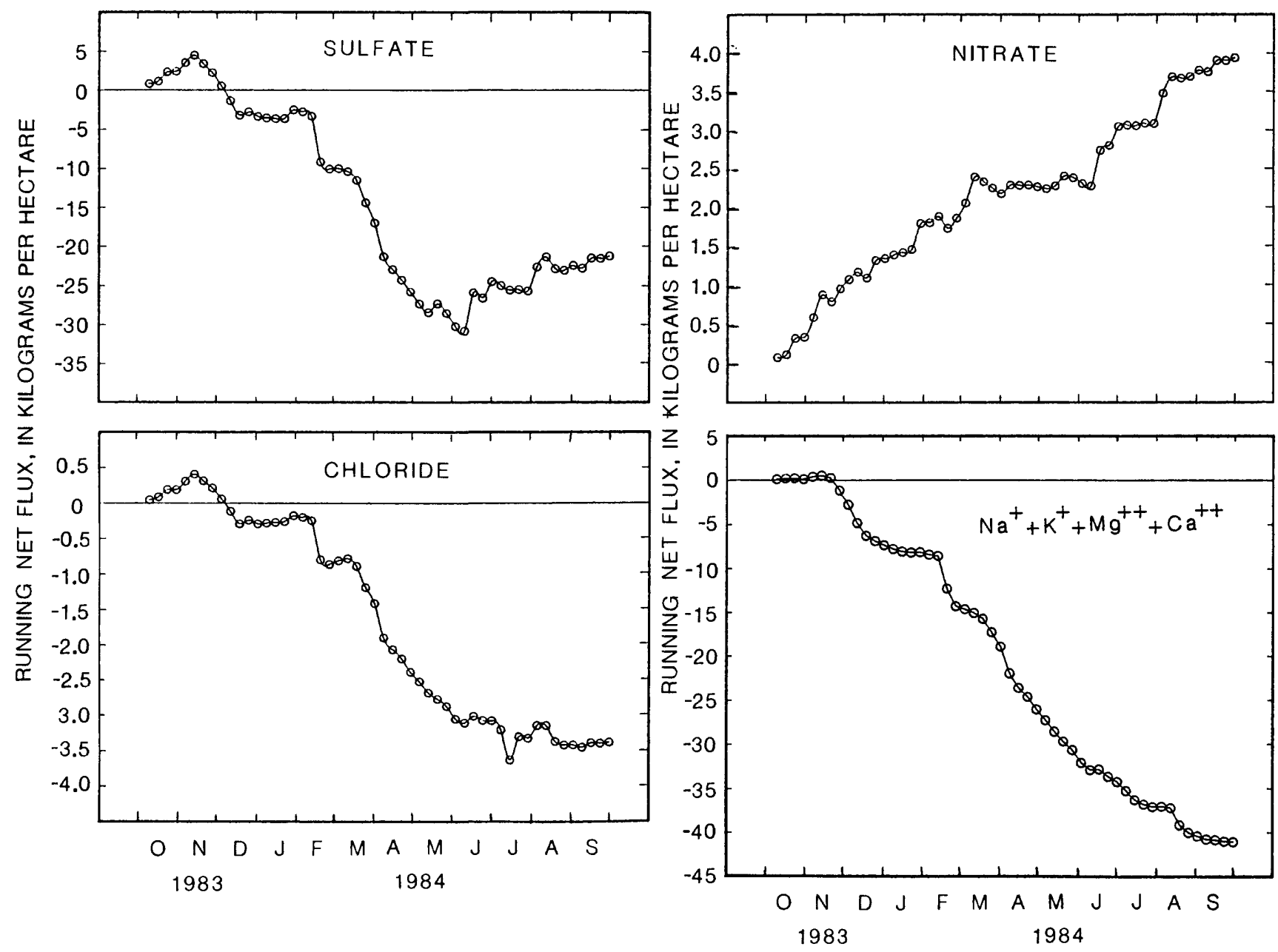

Figure 15.--Selected chemical-constituent net flux for 1984 water year, South Fork Bens Creek near Thomasdale. 

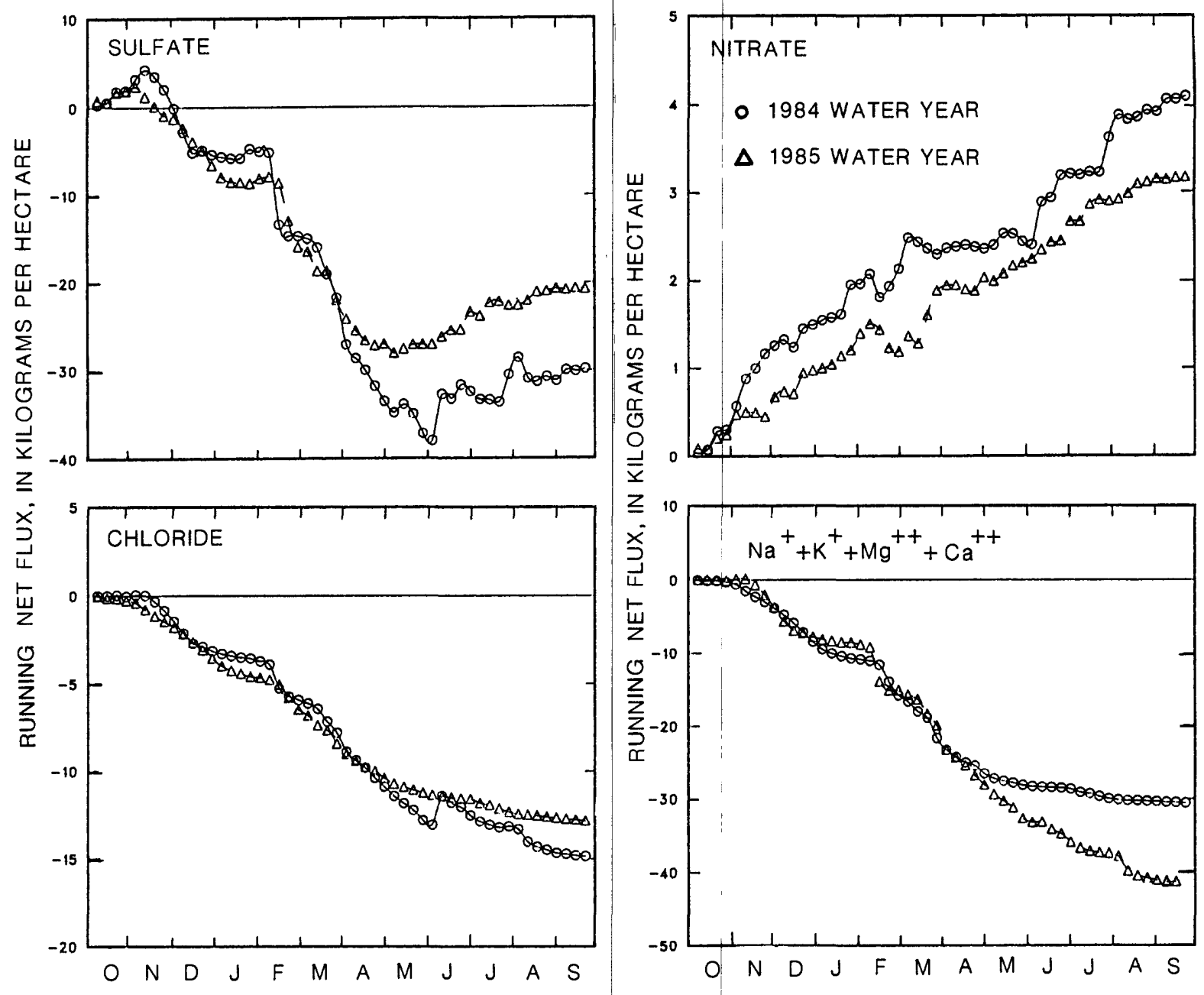

Figure 16.--Selected chemical-constituent net flux for 1984-85 water years, North Fork Bens Creek at North Fork Reservoir. 
Table 11.--Monthly water-budget estimates for the 1984-85 water years at the Bens Creek sites

[mm, millimeter; $\Delta$, change]

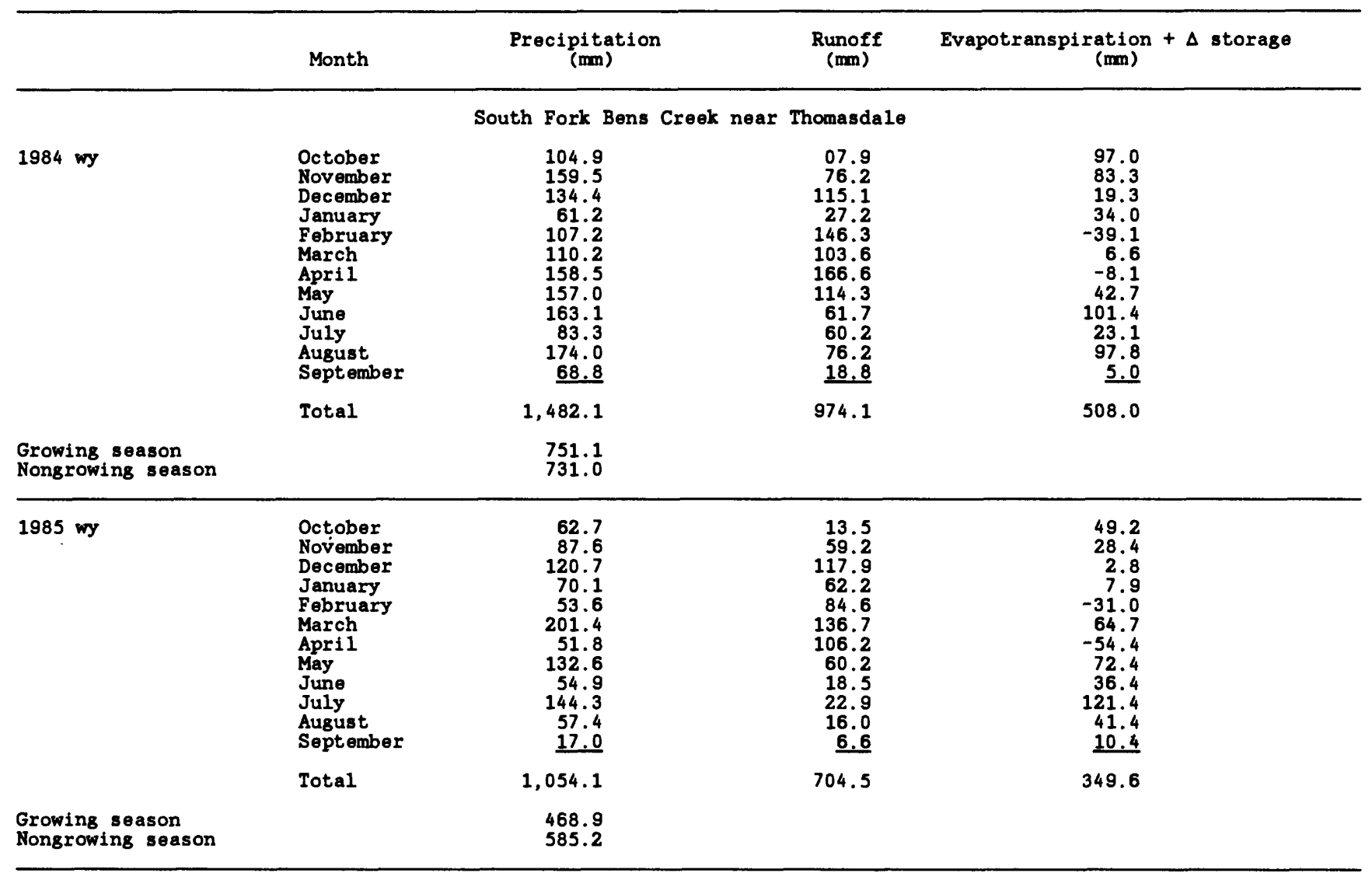

North Fork Bens Creek at North Fork Reservoir

\begin{tabular}{|c|c|c|c|c|}
\hline \multirow[t]{2}{*}{$1985 \mathrm{wy}$} & $\begin{array}{l}\text { October } \\
\text { November } \\
\text { December } \\
\text { January } \\
\text { February } \\
\text { March } \\
\text { April } \\
\text { May } \\
\text { June } \\
\text { July } \\
\text { August } \\
\text { September }\end{array}$ & $\begin{array}{r}62.7 \\
87.6 \\
120.7 \\
73.2 \\
54.4 \\
180.8 \\
54.9 \\
143.3 \\
41.9 \\
131.8 \\
53.1 \\
11.4 \\
\end{array}$ & $\begin{array}{r}11.9 \\
56.6 \\
95.3 \\
43.7 \\
77.0 \\
113.0 \\
85.6 \\
53.3 \\
14.2 \\
28.2 \\
13.0 \\
05.8 \\
\end{array}$ & $\begin{array}{r}50.8 \\
31.0 \\
25.4 \\
29.5 \\
-22.6 \\
67.8 \\
-30.7 \\
90.0 \\
27.7 \\
103.6 \\
40.1 \\
05.6 \\
\end{array}$ \\
\hline & Total & $1,015.8$ & 597.6 & 418.2 \\
\hline $\begin{array}{l}\text { Growing season } \\
\text { Nongrowing season }\end{array}$ & & $\begin{array}{l}444.2 \\
571.6\end{array}$ & & \\
\hline
\end{tabular}


Table 12.--Summary of annual input and output flux for precipitation and streamflow at South Fork Bens Creek in 1984 water year

[Units are kilograms per hectare except for water, which is in millimeters. Positive net flux values represent accumulation in the watershed.]

\begin{tabular}{|c|c|c|c|c|}
\hline & $\begin{array}{c}\text { PPT } \\
\text { input }\end{array}$ & output & Net flux & $\begin{array}{l}\text { Retention } \\
\text { index } \\
(\mathrm{RI})^{1}\end{array}$ \\
\hline & & ? & & \\
\hline $\mathrm{H}_{2}$ & 1,482 & 974 & + & \\
\hline Calcium & 3.89 & 30.57 & -26.77 & -6.88 \\
\hline Magnesium & .64 & 8.81 & -8.17 & -12.77 \\
\hline Sodium & 3.67 & 4.49 & -0.82 & -.22 \\
\hline Potassium & 1.21 & 6.11 & -4.90 & -4.05 \\
\hline Nitrate & 8.33 & 5.61 & 3.85 & .46 \\
\hline Sulfate & 59.43 & 76.81 & -22.5 & -.38 \\
\hline Chloride & 4.33 & 8.13 & -3.50 & -.81 \\
\hline Hydrogen & 1.361 & .013 & 1.348 & .99 \\
\hline $\mathrm{SBC}^{2}$ & 9.41 & 49.99 & -40.58 & -4.31 \\
\hline $1 \mathrm{RI}=\frac{\operatorname{Net} \text { Flux }}{\sum_{i=1}^{n} \text { (inputs) }_{i}}$ & & & & \\
\hline
\end{tabular}


Table 13.--Summary of annual input and output flux for precipitation and streamflow at North Fork Bens Creok in $1984-85$ water years ${ }^{1}$

CUnits are kilograms per hectare except for water, which is in millimeters. Positive net-flux values represent

accumulation in the watershed, negative net-flux values

represent loss in the watershed; --, no data available]

\begin{tabular}{|c|c|c|c|c|c|c|c|c|}
\hline & \multicolumn{2}{|c|}{$\begin{array}{c}\text { PPT } \\
\text { input }\end{array}$} & \multicolumn{2}{|c|}{ Output } & \multicolumn{2}{|c|}{ Net flux } & \multicolumn{2}{|c|}{$\begin{array}{l}\text { Retention } \\
\text { index }(R I)^{2}\end{array}$} \\
\hline & 1984 & 1985 & 1984 & 1985 & 1984 & 1985 & 1984 & 1985 \\
\hline $\mathrm{H}_{2} \mathrm{O}$ & $1,482.1$ & $1,015.7$ & 974.1 & 598 & -- & -- & -- & -- \\
\hline Calcium & 3.89 & 2.72 & -- & 21.24 & -- & -18.52 & -- & -6.8 \\
\hline Magnesium & .64 & .47 & -- & 5.77 & -- & -5.30 & -- & -11.3 \\
\hline Sodium & 3.67 & 2.90 & -- & 8.19 & -- & -5.29 & -- & -1.8 \\
\hline Potassium & 1.21 & .70 & -- & 3.84 & -- & -3.14 & -- & -4.5 \\
\hline Nitrate & 8.33 & 6.17 & 4.34 & 3.02 & 4.09 & 3.13 & .5 & .5 \\
\hline Sulfate & 59.43 & 40.30 & 88.84 & 62.26 & -29.84 & -20.74 & -.5 & -.5 \\
\hline Chloride & 4.33 & 3.33 & 20.89 & 16.21 & -14.86 & -12.87 & -3.8 & -3.9 \\
\hline Hydrogen & 1.36 & .86 & .13 & .16 & 1.35 & .85 & .99 & .98 \\
\hline$S B C^{3}$ & 9.41 & 6.79 & 50.62 & 39.04 & -41.36 & -30.57 & -- & -4.5 \\
\hline
\end{tabular}

$1_{1984}$ water year values calculated by correlation-analysis procedures.

$2_{R I}=\frac{\text { Net } f l u x}{\sum_{i=1}^{n} \text { (inputs) }}$

${ }^{3} \mathrm{SBC}=$ Sum of base cations $\left(\mathrm{Ca}+\mathrm{Mg}_{8}+\mathrm{Na}+\mathrm{K}\right)$.

\section{EFFECTS OF ACIDIC PRECIPITATION ON THE WATER QUALITY OF STREAMS IN THE LAUREL HILL AREA}

Part of this study was devoted to observing the response of chemistry to stormflow. To do this, both primary sites, South Fork Bens Creek and North Fork Bens Creek, were instrumented for sampling water quality during selected precipitation events. South Fork Bens Creek was stormflow sampled from September 1983 through October 1984; North Fork Bens Creek was sampled from October 1984 through February 1986. Funding was not available for a two-site stormflow sampling program during the first year of study. During the second year of study both sites were to be sampled concurrently so variations in chemical response between the sites could be compared. However, the installation of a production well within the South Fork Bens Creek basin, as previously discussed, compromised the water-quality data for that site. None of the other first order streams in the area could be substituted to do concurrent sampling. 
The stormflow sampling aspect of this study was done to provide evidence of stream chemistry change using only physical and chemical data collected from each stream. An in-depth interpretation with conclusions based on geochemical stability, solubility, and dissolution kinetic relationships cannot be made because no soilwater, ground water, or solid-phase data were collected. Consequently, much uncertainty exists about the nature of acid precipitation in relation to the weathering of soils and bedrock. In addition, it must be realized that although the theme of the following discussion is directed towards exogenous sources of chemical constituents to the basins, there are a number of endogenous sources that were not investigated.

\section{Relations Among $\mathrm{pH}$, Chemical Concentration, and Discharge}

The analyses of 14 rainfall and snowmelt runoff events in the South Fork and North Fork Bens Creek basins show that their response to such events with respect to discharge is similar despite some differences in bedrock, soils, and other characteristics in the basins. The magnitude of the response, as measured by the change in concentration of hydrogen ions, aluminum, nitrate, sulfate, chloride, iron, and manganese, appears to depend on the degree of saturation of the unconsolidated zone in addition to other factors, such as season, magnitude and duration of rainfa1l, and weather pattern.

Throughout the study, $\mathrm{pH}$ was related inversely to runoff (figs. 17 and 18). The decreases in $\mathrm{pH}$ during periods of rapid, short-duration thunderstorm runoff were smaller than the decreases during prolonged snowmelt runoff.

Recovery of $\mathrm{pH}$ to prerunoff values from peak discharge values depended on the magnitude and type of precipitation event. Generally, $\mathrm{pH}$ recovery for storms of short duration was related directly to discharge recovery, whereas $\mathrm{pH}$ recovery for rainfall and snowmelt of long duration took as long as one week after discharge receded to base flow. During the initial stages of major runoff events, $\mathrm{pH}$ increased slightly before decreasing. Repeated recurrence of this phenomenon suggest that water "pooled" within the unconsolidated zone during gradual ice and snow melt lost much of its hydrogen ion content as a result of extended residence in the deeper soil horizons and then was displaced by the initial volumes of storm water. Examples of streamflow response during runoff events at South Fork and North Fork Bens Creek are illustrated in figure 19. 


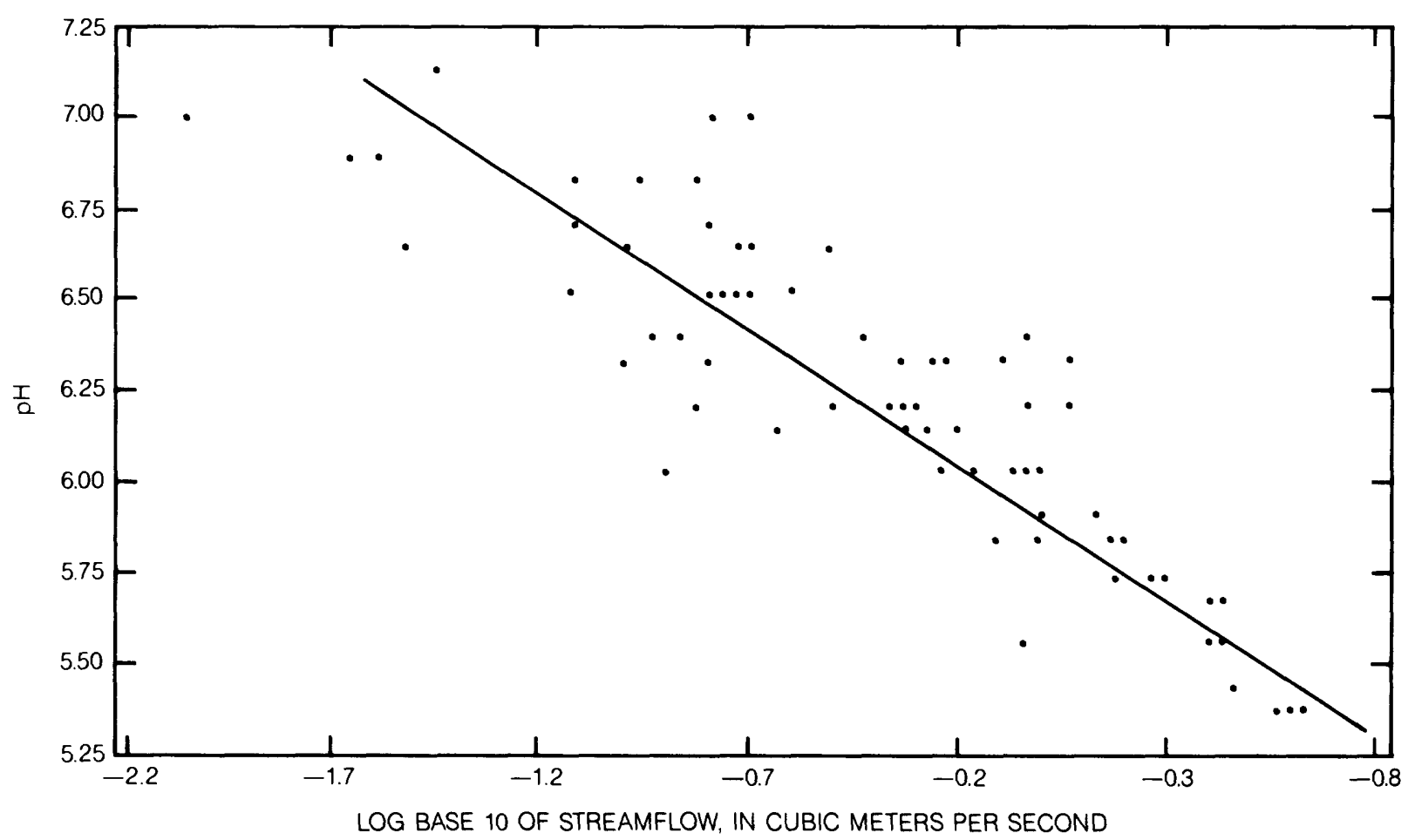

Figure 17.--Relation between streamflow and pH for the South Fork Bens Creek near Thomasdale.

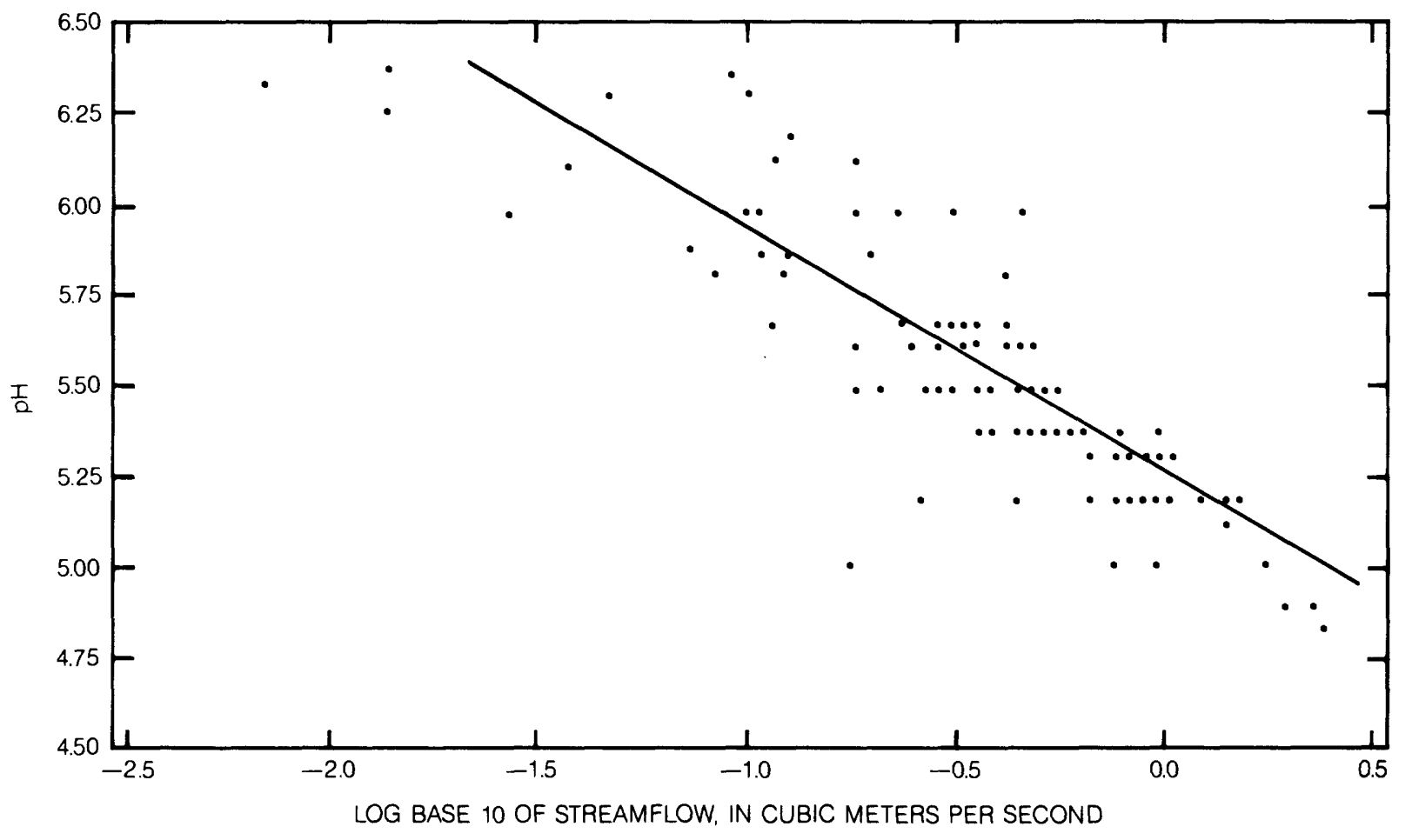

Figure 18.--Relation between streamflow and $\mathrm{pH}$ for the North Fork Bens Creek at North Fork Reservoir. 
Concentrations of aluminum, iron, and manganese were related directly to discharge, whereas chloride concentrations and $\mathrm{pH}$ were related inversely to discharge. Aluminum concentrations increased the most during long-duration rainfall episodes that came from the west. Dissolved aluminum reached concentration potentially toxic to fish in four of the five streams at least once during the 2 1/2-year study period.

The sum of base cations decreased during peak runoff periods for four of the six storms on the South Fork Bens Creek. The sum of base cations slightly increased during the peak of snowmelt and rainfall runoff of April 4-7, 1984 (fig. 19-B). The results from the May 2-3, 1985 event (fig. 19-E) deviated from the response trends.

Base cations for the North Fork Bens Creek responded similarly (figs. 19-G thru M). Concentrations of the base cations and silica decreased during the peak runoff in seven of eight events. The March 12-13, 1985 (fig. 19-I) event was a short-duration, low-magnitude storm; therefore, increased concentrations of base cations and silica during peak flow could result from "flushing" of the unconsolidated zone. This "flushing" or displacement is similar to that described by Edwards (1973) and Walling and Foster (1975). The "flushing effect" is not uncommon, particularly during autumn, when the decrease in concentrations may be preceded by a rise or an initial drop may be followed by an increase before giving way to a subsequent decrease (Walling and Foster, 1975). The "flushing effect" observed in this study is discussed later in the report.

Sulfate concentration generally was related directly to discharge during all rainfall events, but no such relation was observed during snowmelt runoff. The response of sulfate concentrations to discharge was similar to that of other constituents studied in that the magnitude of discharge did not dictate the magnitude of change in concentration. Concentrations of sulfate increased during runoff events preceded by a prolonged period of dry weather (figs. 19-C and G), probably because of the washout of dry deposition that built up on the soils and vegetation during the extended dry periods. The elevated densities of sulfur dioxide emitted to the atmosphere west of the study area (fig. 2) correlates well with the elevated percentages of sulfate found in the wet deposition samples. Statistical analysis of sulfate and $\mathrm{pH}$ on an event basis has shown significant correlation for all runoff episodes. Therefore, sulfuric acid was determined to be the largest contributor of hydrogen ion to stream acidity during rainfall runoff.

Nitrate concentrations generally did not increase during any of the rainfall/runoff episodes. In some instances nitrate decreased during episodic discharge. However, nitrate concentrations did increase during one period of snowmelt runoff (fig. 19-M) and was significantly correlated with $\mathrm{pH}$. Nitrate concentrations have been shown to be greater than sulfate concentrations in snowpacks near the study area (DeWalle and others, 1983). Therefore, nitric acid contributes to stream acidity during snowmelt runoff. Sources of nitrate within the snowpack were not examined; however, they are believed to be a combination of atmospheric inputs, leaf-litter leachate, and microbial action within the detrital layer beneath the snowpack. Graphic presentations and data tables of all runoff events sampled are shown in figure 19 and tables 14 and 15 . 

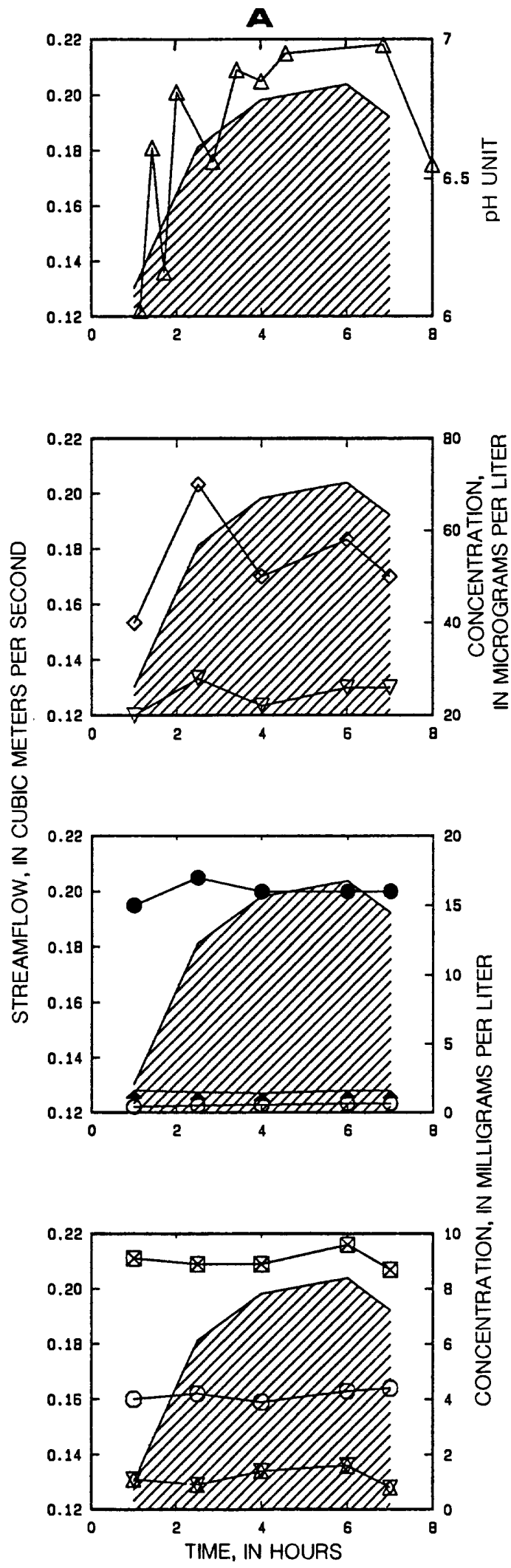

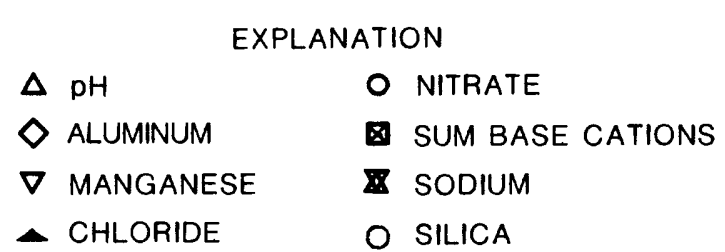

- sulfate
Figure 19.--Chemical changes in streamflow resulting from inputs of: (A) rainfall runoff November 10, 1983, South Fork Bens Creek. 

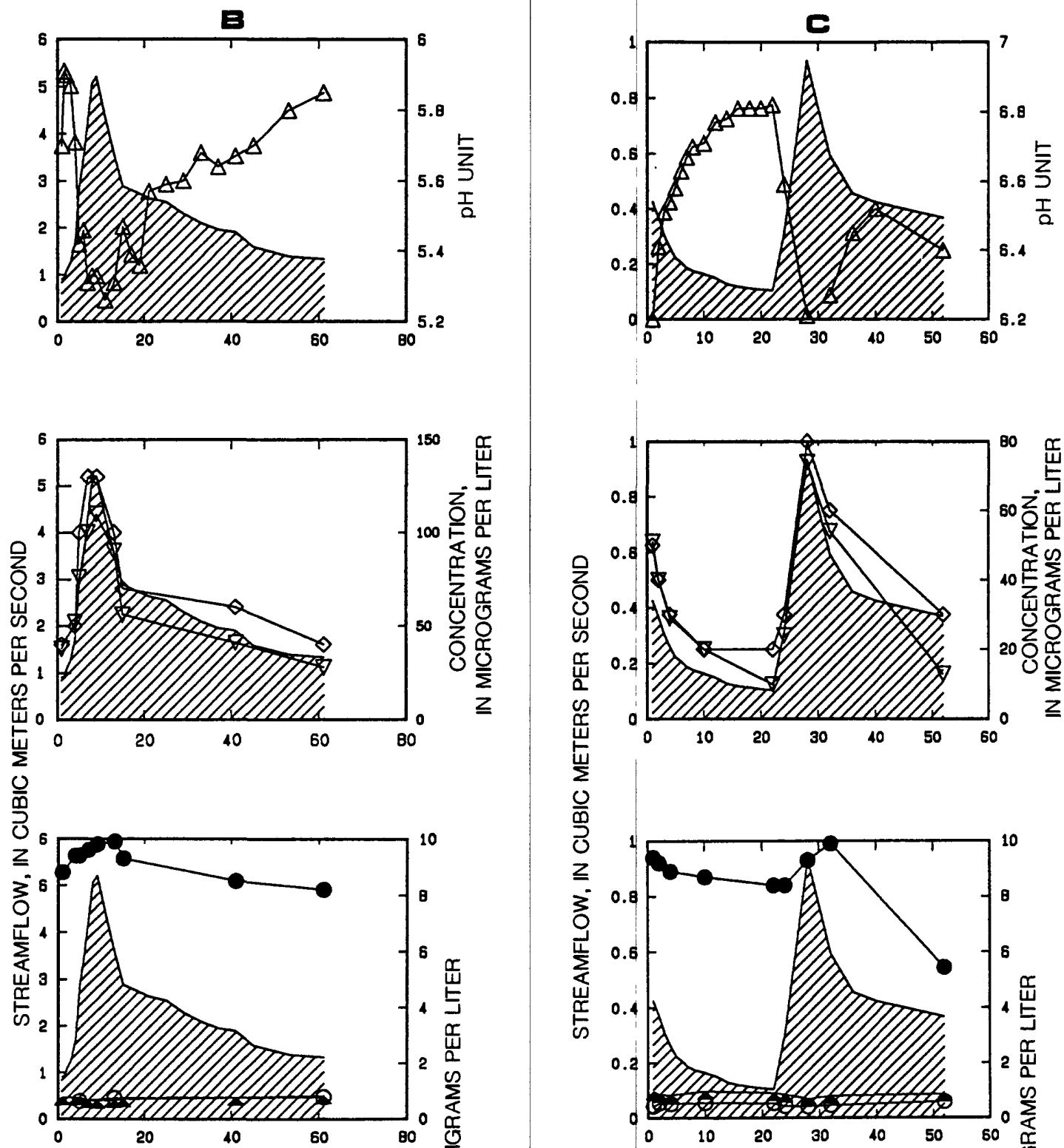

录

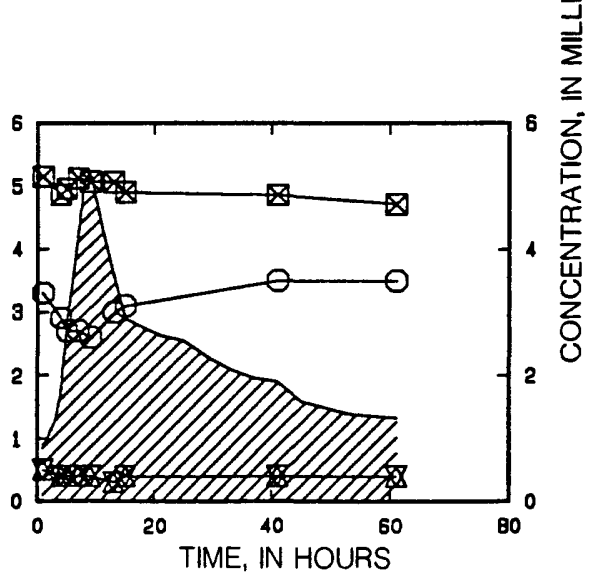

EXPLANATION
$\triangle \quad \mathrm{pH}$
$\nabla$ MANGANESE
SULFATE
\ SUM BASE CATIONS
$\checkmark$ ALUMINUM
- CHLORIDE
o nitrate
SO SODIUM 

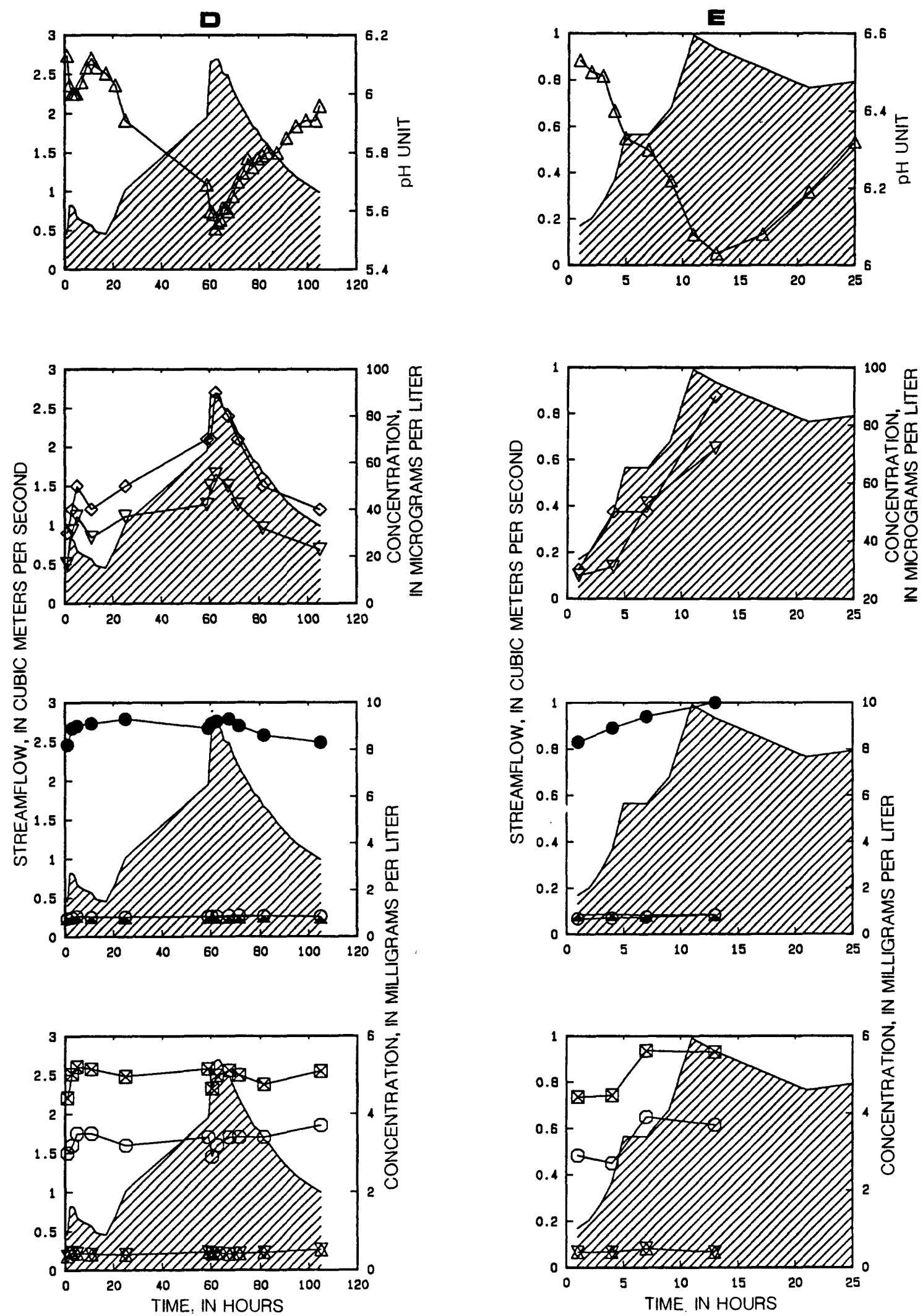

Figure 19.--Chemical changes in streamflow resulting from inputs of:

(B) snowmelt and rainfall runoff April 4-7, 1984 South Fork Bens Creek:

(C) rainfall runoff June 17-20, 1984, South Fork Bens Creek;

(D) rainfall runoff March 29 to April 2, 1985, South Fork Bens Creek;

(E) rainfall runoff May 2-3, 1985, South Fork Bens Creek--Continued. 

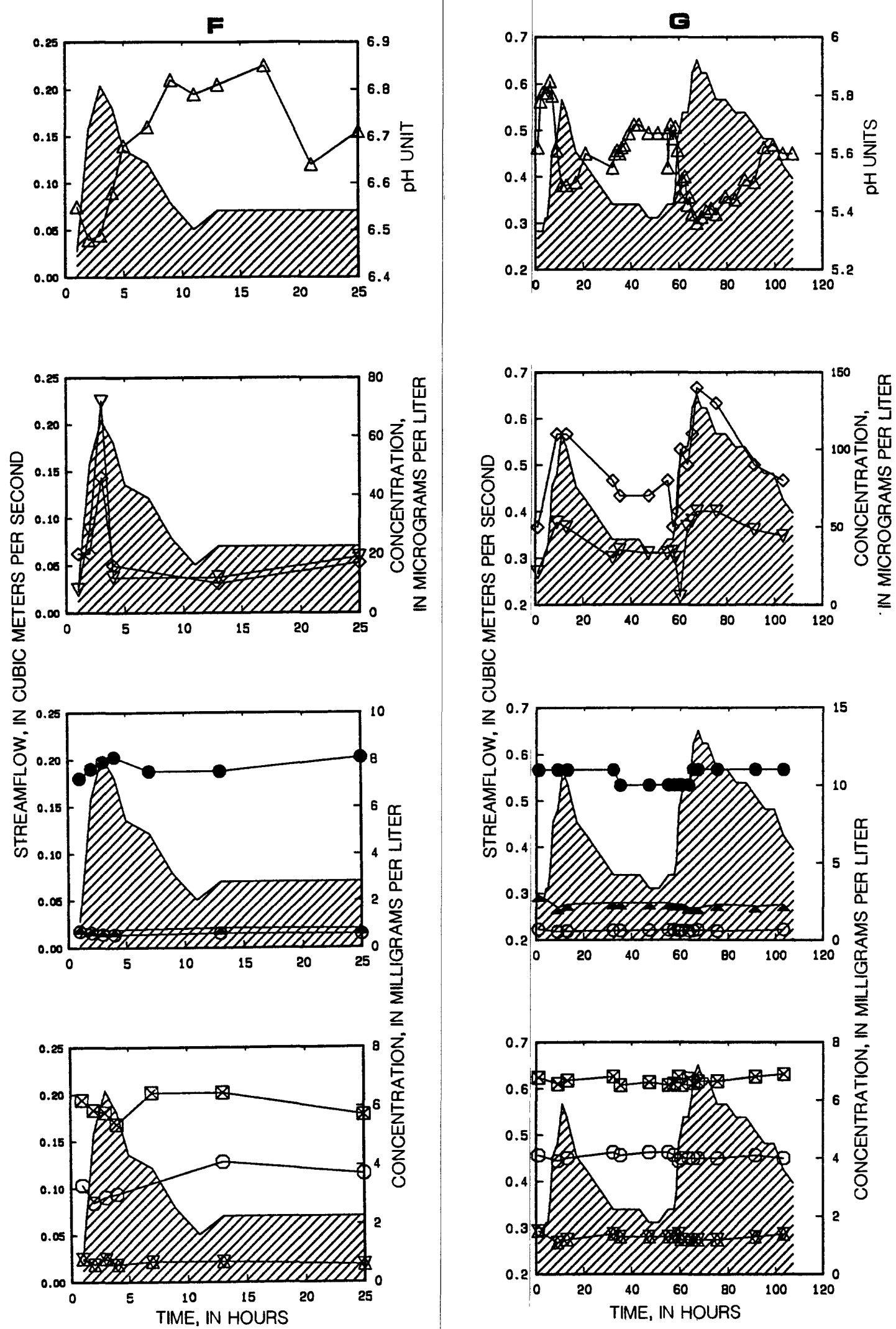

EXPLANATION
$\Delta \mathrm{pH}$
$\nabla$ MANGANESE
SULFATE
$\triangle$ SUM BASE CATIONS
$\diamond$ ALUMINUM - CHLORIDE
- nitrate
$\$$ SODIUM
O SILICA 

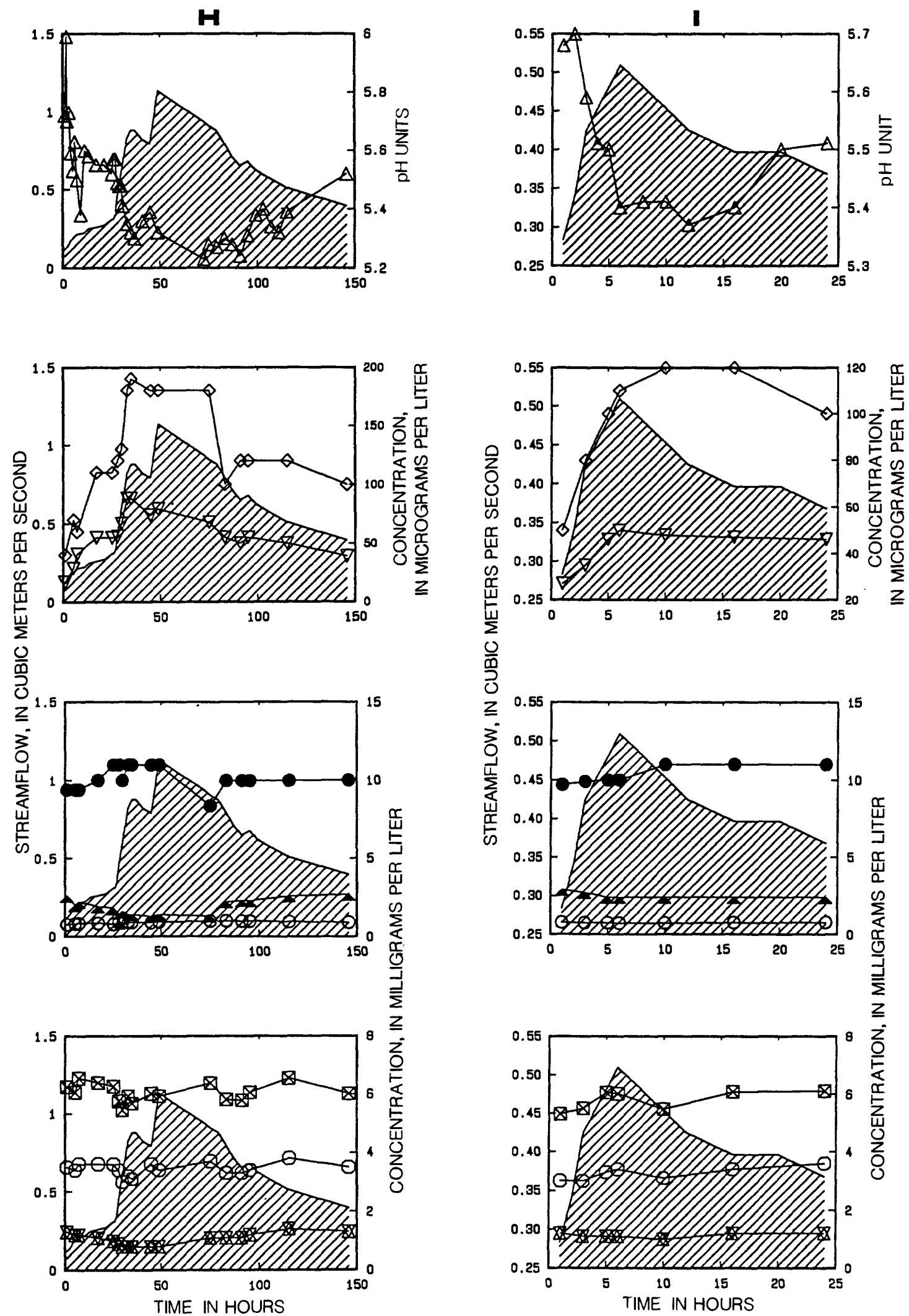

Figure 19.--Chemical changes in streamflow resulting from inputs of:

(F) rainfall runoff July 21-22, 1985, South Fork Bens Creek;

(G) rainfall runoff December $19-21$ and 21-23, 1984, North Fork Bens Creek;

(H) snowmelt runoff February 22 to March 1, 1985, North Fork Bens Creek;

(I) rainfall runoff March 12-13, 1985, North Fork Bens Creek-- Continued. 

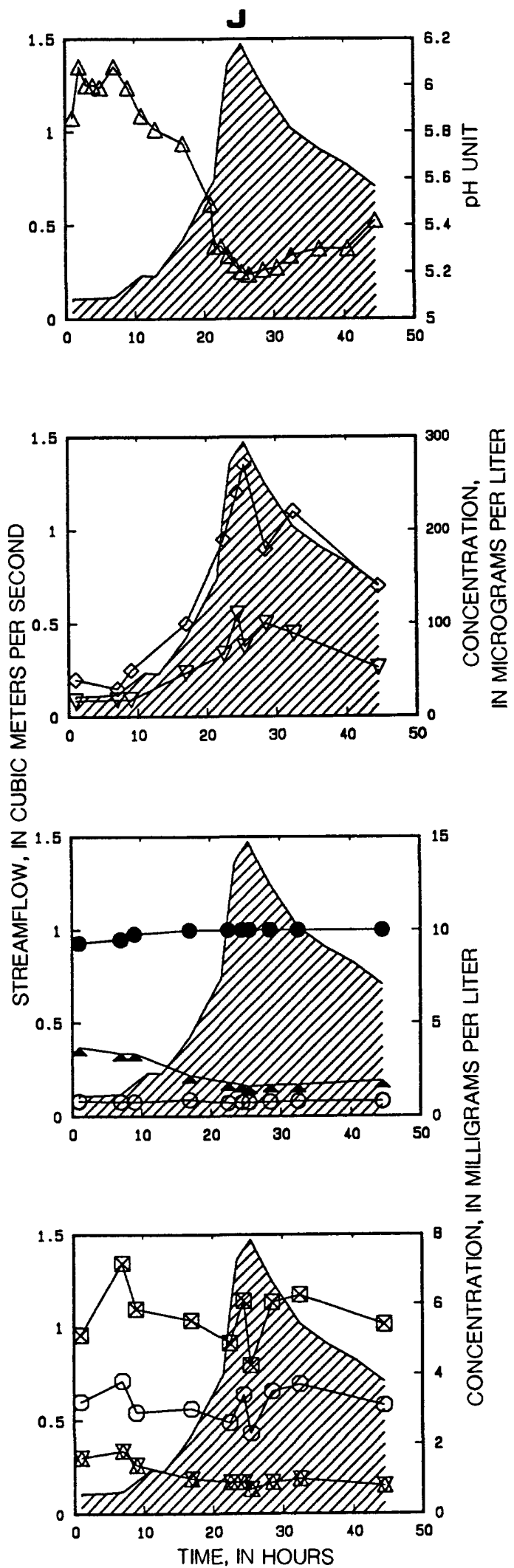
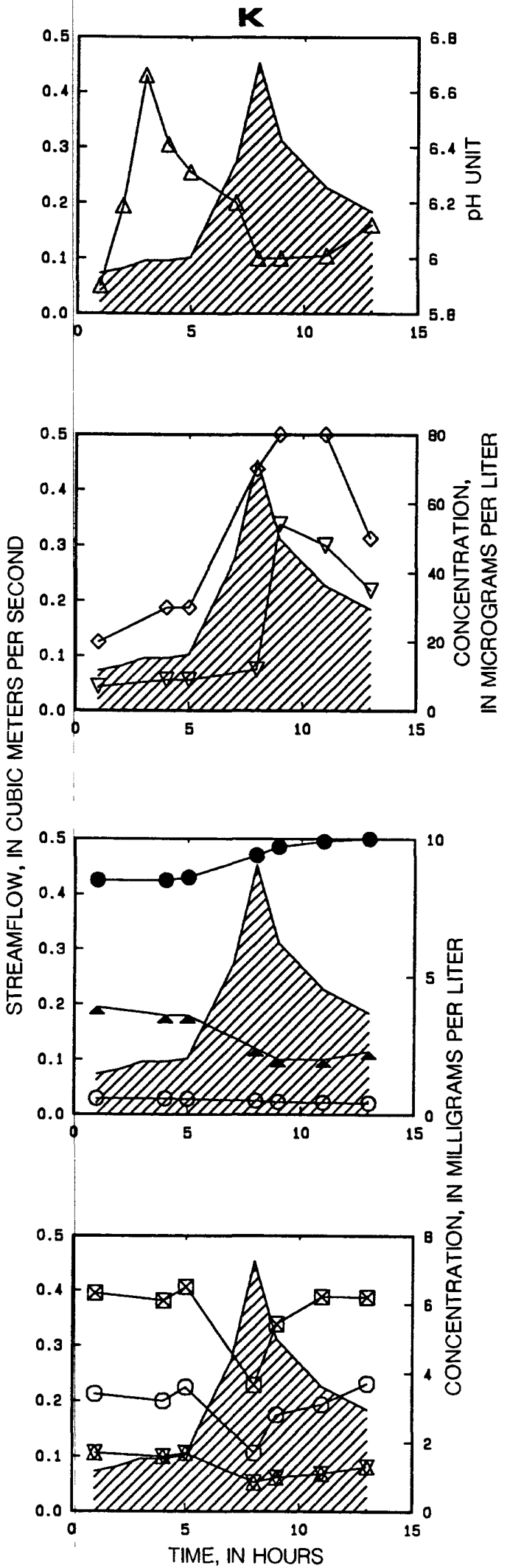

EXPLANATION
$\triangle \mathrm{pH}$
$\nabla$ MANGANESE
SULFATE
$\triangle$ SUM BASE CATIONS
$\diamond$ ALUMINUM
- CHLORIDE
- Nitrate
$\$$ SODIUM
O SILICA 

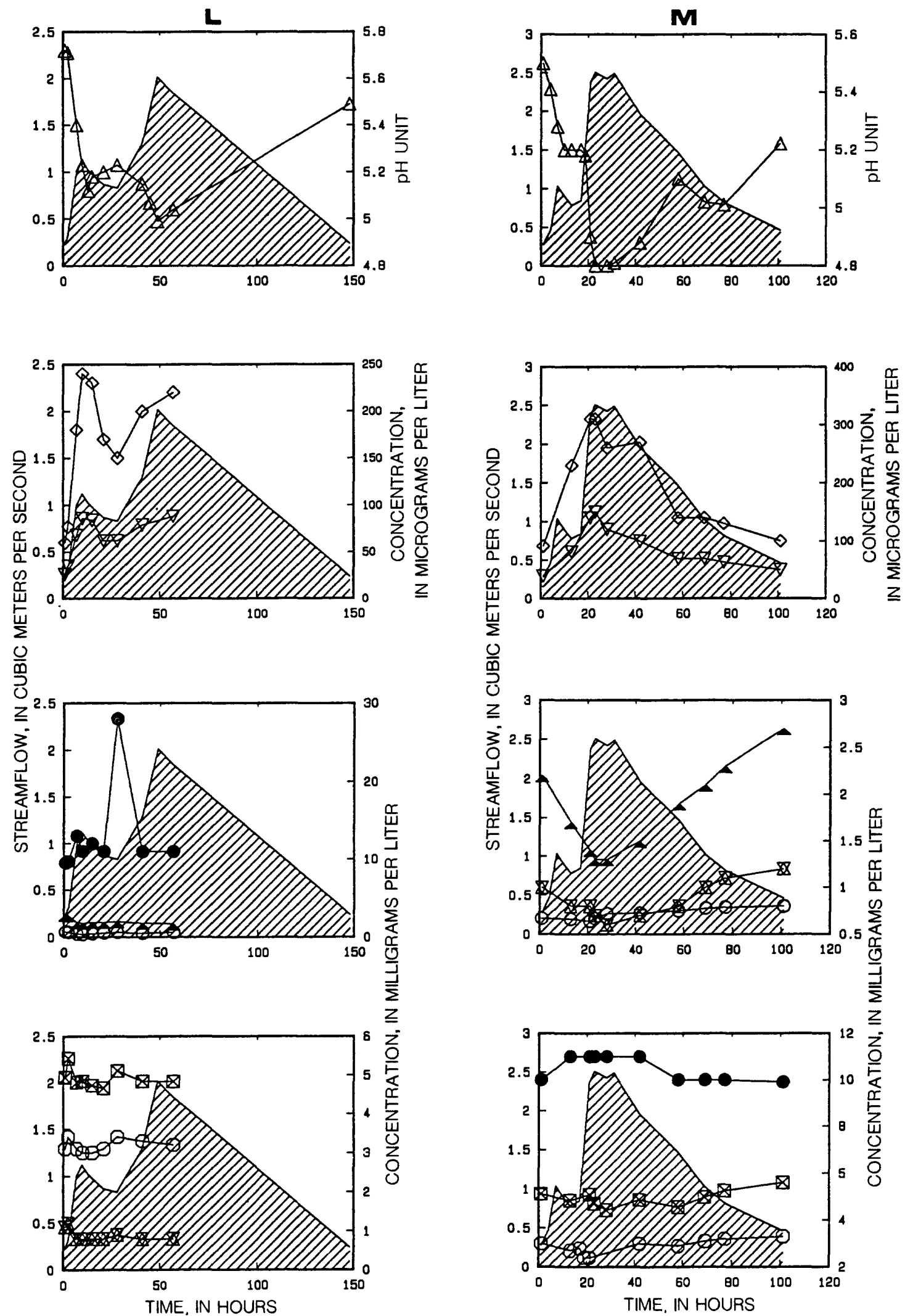

Figure 19.--Chemical changes in streamflow resulting from inputs of:

(J) rainfall runoff May 2-4, 1985, North Fork Bens Creek;

(K) rainfall runoff July $8-9,1985$, North Fork Bens Creek:

(L) rainfall runoff November 26-28, 1985, North Fork Bens Creek:

(M) snowmelt runoff February 4-8, 1986, North Fork Bens Creek -Continued. 
Table 14.--Water-quality data for rainfall and snownelt runoff at South Fork Bens Creek near Thomasdale, 1983-86

$\left[\mathrm{m}^{3} / \mathrm{s}\right.$, cubic meters per second; $\mu \$ / \mathrm{cm}$, microsiemens per centimeter at 25 degrees Celsius; mg/L, milligrums per 1iter; $\mu g / L$, micrograms per liter; <, less than; --. indicates no data]

\begin{tabular}{|c|c|c|c|c|c|c|c|c|c|c|c|}
\hline Date & Time & $\begin{array}{l}\text { Stream- } \\
\text { flow, } \\
\text { instan- } \\
\text { taneous } \\
\left(\mathrm{m}^{3} / \mathrm{s}\right)\end{array}$ & $\begin{array}{l}\text { Spe- } \\
\text { cific } \\
\text { con- } \\
\text { duct- } \\
\text { ance } \\
(\mu S / \mathrm{cm})\end{array}$ & $\begin{array}{l}\text { pH } \\
\text { (stand- } \\
\text { ard } \\
\text { units) }\end{array}$ & $\begin{array}{l}\text { Acidity } \\
\text { (mg/L } \\
\text { as } \mathrm{B}^{+} \text {) }\end{array}$ & $\begin{array}{l}\text { Calcium, } \\
\text { dis- } \\
\text { solved } \\
\text { (ng/L) }\end{array}$ & $\begin{array}{l}\text { Magne- } \\
\text { Bium, } \\
\text { dis- } \\
\text { solved } \\
\text { (mg/L) }\end{array}$ & $\begin{array}{l}\text { Sodium, } \\
\text { dis- } \\
\text { solved } \\
\text { (mg/L) }\end{array}$ & $\begin{array}{l}\text { Potas- } \\
\text { sium, } \\
\text { dis- } \\
\text { solved } \\
\text { (mg/L) }\end{array}$ & $\begin{array}{l}\text { Alka- } \\
\text { linity, } \\
\text { lab } \\
(\mathrm{mg} / \mathrm{L} \\
\text { as } \\
\left.\mathrm{CaCO}_{3}\right)\end{array}$ & $\begin{array}{l}\text { Sulfate, } \\
\text { dis- } \\
\text { solved } \\
\text { (mg/L) }\end{array}$ \\
\hline NOV & & & & & & 1983 & 1 & & & & \\
\hline $\begin{array}{l}10 \\
10 \\
10 \\
10 \\
10 \\
10 \\
10 \\
10 \\
10 \\
10 \\
10 \\
10\end{array}$ & $\begin{array}{l}1500 \\
1515 \\
1530 \\
1545 \\
1600 \\
1630 \\
1700 \\
1730 \\
1800 \\
1900 \\
2000 \\
2100\end{array}$ & $\begin{array}{r}0.13 \\
\overline{-} \\
.15 \\
=- \\
-- \\
.18 \\
=- \\
=- \\
.20 \\
=- \\
.20 \\
.19\end{array}$ & $\begin{array}{l}54 \\
53 \\
56 \\
58 \\
-- \\
54 \\
57 \\
59 \\
57 \\
-- \\
59 \\
60\end{array}$ & $\begin{array}{c}6.02 \\
6.61 \\
6.16 \\
6.81 \\
-- \\
6.56 \\
6.89 \\
6.85 \\
6.95 \\
-.- \\
6.98 \\
6.55\end{array}$ & $\begin{array}{c}<0.1 \\
-. \\
<.1 \\
-- \\
-- \\
-.1 \\
-- \\
.1 \\
<.1 \\
<.1\end{array}$ & $\begin{array}{l}6.5 \\
-- \\
-- \\
-- \\
-- \\
6.5 \\
-- \\
-- \\
6.1 \\
-- \\
6.4 \\
6.3\end{array}$ & $\begin{array}{l}1.5 \\
-- \\
-- \\
-- \\
-- \\
1.5 \\
-- \\
-- \\
1.4 \\
-\overline{1.6} \\
1.6\end{array}$ & $\begin{array}{c}1.1 \\
-- \\
-- \\
-- \\
-- \\
.90 \\
-- \\
-- \\
1.4 \\
-- \\
1.6 \\
.80\end{array}$ & $\begin{array}{l}-- \\
-- \\
-- \\
-- \\
-- \\
1.1 \\
-- \\
-- \\
-- \\
-- \\
-- \\
--\end{array}$ & $\begin{array}{c}10.0 \\
=- \\
=- \\
-- \\
-- \\
9.0 \\
-- \\
-- \\
10.0 \\
-- \\
9.0 \\
8.0\end{array}$ & $\begin{array}{l}15 \\
-- \\
-- \\
-- \\
-- \\
17 \\
-- \\
-- \\
16 \\
-- \\
16 \\
16\end{array}$ \\
\hline Date & $\begin{array}{l}\text { Chlo- } \\
\text { ride, } \\
\text { dis- } \\
\text { solved } \\
\text { (mg/L) }\end{array}$ & $\begin{array}{l}\text { Fluo- } \\
\text { ride, } \\
\text { dis- } \\
\text { solved } \\
\text { (ms/L) }\end{array}$ & $\begin{array}{l}\text { Bromide, } \\
\text { dis- } \\
\text { solved } \\
\text { (mg/L) }\end{array}$ & $\begin{array}{l}\text { Silica, } \\
\text { dis- } \\
\text { solved } \\
(\mathrm{mg} / \mathrm{L})\end{array}$ & $\begin{array}{l}\text { Nitro- } \\
\text { gen } \\
\text { ammonia, } \\
\text { dis- } \\
\text { solved } \\
\text { (mg/L } \\
\text { as N) }\end{array}$ & $\begin{array}{l}\text { Phos- } \\
\text { phorus, } \\
\text { ortho, } \\
\text { dis- } \\
\text { solved } \\
\text { (mg/L) }\end{array}$ & $\begin{array}{l}\text { Alum- } \\
\text { Inum, } \\
\text { dis- } \\
\text { solved } \\
(\mu \& / L)\end{array}$ & $\begin{array}{l}\text { Iron, } \\
\text { dis- } \\
\text { solved } \\
(\mu g / L)\end{array}$ & $\begin{array}{l}\text { Manga- } \\
\text { nese, } \\
\text { dis- } \\
\text { solved } \\
(\mu g / L)\end{array}$ & $\begin{array}{l}\text { Carbon, } \\
\text { organic, } \\
\text { dis- } \\
\text { solved } \\
\text { (ms/L) }\end{array}$ & $\begin{array}{l}\text { Nitrogen } \\
\text { nitrate, } \\
\text { dissolved } \\
\text { (mg/L } \\
\text { as } N \text { ) }\end{array}$ \\
\hline \multicolumn{12}{|l|}{ Nov } \\
\hline $\begin{array}{l}10 \\
10 \\
10 \\
10 \\
10 \\
10 \\
10 \\
10 \\
10 \\
10 \\
10 \\
10\end{array}$ & $\begin{array}{r}1.6 \\
-. \\
-- \\
-- \\
-- \\
1.5 \\
-- \\
-- \\
1.4 \\
-. \\
1.6 \\
1.6\end{array}$ & $\begin{array}{l}0.01 \\
-- \\
-- \\
-- \\
-- \\
.09 \\
-- \\
-- \\
<.01 \\
-- \\
.09 \\
.07\end{array}$ & $\begin{array}{l}<0.1 \\
-- \\
-- \\
-- \\
-- \\
<.1 \\
-- \\
-- \\
<.1 \\
-- \\
<.1 \\
<.1\end{array}$ & $\begin{array}{c}4.0 \\
-- \\
-- \\
-- \\
-- \\
4 . .2 \\
-- \\
-- \\
3.9 \\
-- \\
4.3 \\
4.4\end{array}$ & $\begin{array}{c}0.018 \\
-- \\
.019 \\
-- \\
-- \\
.042 \\
-- \\
-- \\
.198 \\
\overline{-065} \\
.029\end{array}$ & $\begin{array}{c}<0.06 \\
<.001 \\
-.0 \\
<.06 \\
- \\
<.06 \\
<.06 \\
<.06\end{array}$ & $\begin{array}{l}40 \\
-- \\
-- \\
-- \\
-- \\
70 \\
-7 \\
=- \\
50 \\
-7 \\
58 \\
50\end{array}$ & $\begin{array}{l}36 \\
-- \\
-- \\
-- \\
-- \\
33 \\
-- \\
-- \\
40 \\
-- \\
27 \\
25\end{array}$ & $\begin{array}{l}20 \\
-- \\
-- \\
-- \\
-- \\
28 \\
-- \\
-- \\
22 \\
-- \\
26 \\
26\end{array}$ & $\begin{array}{r}4.0 \\
-- \\
3.6 \\
-- \\
-- \\
3.4 \\
-- \\
-- \\
4.3 \\
-- \\
3.6 \\
4.2\end{array}$ & $\begin{array}{l}0.41 \\
-- \\
-- \\
-- \\
-- \\
.54 \\
-- \\
-- \\
.55 \\
-- \\
.66 \\
.67\end{array}$ \\
\hline
\end{tabular}


Table 14.--Water-quality data for rainfall and snowmelt runoff at South Fork Bens Creek near Thomasdale, 1983-86--Continued

$\mathrm{lm}^{3} / \mathrm{s}$, cubic meters per second; $\mu \mathrm{S} / \mathrm{cm}$, microsiemens per centimeter at 25 degrees Celsius; mg/L, milligrams per liter; $\mu \mathrm{g} / \mathrm{L}$, micrograms per liter; <, less than; --, indicates no data]

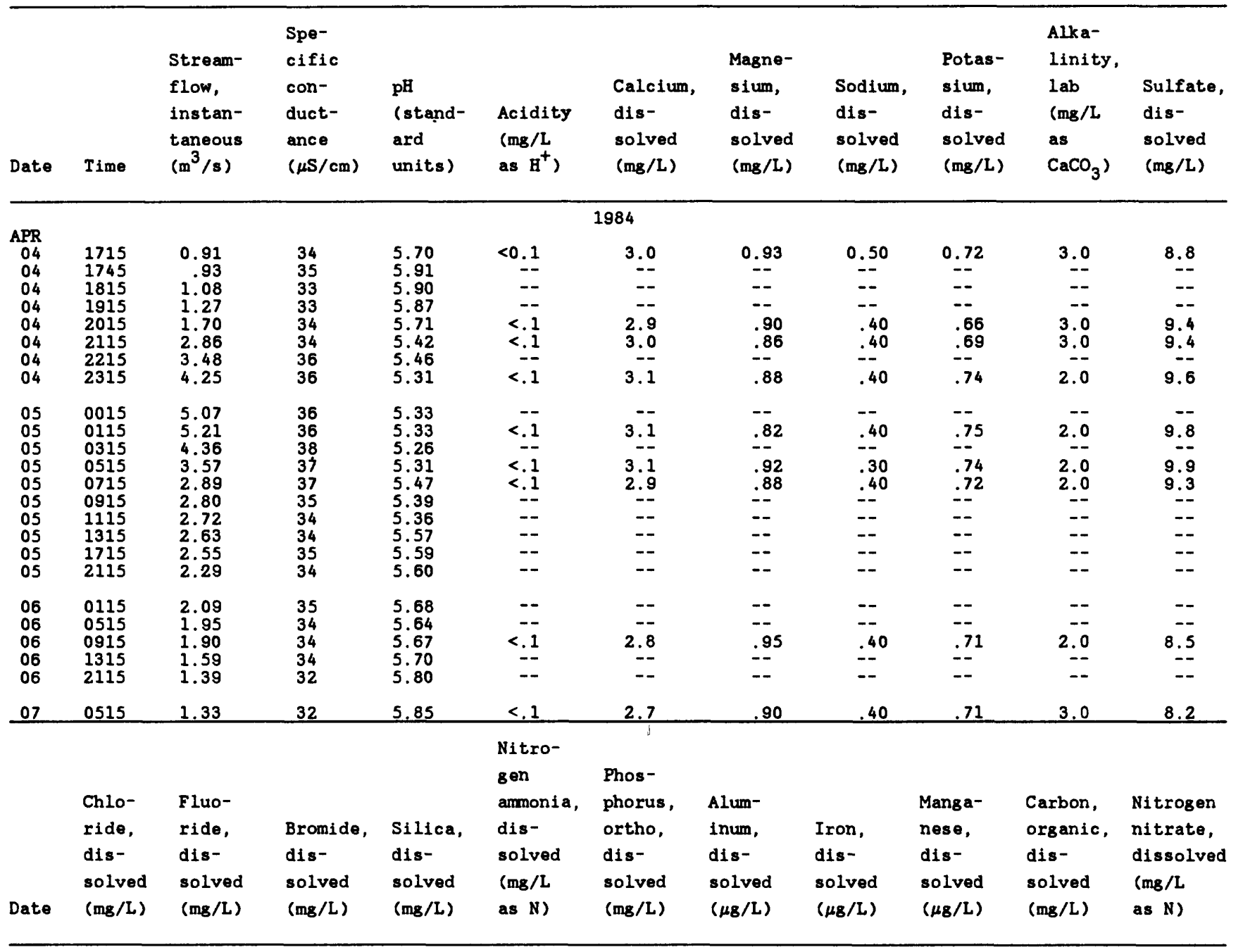

\begin{tabular}{|c|c|c|c|c|c|c|c|c|c|c|c|}
\hline \multicolumn{12}{|l|}{ APR } \\
\hline 04 & 0.78 & $<0.01$ & $<0.1$ & 3.3 & 0.062 & $<0.06$ & 40 & 27 & 38 & 1.5 & -- \\
\hline 04 & -- & -- & -- & - & -- & -- & -- & $=-$ & -- & - & -- \\
\hline 04 & -- & -- & -- & -- & -- & -- & -- & - & -- & -- & -- \\
\hline 04 & -- & -- & -- & -- & -- & -- & -- & -- & -- & -- & -- \\
\hline 04 & .77 & .04 & $<.1$ & 2.9 & .157 & $<.06$ & 50 & 14 & 52 & 3.7 & $\ldots$ \\
\hline 04 & .78 & .05 & 1 & 2.7 & $=-$ & $<.06$ & 100 & 18 & 76 & $=$ & 0.64 \\
\hline 04 & -- & -- & $=$ & - & -- & -- & -- & -- & -- & -- & $=$ \\
\hline 04 & .67 & .06 & $<.1$ & 2.7 & .180 & $<.06$ & 130 & 35 & 100 & 2.6 & -- \\
\hline 05 & -- & -- & -- & -- & -- & -- & -- & -- & -- & -- & - \\
\hline 05 & .66 & .04 & $<.1$ & 2.6 & .161 & $<.06$ & 130 & 18 & 110 & 2.2 & -- \\
\hline 05 & -- & -- & -- & - & -- & -- & - & -- & -- & - & -- \\
\hline 05 & .68 & .06 & $<.1$ & 3.0 & .047 & $<.06$ & 100 & 17 & 90 & 2.0 & .75 \\
\hline 05 & .72 & .05 & $<.1$ & 3.1 & -- & $<.06$ & 70 & 6 & 56 & - & -- \\
\hline 05 & -- & -- & -- & -5 & -- & -- & -- & -- & -- & -- & -- \\
\hline 05 & -- & -- & -- & -- & -- & -- & -- & -- & -- & -- & -- \\
\hline 05 & -- & -- & -- & -- & -- & -- & -- & -- & -- & -- & - \\
\hline 05 & -- & -- & -- & -- & -- & -- & -- & -- & -- & -- & -- \\
\hline 05 & -- & -- & -- & -- & -- & -- & -- & -- & -- & -- & -- \\
\hline 06 & -- & -- & -- & -- & -- & -- & -- & -- & -- & -- & -- \\
\hline 06 & -- & -- & -- & -- & -- & -- & -- & -- & -- & -- & - \\
\hline 06 & .77 & -- & $<.1$ & 3.5 & -- & $<.06$ & 60 & 10 & 41 & -- & -- \\
\hline 06 & -- & -- & -- & -- & -- & -- & -- & -- & -- & -- & -- \\
\hline 06 & -- & -- & -- & -- & -- & -- & -- & -- & -- & -- & -- \\
\hline 07 & .83 & $<.01$ & $<.01$ & 3.5 & .133 & $<.06$ & 40 & 5 & 28 & 1.1 & .79 \\
\hline
\end{tabular}


Table 14.--Water-quality data for rainfall ahd snowmelt runoff at South Fork Bens Creek near Thomasdale, 1983-86--Continupd

$\left[\mathrm{m}^{3} / \mathrm{s}\right.$, cublc meters per second; $\mu \mathrm{s} / \mathrm{cm}$, microsiemens per centimeter at 25 degrees Celsius; mg/L, milligrams per 11 ter; $\mu g / L$, micrograms per liter; <, less than; --, indicates no data]

\begin{tabular}{|c|c|c|c|c|c|c|c|c|c|c|c|}
\hline Date & Time & $\begin{array}{l}\text { Stream- } \\
\text { flow, } \\
\text { Instan- } \\
\text { taneous } \\
\left(\mathrm{m}^{3} / \mathrm{s}\right)\end{array}$ & $\begin{array}{l}\text { Spe- } \\
\text { c1f1c } \\
\text { con- } \\
\text { duct- } \\
\text { ance } \\
(\mu S / c m)\end{array}$ & $\begin{array}{l}\text { pH } \\
\text { (stand- } \\
\text { ard } \\
\text { units) }\end{array}$ & $\begin{array}{l}\text { Acidity } \\
\left(\mathrm{mg}_{\mathrm{g}} / \mathrm{L}\right. \\
\text { as } \mathrm{H}^{+} \text {) }\end{array}$ & $\begin{array}{l}\text { Calcium, } \\
\text { dis- } \\
\text { solved } \\
\text { (ng/L) }\end{array}$ & $\begin{array}{l}\text { Magne- } \\
\text { sium, } \\
\text { d1s- } \\
\text { solved } \\
\text { (mg/L) }\end{array}$ & $\begin{array}{l}\text { Sodium, } \\
\text { dis- } \\
\text { solved } \\
(\mathrm{mg} / \mathrm{L})\end{array}$ & $\begin{array}{l}\text { Potas - } \\
\text { sium, } \\
\text { dis- } \\
\text { solved } \\
\text { (mg/L) }\end{array}$ & $\begin{array}{l}\text { Alka- } \\
\text { linlty, } \\
\text { lab } \\
(\mathrm{mg} / \mathrm{L} \\
\mathrm{as} \\
\left.\mathrm{CaCO}_{3}\right)\end{array}$ & $\begin{array}{l}\text { Sulfate, } \\
\text { dis- } \\
\text { solved } \\
\text { (mg/L) }\end{array}$ \\
\hline $\begin{array}{c}\text { JUNE } \\
17 \\
17\end{array}$ & $\begin{array}{l}2300 \\
2400\end{array}$ & $\begin{array}{r}0.42 \\
.37\end{array}$ & $\begin{array}{l}37 \\
35\end{array}$ & $\begin{array}{l}6.20 \\
6.41\end{array}$ & $\begin{array}{l}<0.1 \\
<0.1\end{array}$ & $\begin{array}{r}1984 \\
3.2 \\
3.3\end{array}$ & $\begin{array}{r}0.94 \\
.95\end{array}$ & $\begin{array}{r}0.50 \\
.50\end{array}$ & $\begin{array}{r}0.96 \\
.69\end{array}$ & $\begin{array}{l}3.0 \\
4.0\end{array}$ & $\begin{array}{l}9.4 \\
9.2\end{array}$ \\
\hline $\begin{array}{l}18 \\
18 \\
18 \\
18 \\
18 \\
18 \\
18 \\
18 \\
18 \\
18 \\
18 \\
18 \\
18 \\
18\end{array}$ & $\begin{array}{l}0100 \\
0200 \\
0300 \\
0400 \\
0500 \\
0600 \\
0800 \\
1000 \\
1200 \\
1400 \\
1600 \\
1800 \\
2000 \\
2200\end{array}$ & $\begin{array}{l}.31 \\
.26 \\
.22 \\
.21 \\
.19 \\
.18 \\
.16 \\
.15 \\
.13 \\
.12 \\
.11 \\
.11 \\
.10 \\
.31\end{array}$ & $\begin{array}{l}34 \\
34 \\
34 \\
34 \\
35 \\
35 \\
34 \\
34 \\
34 \\
34 \\
34 \\
34 \\
34 \\
34\end{array}$ & $\begin{array}{l}6.51 \\
6.54 \\
6.58 \\
6.63 \\
6.67 \\
6.70 \\
6.71 \\
6.77 \\
6.78 \\
6.81 \\
6.81 \\
6.81 \\
6.82 \\
6.59\end{array}$ & $\begin{array}{r}<0.1 \\
-- \\
-- \\
-- \\
<0.1 \\
-- \\
-- \\
-- \\
-- \\
<0.1 \\
<0.1\end{array}$ & $\begin{array}{l}-- \\
3.3 \\
=- \\
-- \\
-- \\
-- \\
3.4 \\
-- \\
-- \\
-- \\
-- \\
-- \\
3.3 \\
3.3\end{array}$ & $\begin{array}{l}-- \\
.96 \\
-- \\
-- \\
-- \\
-- \\
.96 \\
-- \\
-- \\
-- \\
-- \\
-- \\
1.0 \\
.95\end{array}$ & $\begin{array}{l}-- \\
.50 \\
-- \\
-- \\
-- \\
-- \\
.50 \\
-- \\
-- \\
-- \\
-- \\
-- \\
.50 \\
.50\end{array}$ & $\begin{array}{l}-- \\
.69 \\
-- \\
-- \\
-- \\
-- \\
.70 \\
-- \\
-- \\
-- \\
-- \\
-- \\
.72 \\
.87\end{array}$ & $\begin{array}{c}-- \\
4.0 \\
-- \\
-- \\
-- \\
-- \\
5.0 \\
-- \\
-- \\
-- \\
-- \\
4.0 \\
4.0\end{array}$ & $\begin{array}{c}-- \\
8.9 \\
-- \\
-- \\
-- \\
-- \\
8.7 \\
-- \\
-- \\
-- \\
-- \\
-- \\
8.4 \\
8.4\end{array}$ \\
\hline $\begin{array}{l}19 \\
19 \\
19 \\
19\end{array}$ & $\begin{array}{l}0200 \\
0600 \\
1000 \\
1400\end{array}$ & $\begin{array}{l}.93 \\
.59 \\
.46 \\
.42\end{array}$ & $\begin{array}{l}32 \\
33 \\
34 \\
33\end{array}$ & $\begin{array}{l}6.21 \\
6.27 \\
6.45 \\
6.52\end{array}$ & $\begin{array}{r}<0.1 \\
<0.1 \\
--\end{array}$ & $\begin{array}{c}3.1 \\
3.2 \\
-- \\
--\end{array}$ & $\begin{array}{l}.92 \\
.94 \\
-- \\
--\end{array}$ & $\begin{array}{l}.40 \\
.40 \\
-- \\
--\end{array}$ & $\begin{array}{l}.67 \\
.64 \\
-- \\
--\end{array}$ & $\begin{array}{c}3.0 \\
4.0 \\
-- \\
--\end{array}$ & $\begin{array}{c}9.3 \\
9.9 \\
-- \\
--\end{array}$ \\
\hline 20 & 0200 & .37 & 34 & 6.40 & $<0.1$ & 3.3 & .97 & .50 & .68 & 3.0 & 8.7 \\
\hline Date & $\begin{array}{l}\text { Chlo- } \\
\text { ride, } \\
\text { dis- } \\
\text { solved } \\
\text { (mg/L) }\end{array}$ & $\begin{array}{l}\text { Fluo- } \\
\text { ride, } \\
\text { d1s- } \\
\text { solved } \\
(\mathrm{mg} / \mathrm{L})\end{array}$ & $\begin{array}{l}\text { Bromide, } \\
\text { dis- } \\
\text { solved } \\
\text { (mg/L) }\end{array}$ & $\begin{array}{l}\text { Silica, } \\
\text { dis- } \\
\text { solved } \\
\text { (mg/L) }\end{array}$ & $\begin{array}{l}\text { Nitro- } \\
\text { gen } \\
\text { ammonia, } \\
\text { d1s- } \\
\text { solved } \\
\text { (ms/L } \\
\text { as N) }\end{array}$ & $\begin{array}{l}\text { Phos- } \\
\text { phorus, } \\
\text { ortho, } \\
\text { dis- } \\
\text { solved } \\
\text { (ms/L) }\end{array}$ & $\begin{array}{l}\text { Alum- } \\
\text { Inum, } \\
\text { dils- } \\
\text { sollved } \\
(\mu \mathrm{g} / \mathrm{L})\end{array}$ & $\begin{array}{l}\text { Iron, } \\
\text { dis- } \\
\text { solved } \\
(\mu g / L)\end{array}$ & $\begin{array}{l}\text { Manga- } \\
\text { nese, } \\
\text { d1s- } \\
\text { solved } \\
\left(\mu_{8} / L\right)\end{array}$ & $\begin{array}{l}\text { Carbon, } \\
\text { organ1c, } \\
\text { d1s- } \\
\text { solved } \\
\text { (mg/L) }\end{array}$ & $\begin{array}{l}\text { Nitrogen } \\
\text { nitrate, } \\
\text { dissolved } \\
\text { (mg/L } \\
\text { as } N \text { ) }\end{array}$ \\
\hline \multicolumn{12}{|l|}{ JUNE } \\
\hline $\begin{array}{l}17 \\
17\end{array}$ & $\begin{array}{r}0.96 \\
.84\end{array}$ & $\begin{array}{r}0.04 \\
.03\end{array}$ & $\begin{array}{l}<0.1 \\
<0.1\end{array}$ & $\begin{array}{l}3.5 \\
3.6\end{array}$ & -- & $\begin{array}{l}<.06 \\
<.06\end{array}$ & $\begin{array}{l}50 \\
40\end{array}$ & $\begin{array}{l}12 \\
13\end{array}$ & $\begin{array}{l}51 \\
40\end{array}$ & -- & $\begin{array}{r}0.43 \\
.54\end{array}$ \\
\hline $\begin{array}{l}18 \\
18 \\
18 \\
18 \\
18 \\
18 \\
18 \\
18 \\
18 \\
18 \\
18 \\
18 \\
18 \\
18\end{array}$ & $\begin{array}{l}-- \\
.83 \\
-- \\
-- \\
-- \\
-- \\
.97 \\
-- \\
-- \\
-- \\
-- \\
-- \\
.90 \\
.84\end{array}$ & $\begin{array}{l}-- \\
.03 \\
-- \\
-- \\
-- \\
-- \\
.05 \\
-- \\
-- \\
-- \\
-- \\
-- \\
.03 \\
.04\end{array}$ & $\begin{array}{c}-- \\
<0.1 \\
-- \\
-- \\
-- \\
-- \\
<0.1 \\
-- \\
-- \\
-- \\
-- \\
-- \\
<0.1 \\
<0.1\end{array}$ & $\begin{array}{c}-- \\
3.7 \\
-- \\
-- \\
-- \\
-- \\
3.9 \\
-- \\
-- \\
-- \\
-- \\
-- \\
3.9 \\
3.6\end{array}$ & $\begin{array}{l}-- \\
-- \\
-- \\
-- \\
-- \\
-- \\
-- \\
-- \\
-- \\
-- \\
-- \\
--\end{array}$ & $\begin{array}{c}-06 \\
<.06 \\
-- \\
<.06 \\
-- \\
-- \\
<.06 \\
<.06\end{array}$ & $\begin{array}{l}-- \\
30 \\
-- \\
-- \\
-- \\
\overline{-} \\
20 \\
-- \\
-- \\
-- \\
-- \\
30\end{array}$ & $\begin{array}{r}-- \\
8 \\
-- \\
-- \\
-- \\
-- \\
8 \\
-- \\
-- \\
-- \\
-- \\
-- \\
8 \\
20\end{array}$ & $\begin{array}{l}-- \\
29 \\
-- \\
-- \\
-- \\
-- \\
20 \\
-- \\
-- \\
-- \\
-- \\
-- \\
10 \\
24\end{array}$ & $\begin{array}{l}-- \\
-- \\
-- \\
-- \\
-- \\
-- \\
-- \\
-- \\
-- \\
-- \\
-- \\
-- \\
--\end{array}$ & $\begin{array}{l}-- \\
.51 \\
-- \\
-- \\
-- \\
-- \\
.55 \\
-- \\
-- \\
-- \\
-- \\
-- \\
.54 \\
1.03\end{array}$ \\
\hline $\begin{array}{l}19 \\
19 \\
19 \\
19\end{array}$ & $\begin{array}{l}.69 \\
.79 \\
-- \\
--\end{array}$ & $\begin{array}{l}.05 \\
.05 \\
-- \\
--\end{array}$ & $\begin{array}{l}<0.1 \\
<0.1 \\
--\end{array}$ & $\begin{array}{r}3.4 \\
3.7 \\
-- \\
--\end{array}$ & $\begin{array}{l}-- \\
-- \\
-- \\
--\end{array}$ & $\begin{array}{l}<.06 \\
<.06 \\
--\end{array}$ & $\begin{array}{l}80 \\
60 \\
--\end{array}$ & $\begin{array}{l}21 \\
10 \\
-- \\
--\end{array}$ & $\begin{array}{l}74 \\
54 \\
-- \\
--\end{array}$ & $\begin{array}{l}-- \\
-- \\
-- \\
--\end{array}$ & $\begin{array}{l}.41 \\
.46 \\
.-\end{array}$ \\
\hline 20 & .86 & .05 & $<0.1$ & 3.8 & -- & $<.06$ & 30 & 8 & 13 & -- & .59 \\
\hline
\end{tabular}


Table 14.--Water-quality data for rainfall and snowmelt runoff at South Fork Bens Creek near Thomasdale, 1983-86--Continued

$\left[\mathrm{m}^{3} / \mathrm{s}\right.$, cubic meters per second; $\mu \mathrm{S} / \mathrm{cm}$, microsiemens per centimeter at

25 degrees Celsius; mg/L, milligrams per liter; $\mu \mathrm{g} / \mathrm{L}$, micrograms per

liter; <, less than; --, indicates no data]

\begin{tabular}{|c|c|c|c|c|c|c|c|c|c|c|c|}
\hline Date & Time & $\begin{array}{l}\text { Stream- } \\
\text { flow, } \\
\text { instan- } \\
\text { taneous } \\
\left(\mathrm{m}^{3} / \mathrm{s}\right)\end{array}$ & $\begin{array}{l}\text { Spe- } \\
\text { cific } \\
\text { con- } \\
\text { duct- } \\
\text { ance } \\
(\mu S / \mathrm{cm})\end{array}$ & $\begin{array}{l}\mathrm{pH} \\
\text { (stand- } \\
\text { ard } \\
\text { units) }\end{array}$ & $\begin{array}{l}\text { Acidity } \\
(\mathrm{mg} / \mathrm{L} \\
\left.\text { as } \mathrm{B}^{+}\right)\end{array}$ & $\begin{array}{l}\text { Calcium, } \\
\text { dis- } \\
\text { solved } \\
\text { (mg/L) }\end{array}$ & $\begin{array}{l}\text { Magne- } \\
\text { sium, } \\
\text { dis- } \\
\text { solved } \\
\text { (mg/L) }\end{array}$ & $\begin{array}{l}\text { Sodium, } \\
\text { dis- } \\
\text { solved } \\
\text { (mg/L) }\end{array}$ & $\begin{array}{l}\text { Potas- } \\
\text { sium, } \\
\text { dis- } \\
\text { solved } \\
\text { (mg/L) }\end{array}$ & $\begin{array}{l}\text { Alka- } \\
\text { linity, } \\
\text { lab } \\
\left(\mathrm{mg}_{8} / \mathrm{L}\right. \\
\text { as } \\
\left.\mathrm{CaCO}_{3}\right)\end{array}$ & $\begin{array}{l}\text { Sulfate, } \\
\text { dis- } \\
\text { solved } \\
\text { (mg/L) }\end{array}$ \\
\hline \multicolumn{12}{|c|}{1985} \\
\hline $\begin{array}{l}29 \\
29 \\
29 \\
29 \\
29 \\
29 \\
29 \\
29 \\
29 \\
29\end{array}$ & $\begin{array}{l}0530 \\
0630 \\
0730 \\
0830 \\
0930 \\
1130 \\
1330 \\
1530 \\
1730 \\
2130\end{array}$ & $\begin{array}{r}0.45 \\
.82 \\
.82 \\
.79 \\
.68 \\
.62 \\
.59 \\
.57 \\
.48 \\
.45\end{array}$ & $\begin{array}{l}34 \\
34 \\
35 \\
34 \\
35 \\
35 \\
36 \\
36 \\
36 \\
36\end{array}$ & $\begin{array}{l}6.13 \\
6.03 \\
6.00 \\
6.00 \\
6.00 \\
6.04 \\
6.09 \\
6.12 \\
6.09 \\
6.07\end{array}$ & $\begin{array}{l}0.016 \\
=- \\
.018 \\
- \\
.016 \\
=- \\
.015 \\
=-\end{array}$ & $\begin{array}{r}2.6 \\
=-9 \\
2.9 \\
3.1 \\
- \\
3.1 \\
=-\end{array}$ & \begin{tabular}{c}
0.85 \\
.- \\
.94 \\
$-\square$ \\
1.0 \\
\hdashline- \\
1.0 \\
--
\end{tabular} & $\begin{array}{l}0.37 \\
-. \\
.47 \\
-5 \\
.43 \\
- \\
.41 \\
-.\end{array}$ & $\begin{array}{l}0.59 \\
-- \\
.71 \\
-- \\
.68 \\
-- \\
.64 \\
-- \\
--\end{array}$ & $\begin{array}{l}1.1 \\
-. \\
.60 \\
\because 70 \\
\therefore- \\
-- \\
.80 \\
--\end{array}$ & $\begin{array}{r}8.2 \\
-- \\
8.9 \\
-- \\
9.0 \\
-- \\
-- \\
9.1 \\
--\end{array}$ \\
\hline $\begin{array}{l}30 \\
30\end{array}$ & $\begin{array}{l}0130 \\
0530\end{array}$ & 1.71 & $\begin{array}{l}37 \\
36\end{array}$ & $\begin{array}{l}6.03 \\
5.91\end{array}$ & .017 & 3.0 & .94 & .40 & .62 & .50 & 9.3 \\
\hline $\begin{array}{l}31 \\
31 \\
31 \\
31 \\
31 \\
31 \\
31 \\
31 \\
31\end{array}$ & $\begin{array}{l}1530 \\
1700 \\
1800 \\
1900 \\
2000 \\
2100 \\
2200 \\
2300 \\
2400\end{array}$ & $\begin{array}{l}1.95 \\
2.66 \\
2.66 \\
2.69 \\
2.69 \\
2.63 \\
2.52 \\
2.49 \\
2.49\end{array}$ & $\begin{array}{l}36 \\
36 \\
38 \\
37 \\
37 \\
39 \\
37 \\
36 \\
38\end{array}$ & $\begin{array}{l}5.69 \\
5.60 \\
5.59 \\
5.54 \\
5.56 \\
5.57 \\
5.61 \\
5.61 \\
5.60\end{array}$ & $\begin{array}{l}.026 \\
.026 \\
-- \\
.024 \\
-- \\
-- \\
-- \\
-- \\
.024\end{array}$ & $\begin{array}{r}3.0 \\
2.7 \\
-- \\
2.9 \\
-- \\
- \\
- \\
- \\
3.0\end{array}$ & $\begin{array}{l}.96 \\
.85 \\
-- \\
.93 \\
-- \\
-- \\
-- \\
-- \\
.98\end{array}$ & $\begin{array}{l}.46 \\
.42 \\
-. \\
.43 \\
-. \\
-- \\
-- \\
.41\end{array}$ & $\begin{array}{l}.73 \\
.67 \\
-- \\
.72 \\
-- \\
-- \\
-- \\
.72\end{array}$ & $\begin{array}{l}.50 \\
.50 \\
-- \\
.50 \\
-- \\
=- \\
=- \\
.50\end{array}$ & $\begin{array}{r}8.9 \\
9.1 \\
-- \\
9.2 \\
-. \\
-- \\
=- \\
-- \\
9.3\end{array}$ \\
\hline \multicolumn{12}{|l|}{ APR } \\
\hline $\begin{array}{l}01 \\
01 \\
01 \\
01 \\
01 \\
01 \\
01 \\
01 \\
01 \\
01\end{array}$ & $\begin{array}{l}0200 \\
0400 \\
0600 \\
0800 \\
1000 \\
1200 \\
1400 \\
1600 \\
2000 \\
2400\end{array}$ & $\begin{array}{l}2.32 \\
2.18 \\
2.07 \\
1.95 \\
1.84 \\
1.78 \\
1.67 \\
1.61 \\
1.44 \\
1.30\end{array}$ & $\begin{array}{l}37 \\
37 \\
36 \\
36 \\
35 \\
36 \\
35 \\
35 \\
35 \\
35\end{array}$ & $\begin{array}{l}5.65 \\
5.70 \\
5.73 \\
5.78 \\
5.75 \\
5.78 \\
5.79 \\
5.80 \\
5.0 \\
5.85\end{array}$ & $\begin{array}{l}=- \\
.020 \\
=- \\
-- \\
- \\
.016 \\
--\end{array}$ & $\begin{array}{c}-- \\
-- \\
2.9 \\
-- \\
-- \\
-- \\
2.7 \\
-- \\
--\end{array}$ & $\begin{array}{l}-- \\
-- \\
.95 \\
-- \\
-- \\
-- \\
.90 \\
-- \\
--\end{array}$ & $\begin{array}{l}-- \\
-- \\
.42 \\
-- \\
-- \\
-- \\
.45 \\
--\end{array}$ & $\begin{array}{l}-- \\
-- \\
.72 \\
-- \\
-- \\
-- \\
-- \\
.70 \\
--\end{array}$ & $\begin{array}{l}-- \\
- \\
50 \\
- \\
-- \\
-- \\
-- \\
.50 \\
--\end{array}$ & $\begin{array}{r}-- \\
9.0 \\
-- \\
-- \\
-- \\
-- \\
8.6 \\
-- \\
--\end{array}$ \\
\hline $\begin{array}{l}02 \\
02 \\
02 \\
02\end{array}$ & $\begin{array}{l}0400 \\
0800 \\
1200 \\
1430\end{array}$ & $\begin{array}{r}1.19 \\
1.10 \\
1.02 \\
.99\end{array}$ & $\begin{array}{l}34 \\
34 \\
34 \\
33\end{array}$ & $\begin{array}{l}5.89 \\
5.91 \\
5.91 \\
5.96\end{array}$ & $\begin{array}{l}-- \\
-- \\
.017\end{array}$ & $\begin{array}{l}-- \\
-- \\
2.8\end{array}$ & $\begin{array}{l}-- \\
-- \\
-\overline{.98}\end{array}$ & $\begin{array}{l}-. \\
\cdots \\
.- \\
.52\end{array}$ & $\begin{array}{l}\ldots \\
\cdots \\
.- \\
.79\end{array}$ & $\begin{array}{l}-- \\
\cdots \\
.5 \\
.50\end{array}$ & $\begin{array}{c}-- \\
-- \\
8.3\end{array}$ \\
\hline
\end{tabular}


Table 14.--Water-quality data for rainfall and snommelt runoff at South Fork Bens Creek near Thomasdale, 1983-86--Continued

$\left[\mathrm{m}^{3} / \mathrm{s}\right.$, cubic meters per second; $\mu \mathrm{S} / \mathrm{cm}$, microsiemens per centimeter at 25 degrees Celsius; mg/L, milligrams per liter; $\mu g / L$, micrograms per liter; <, less than; --, indicates no data ]

\begin{tabular}{|c|c|c|c|c|c|c|c|c|c|c|c|}
\hline Date & $\begin{array}{l}\text { Chlo- } \\
\text { ride, } \\
\text { dis- } \\
\text { solved } \\
(\mathrm{mg} / \mathrm{L})\end{array}$ & $\begin{array}{l}\text { Fluo- } \\
\text { ride, } \\
\text { dis- } \\
\text { solved } \\
\text { (mg/L) }\end{array}$ & $\begin{array}{l}\text { Bromide, } \\
\text { dis- } \\
\text { solved } \\
\text { (mg/L) }\end{array}$ & $\begin{array}{l}\text { Silica, } \\
\text { dis- } \\
\text { solved } \\
(\mathrm{mg} / \mathrm{L})\end{array}$ & $\begin{array}{l}\text { Nitro- } \\
\text { gen } \\
\text { ammonia, } \\
\text { dis- } \\
\text { solved } \\
\text { (mg/L } \\
\text { as } N \text { ) }\end{array}$ & $\begin{array}{l}\text { Fhos- } \\
\text { fhorus, } \\
\text { ortho, } \\
\text { dis- } \\
\text { solved } \\
\text { (ms/L) }\end{array}$ & $\begin{array}{l}\text { Alum- } \\
\text { Inum, } \\
\text { dis- } \\
\text { solved } \\
(\mu g / L)\end{array}$ & $\begin{array}{l}\text { Iron, } \\
\text { dis- } \\
\text { solved } \\
\left(\mu_{8} / L\right)\end{array}$ & $\begin{array}{l}\text { Manga- } \\
\text { nese, } \\
\text { dis- } \\
\text { solved } \\
(\mu g / L)\end{array}$ & $\begin{array}{l}\text { Carbon, } \\
\text { organic, } \\
\text { dis- } \\
\text { solved } \\
\text { (mg/L) }\end{array}$ & $\begin{array}{l}\text { Nitrogen } \\
\text { nitrate, } \\
\text { dissolved } \\
(\mathrm{mg} / \mathrm{L} \\
\text { as } \mathrm{N})\end{array}$ \\
\hline MAR & & & & & & 1985 & & & & & \\
\hline $\begin{array}{l}29 \\
29 \\
29 \\
29 \\
29 \\
29 \\
29 \\
29 \\
29 \\
29\end{array}$ & $\begin{array}{l}0.8 \\
-- \\
.86 \\
-- \\
.90 \\
-- \\
-- \\
.86 \\
-- \\
--\end{array}$ & $\begin{array}{c}0.07 \\
-- \\
.06 \\
-- \\
.06 \\
-- \\
-- \\
.07 \\
-- \\
--\end{array}$ & $\begin{array}{l}0.02 \\
-- \\
.03 \\
-- \\
.03 \\
-- \\
-- \\
.03 \\
-- \\
--\end{array}$ & $\begin{array}{r}3.0 \\
-- \\
3.2 \\
-- \\
3.5 \\
-- \\
-- \\
3.5 \\
-- \\
--\end{array}$ & $\begin{array}{l}0.011 \\
=- \\
.006 \\
-- \\
.005 \\
-- \\
-- \\
.005 \\
-- \\
--\end{array}$ & $\begin{array}{l}0.001 \\
-- \\
.001 \\
-- \\
.001 \\
-- \\
-- \\
.001 \\
-- \\
--\end{array}$ & $\begin{array}{l}30 \\
-- \\
40 \\
-- \\
50 \\
-- \\
-- \\
40 \\
-- \\
--\end{array}$ & $\begin{array}{r}5 \\
-- \\
-5 \\
-5 \\
-- \\
-- \\
4 \\
--\end{array}$ & $\begin{array}{l}17 \\
-- \\
31 \\
-- \\
37 \\
-- \\
-- \\
28 \\
-- \\
--\end{array}$ & $\begin{array}{c}0.70 \\
-- \\
1.2 \\
-- \\
1.0 \\
-- \\
-- \\
.90 \\
-- \\
--\end{array}$ & $\begin{array}{c}0.78 \\
-- \\
.82 \\
-- \\
.88 \\
-- \\
-- \\
.83 \\
-- \\
--\end{array}$ \\
\hline $\begin{array}{l}30 \\
30\end{array}$ & .84 & .05 & .03 & 3.2 & .010 & .002 & 50 & -- & $\overline{37}$ & .80 & .85 \\
\hline $\begin{array}{l}31 \\
31 \\
31 \\
31 \\
31 \\
31 \\
31 \\
31 \\
31\end{array}$ & $\begin{array}{l}.84 \\
.83 \\
-- \\
.83 \\
-- \\
-- \\
-- \\
-- \\
.84\end{array}$ & $\begin{array}{l}.05 \\
.05 \\
-- \\
.05 \\
-- \\
-- \\
-- \\
-- \\
.05\end{array}$ & $\begin{array}{l}.02 \\
.02 \\
-- \\
.02 \\
-- \\
-- \\
-- \\
-- \\
.02\end{array}$ & $\begin{array}{r}3.4 \\
2.9 \\
-- \\
3.2 \\
-- \\
-- \\
-- \\
-- \\
3.4\end{array}$ & $\begin{array}{l}.014 \\
.029 \\
- \\
.034 \\
-- \\
-- \\
-- \\
.008\end{array}$ & $\begin{array}{l}.001 \\
.001 \\
-- \\
.001 \\
-- \\
-- \\
-- \\
-- \\
.001\end{array}$ & $\begin{array}{l}70 \\
70 \\
-- \\
90 \\
-- \\
-- \\
-- \\
-- \\
80\end{array}$ & $\begin{array}{r}5 \\
5 \\
-- \\
5 \\
-- \\
-- \\
-- \\
-- \\
4\end{array}$ & $\begin{array}{l}42 \\
50 \\
-- \\
55 \\
-- \\
-- \\
-- \\
-- \\
50\end{array}$ & $\begin{array}{l}-- \\
-- \\
-- \\
-- \\
-- \\
-- \\
-- \\
--\end{array}$ & $\begin{array}{l}.86 \\
.88 \\
-- \\
.88 \\
-- \\
-- \\
-- \\
-- \\
.91\end{array}$ \\
\hline \multicolumn{12}{|l|}{ APR } \\
\hline $\begin{array}{l}01 \\
01 \\
01 \\
01 \\
01 \\
01 \\
01 \\
01 \\
01 \\
01\end{array}$ & $\begin{array}{l}-8 \\
.84 \\
-- \\
-- \\
-- \\
.89 \\
-- \\
-- \\
--\end{array}$ & $\begin{array}{l}-- \\
.06 \\
-- \\
-- \\
-- \\
-- \\
.05 \\
-- \\
--\end{array}$ & $\begin{array}{l}-- \\
.03 \\
-- \\
-- \\
-- \\
-- \\
.03 \\
-- \\
-- \\
--\end{array}$ & $\begin{array}{l}3.4 \\
-- \\
-- \\
-- \\
-- \\
3.4 \\
-- \\
-- \\
--\end{array}$ & $\begin{array}{l}-- \\
.010 \\
-- \\
-- \\
-- \\
-- \\
.009 \\
-- \\
-- \\
--\end{array}$ & $\begin{array}{l}-- \\
.001 \\
-- \\
-- \\
-- \\
-- \\
.001 \\
-- \\
-- \\
--\end{array}$ & $\begin{array}{l}-- \\
70 \\
-- \\
-- \\
-- \\
-- \\
50 \\
-- \\
-- \\
--\end{array}$ & $\begin{array}{r}-- \\
4 \\
-- \\
-- \\
-- \\
-- \\
3 \\
-- \\
--\end{array}$ & $\begin{array}{l}-- \\
42 \\
-- \\
-- \\
-- \\
-- \\
32 \\
-- \\
-- \\
--\end{array}$ & $\begin{array}{l}-- \\
-- \\
-- \\
-- \\
-- \\
-- \\
-- \\
-- \\
--\end{array}$ & $\begin{array}{l}-- \\
.91 \\
-- \\
-- \\
-- \\
-- \\
.89 \\
-- \\
-- \\
--\end{array}$ \\
\hline $\begin{array}{l}02 \\
02 \\
02 \\
02\end{array}$ & $\begin{array}{l}-- \\
-- \\
-- \\
.84\end{array}$ & $\begin{array}{l}-- \\
-- \\
-- \\
.05\end{array}$ & $\begin{array}{l}-- \\
-- \\
-- \\
.03\end{array}$ & $\begin{array}{l}-- \\
-- \\
-\overline{7} \\
3.7\end{array}$ & $\begin{array}{l}-- \\
- \\
.008\end{array}$ & $\begin{array}{l}-- \\
-- \\
-- \\
.001\end{array}$ & $\overline{--}$ & $\begin{array}{c}-- \\
-- \\
-- \\
4\end{array}$ & $\begin{array}{l}-- \\
-- \\
-\overline{23}\end{array}$ & $\begin{array}{l}-- \\
-- \\
-- \\
--\end{array}$ & $\begin{array}{l}-- \\
-- \\
-- \\
.87\end{array}$ \\
\hline
\end{tabular}


Table 14.--Water-quality data for rainfall and snowmelt runoff at South Fork Bens Creok near Thomasdale, 1983-86--Continued

$\left[\mathrm{m}^{3} / \mathrm{s}\right.$, cubic meters per second; $\mu \mathrm{s} / \mathrm{cm}$, microsiemens per centimeter at 25 degrees Celsius; mg/L, milligrams per liter; $\mu \mathrm{g} / \mathrm{L}$, micrograms per liter; <, less than; --, indicates no data]

\begin{tabular}{|c|c|c|c|c|c|c|c|c|c|c|c|}
\hline & & & Spe- & & & & & & & Alka- & \\
\hline & & Stream- & cific & & & & Magne- & & Potas- & linity, & \\
\hline Date & Time & $\begin{array}{l}\text { flow, } \\
\text { instan- } \\
\text { taneous } \\
\left(\mathrm{m}^{3} / \mathrm{s}\right)\end{array}$ & $\begin{array}{l}\text { con- } \\
\text { duct- } \\
\text { ance } \\
(\mu \mathrm{S} / \mathrm{cm})\end{array}$ & $\begin{array}{l}\mathrm{pH} \\
\text { (stand- } \\
\text { ard } \\
\text { units) }\end{array}$ & $\begin{array}{l}\text { Acidity } \\
(\mathrm{mg} / \mathrm{L} \\
\left.\text { as } \mathrm{H}^{+}\right)\end{array}$ & $\begin{array}{l}\text { Calcium, } \\
\text { dis- } \\
\text { solved } \\
(\mathrm{mg} / \mathrm{L})\end{array}$ & $\begin{array}{l}\text { sium, } \\
\text { dis- } \\
\text { solved } \\
\text { (mg/L) }\end{array}$ & $\begin{array}{l}\text { Sodium, } \\
\text { dis- } \\
\text { solved } \\
(\mathrm{mg} / \mathrm{L})\end{array}$ & $\begin{array}{l}\text { sium, } \\
\text { dis- } \\
\text { solved } \\
\text { (mg/L) }\end{array}$ & $\begin{array}{l}1 \mathrm{ab} \\
(\mathrm{mg} / \mathrm{L} \\
\mathrm{as} \\
\left.\mathrm{CaCO}_{3}\right)\end{array}$ & $\begin{array}{l}\text { Sulfate, } \\
\text { dis- } \\
\text { solved } \\
\text { (mg/L) }\end{array}$ \\
\hline
\end{tabular}

MAY

\begin{tabular}{|c|c|c|c|c|c|c|c|c|c|c|c|}
\hline $\begin{array}{l}02 \\
02 \\
02 \\
02 \\
02 \\
02 \\
02 \\
02\end{array}$ & $\begin{array}{l}1445 \\
1545 \\
1645 \\
1745 \\
1845 \\
2045 \\
2245 \\
0045\end{array}$ & $\begin{array}{l}0.17 \\
.20 \\
.27 \\
.37 \\
.57 \\
.57 \\
.68 \\
.99\end{array}$ & $\begin{array}{l}38 \\
36 \\
37 \\
36 \\
37 \\
38 \\
38 \\
38\end{array}$ & $\begin{array}{l}6.53 \\
6.50 \\
6.49 \\
6.40 \\
6.33 \\
6.30 \\
6.22 \\
6.08\end{array}$ & $\begin{array}{l}0.037 \\
-- \\
-- \\
.044 \\
-\overline{0} \\
.043 \\
-- \\
--\end{array}$ & $\begin{array}{r}2.6 \\
-- \\
2.5 \\
-- \\
3.5 \\
--\end{array}$ & $\begin{array}{c}0.80 \\
-- \\
-- \\
.80 \\
-- \\
1.1 \\
-- \\
--\end{array}$ & $\begin{array}{l}0.40 \\
-- \\
-- \\
.40 \\
- \\
.50 \\
-- \\
--\end{array}$ & $\begin{array}{c}0.62 \\
-- \\
-- \\
.76 \\
-- \\
.52 \\
-- \\
--\end{array}$ & $\begin{array}{l}2.5 \\
-- \\
-- \\
.50 \\
-- \\
.50 \\
-- \\
--\end{array}$ & $\begin{array}{r}8.3 \\
-- \\
-- \\
8.9 \\
-- \\
9.4 \\
-- \\
--\end{array}$ \\
\hline $\begin{array}{l}03 \\
03 \\
03 \\
03\end{array}$ & $\begin{array}{l}0245 \\
0645 \\
1045 \\
1445\end{array}$ & $\begin{array}{l}.93 \\
.85 \\
.76 \\
.79\end{array}$ & $\begin{array}{l}38 \\
39 \\
38 \\
38\end{array}$ & $\begin{array}{l}6.03 \\
6.08 \\
6.19 \\
6.32\end{array}$ & $\begin{array}{c}.047 \\
=- \\
=-\end{array}$ & $\begin{array}{r}3.6 \\
=- \\
--\end{array}$ & $\begin{array}{c}1.1 \\
=- \\
--\end{array}$ & $\begin{array}{l}.40 \\
-- \\
-- \\
--\end{array}$ & $\begin{array}{l}.48 \\
=- \\
-- \\
--\end{array}$ & $\begin{array}{l}.50 \\
-- \\
-- \\
--\end{array}$ & 10 \\
\hline
\end{tabular}

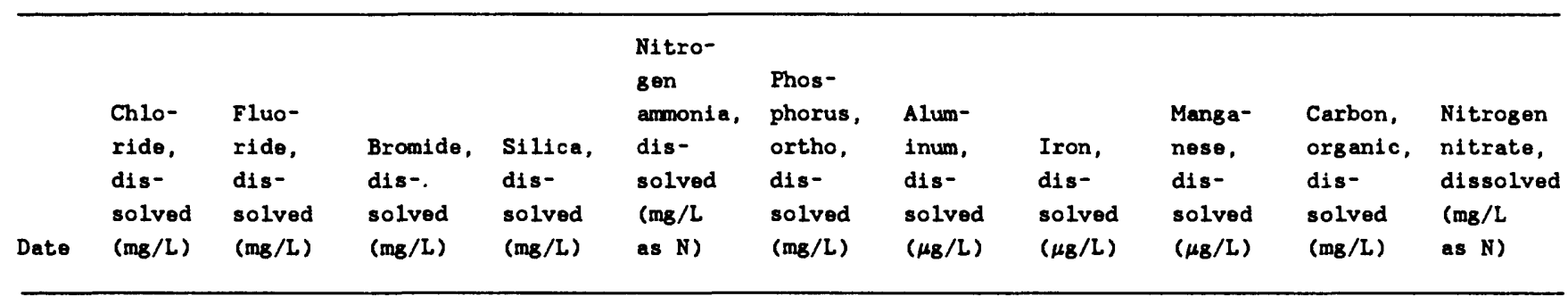

MAY

\begin{tabular}{|c|c|c|c|c|c|c|c|c|c|c|c|}
\hline $\begin{array}{l}02 \\
02 \\
02 \\
02 \\
02 \\
02 \\
02 \\
02\end{array}$ & $\begin{array}{l}0.86 \\
-- \\
-- \\
.86 \\
-- \\
.85 \\
-- \\
--\end{array}$ & $\begin{array}{l}0.05 \\
-- \\
-- \\
.05 \\
-- \\
.06 \\
-- \\
--\end{array}$ & $\begin{array}{l}0.02 \\
-- \\
-- \\
.02 \\
-- \\
.02 \\
--\end{array}$ & $\begin{array}{r}2.9 \\
-- \\
-- \\
2.7 \\
=- \\
3.9 \\
-= \\
=-\end{array}$ & $\begin{array}{l}0.015 \\
-- \\
-- \\
.014 \\
-- \\
.026 \\
-- \\
--\end{array}$ & $\begin{array}{c}0.002 \\
-- \\
-- \\
.010 \\
-- \\
.006 \\
-- \\
=-\end{array}$ & $\begin{array}{l}30 \\
-- \\
-- \\
50 \\
-- \\
50 \\
-- \\
--\end{array}$ & $\begin{array}{r}5 \\
-- \\
-- \\
-- \\
6 \\
--\end{array}$ & $\begin{array}{l}28 \\
-- \\
-- \\
31 \\
-- \\
53 \\
-- \\
--\end{array}$ & $\begin{array}{r}3.0 \\
-- \\
-- \\
2.6 \\
-\overline{2} \\
2.6 \\
--\end{array}$ & $\begin{array}{c}0.68 \\
-- \\
-- \\
.70 \\
-- \\
.76 \\
-- \\
--\end{array}$ \\
\hline $\begin{array}{l}03 \\
03 \\
03 \\
03\end{array}$ & $\begin{array}{l}.87 \\
-- \\
-- \\
--\end{array}$ & $\begin{array}{l}.06 \\
-- \\
-- \\
--\end{array}$ & $\begin{array}{l}.02 \\
-- \\
-- \\
--\end{array}$ & $\begin{array}{c}3.7 \\
-- \\
-- \\
--\end{array}$ & $\begin{array}{l}.015 \\
=- \\
-- \\
--\end{array}$ & $\begin{array}{c}.003 \\
-- \\
-- \\
--\end{array}$ & $\begin{array}{l}90 \\
-- \\
-- \\
--\end{array}$ & $\begin{array}{c}6 \\
-- \\
--\end{array}$ & $\begin{array}{l}72 \\
-- \\
-- \\
--\end{array}$ & $\begin{array}{l}-- \\
-- \\
-- \\
--\end{array}$ & $\begin{array}{l}.84 \\
-- \\
-- \\
--\end{array}$ \\
\hline
\end{tabular}


Table 14.--Water-quality data for rainfall and snownelt runoff at South Fork Bens Creek near Thomasdale, 1983-86--Continued

$\left[\mathrm{m}^{3} / \mathrm{s}\right.$, cubic meters per second; $\mu \mathrm{S} / \mathrm{cm}$, microsiemens per centimeter at 25 degrees Celsius; mg/L, milligtams per liter; $\mu \mathrm{g} / \mathrm{L}$, micrograms per liter; <, less than; --, indicates no data]

\begin{tabular}{|c|c|c|c|c|c|c|c|c|c|c|c|}
\hline Date & Time & $\begin{array}{l}\text { Stream- } \\
\text { flow, } \\
\text { instan- } \\
\text { taneous } \\
\left(\mathrm{m}^{3} / \mathrm{s}\right)\end{array}$ & $\begin{array}{l}\text { Spe- } \\
\text { cific } \\
\text { con- } \\
\text { duct- } \\
\text { ance } \\
(\mu S / c m)\end{array}$ & $\begin{array}{l}\mathrm{pH} \\
\text { (stand- } \\
\text { ard } \\
\text { units) }\end{array}$ & $\begin{array}{l}\text { Acidity } \\
\text { (mg/L } \\
\text { as } \mathbf{B}^{+} \text {) }\end{array}$ & $\begin{array}{l}\text { Calcium, } \\
\text { dis- } \\
\text { solved } \\
(\mathrm{mg} / \mathrm{L})\end{array}$ & $\begin{array}{l}\text { Magne- } \\
\text { sium, } \\
\text { dis- } \\
\text { solved } \\
(\mathrm{mg} / \mathrm{L})\end{array}$ & $\begin{array}{l}\text { Sodium, } \\
\text { dis- } \\
\text { solved } \\
(\mathrm{mg} / \mathrm{L})\end{array}$ & $\begin{array}{l}\text { Potas- } \\
\text { sium, } \\
\text { dis- } \\
\text { solved } \\
\text { (ms/L) }\end{array}$ & $\begin{array}{l}\text { Alka- } \\
\text { linity, } \\
\text { lab } \\
(\mathrm{mg} / \mathrm{L} \\
\text { as } \\
\left.\mathrm{CaCO}_{3}\right)\end{array}$ & $\begin{array}{l}\text { Sulfate, } \\
\text { dis- } \\
\text { solved } \\
\text { (ms/L) }\end{array}$ \\
\hline JULY & \multicolumn{11}{|c|}{1985} \\
\hline $\begin{array}{l}21 \\
21 \\
21\end{array}$ & $\begin{array}{l}2145 \\
2245 \\
2345\end{array}$ & $\begin{array}{r}0.03 \\
.16 \\
.20\end{array}$ & $\begin{array}{l}40 \\
38 \\
37\end{array}$ & $\begin{array}{l}6.55 \\
6.48 \\
6.49\end{array}$ & $\begin{array}{r}-- \\
0.067 \\
.058\end{array}$ & $\begin{array}{l}3.9 \\
3.7 \\
3.5\end{array}$ & $\begin{array}{r}0.90 \\
.90 \\
.80\end{array}$ & $\begin{array}{r}0.80 \\
.60 \\
.80\end{array}$ & $\begin{array}{r}0.61 \\
.66 \\
.68\end{array}$ & $\begin{array}{l}5.6 \\
3.6 \\
2.9\end{array}$ & $\begin{array}{l}7.2 \\
7.6 \\
7.9\end{array}$ \\
\hline $\begin{array}{l}22 \\
22 \\
22 \\
22 \\
22 \\
22 \\
22 \\
22 \\
22\end{array}$ & $\begin{array}{l}0045 \\
0145 \\
0345 \\
0545 \\
0745 \\
0945 \\
1345 \\
1745 \\
2145\end{array}$ & $\begin{array}{l}.18 \\
.14 \\
.12 \\
.08 \\
.05 \\
.07 \\
.07 \\
.07 \\
.07\end{array}$ & $\begin{array}{l}38 \\
38 \\
39 \\
40 \\
39 \\
39 \\
38 \\
38 \\
40\end{array}$ & $\begin{array}{l}6.58 \\
6.68 \\
6.72 \\
6.82 \\
6.79 \\
6.81 \\
6.85 \\
6.64 \\
6.71\end{array}$ & $\begin{array}{l}.050 \\
-- \\
-- \\
=- \\
-- \\
.033 \\
=- \\
-- \\
.035\end{array}$ & $\begin{array}{r}3.4 \\
-.- \\
4.1 \\
-.- \\
4.1 \\
--- \\
-- \\
3.7\end{array}$ & $\begin{array}{c}.80 \\
-- \\
1.0 \\
--- \\
1.0 \\
-0 \\
.90\end{array}$ & $\begin{array}{l}.60 \\
-- \\
.70 \\
-- \\
-- \\
.70 \\
-- \\
-- \\
.60\end{array}$ & $\begin{array}{l}.58 \\
-- \\
.66 \\
-- \\
-- \\
.66 \\
-- \\
-- \\
.50\end{array}$ & $\begin{array}{r}3.3 \\
-- \\
4.8 \\
-- \\
-- \\
4.8 \\
-- \\
-- \\
4.0\end{array}$ & $\begin{array}{r}8.1 \\
--- \\
7.5 \\
--- \\
7.5 \\
--5 \\
-- \\
8.1\end{array}$ \\
\hline Date & $\begin{array}{l}\text { Chlo- } \\
\text { ride, } \\
\text { dis- } \\
\text { solved } \\
\text { (mg/L) }\end{array}$ & $\begin{array}{l}\text { Fluo- } \\
\text { ride, } \\
\text { dis- } \\
\text { solved } \\
\text { (mg/L) }\end{array}$ & $\begin{array}{l}\text { Bromide, } \\
\text { dis- } \\
\text { solved } \\
\text { (mg/L) }\end{array}$ & $\begin{array}{l}\text { Silica, } \\
\text { dis- } \\
\text { solved } \\
(\mathrm{mg} / \mathrm{L})\end{array}$ & $\begin{array}{l}\text { Nitro- } \\
\text { gen } \\
\text { ammonia, } \\
\text { dis- } \\
\text { solved } \\
\text { (mg/L } \\
\text { as } N \text { ) }\end{array}$ & $\begin{array}{l}\text { Phos- } \\
\text { phorus, } \\
\text { ortho, } \\
\text { dis- } \\
\text { solved } \\
\text { (mg/L) }\end{array}$ & $\begin{array}{l}\text { Alum- } \\
\text { inum, } \\
\text { dis- } \\
\text { solved } \\
\left(\mu_{8} / L\right)\end{array}$ & $\begin{array}{l}\text { Iron, } \\
\text { dis- } \\
\text { solved } \\
(\mu g / L)\end{array}$ & $\begin{array}{l}\text { Manga- } \\
\text { nese, } \\
\text { dis- } \\
\text { solved } \\
(\mu g / L)\end{array}$ & $\begin{array}{l}\text { Carbon, } \\
\text { organic, } \\
\text { dis- } \\
\text { solved } \\
\text { (mg/L) }\end{array}$ & $\begin{array}{l}\text { Nitrogen } \\
\text { nitrate, } \\
\text { dissolved } \\
(\mathrm{mg} / \mathrm{L} \\
\text { as } N \text { ) }\end{array}$ \\
\hline \multicolumn{12}{|l|}{ JULY } \\
\hline $\begin{array}{l}21 \\
21 \\
21\end{array}$ & $\begin{array}{r}0.89 \\
.80 \\
.76\end{array}$ & $\begin{array}{l}0.06 \\
.06 \\
.08\end{array}$ & $\begin{array}{r}0.03 \\
.02 \\
.02\end{array}$ & $\begin{array}{l}3.3 \\
2.7 \\
2.9\end{array}$ & $\begin{array}{r}0.036 \\
.024 \\
.014\end{array}$ & $\begin{array}{r}<0.001 \\
<.001 \\
4.001\end{array}$ & $\begin{array}{l}20 \\
20 \\
46\end{array}$ & $\begin{array}{r}9 \\
16 \\
31\end{array}$ & $\begin{array}{r}8 \\
28 \\
72\end{array}$ & $\begin{array}{l}2.2 \\
3.6 \\
3.6\end{array}$ & $\begin{array}{r}0.70 \\
.64 \\
.57\end{array}$ \\
\hline $\begin{array}{l}22 \\
22 \\
22 \\
22 \\
22 \\
22 \\
22 \\
22 \\
22\end{array}$ & $\begin{array}{l}.78 \\
-- \\
-- \\
-- \\
-- \\
.84 \\
-- \\
-- \\
.82\end{array}$ & $\begin{array}{l}.08 \\
-- \\
=- \\
=- \\
-- \\
.06 \\
=- \\
-- \\
.07\end{array}$ & $\begin{array}{l}.02 \\
-- \\
-- \\
-- \\
-- \\
.03 \\
-- \\
-- \\
.02\end{array}$ & $\begin{array}{r}3.0 \\
-- \\
-- \\
-- \\
-- \\
4.1 \\
-- \\
-- \\
3.7\end{array}$ & $\begin{array}{l}.013 \\
=- \\
-- \\
-- \\
-- \\
.014 \\
-- \\
-- \\
.022\end{array}$ & $\begin{array}{l}<.001 \\
-- \\
-- \\
-- \\
-- \\
.001 \\
-- \\
-0 \\
.001\end{array}$ & $\begin{array}{l}16 \\
-- \\
-- \\
-- \\
-- \\
10 \\
-- \\
-- \\
17\end{array}$ & $\begin{array}{c}9 \\
-- \\
-- \\
-- \\
-\overline{9} \\
9.4 \\
-- \\
9.4\end{array}$ & 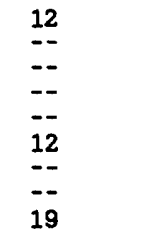 & $\begin{array}{r}3.1 \\
-- \\
-- \\
-- \\
-- \\
2.4 \\
-- \\
-\overline{3}\end{array}$ & $\begin{array}{l}.56 \\
-- \\
-- \\
-- \\
-- \\
.62 \\
-- \\
-- \\
.58\end{array}$ \\
\hline
\end{tabular}


Table 15.--Water-quality data for rainfall and snowmelt runoff at North Fork Bens Creek at North Fork Reservoir, 1984-86

$\left[\mathrm{m}^{3} / \mathrm{s}\right.$, cubic meters per second; $\mu \mathrm{S} / \mathrm{cm}$, microsiemens per centimeter at 25 degrees Celsius; mg/L, milligrams per liter; $\mu 8 / \mathrm{L}$, micrograms per liter: <, less than; --, indicates no data]

\begin{tabular}{|c|c|c|c|c|c|c|c|c|c|c|c|}
\hline Date & Time & $\begin{array}{l}\text { Stream- } \\
\text { flow, } \\
\text { instan- } \\
\text { taneous } \\
\left(\mathrm{m}^{3} / \mathrm{s}\right)\end{array}$ & $\begin{array}{l}\text { Spe- } \\
\text { cif1c } \\
\text { con- } \\
\text { duct- } \\
\text { ance } \\
(\mu S / \mathrm{cm})\end{array}$ & $\begin{array}{l}\text { pH } \\
\text { (stand- } \\
\text { ard } \\
\text { units) }\end{array}$ & $\begin{array}{l}\text { Acidity } \\
(\mathrm{mg} / \mathrm{L} \\
\left.\text { as } \mathrm{H}^{+}\right)\end{array}$ & $\begin{array}{l}\text { Calcium, } \\
\text { dis- } \\
\text { solved } \\
\text { (mg/L) }\end{array}$ & $\begin{array}{l}\text { Magne- } \\
\text { sium, } \\
\text { dis- } \\
\text { solved } \\
\text { (mg/L) }\end{array}$ & $\begin{array}{l}\text { Sodium, } \\
\text { dis- } \\
\text { solved } \\
\text { (mg/L) }\end{array}$ & $\begin{array}{l}\text { Potas- } \\
\text { sium, } \\
\text { dis- } \\
\text { solved } \\
\text { (mg/L) }\end{array}$ & $\begin{array}{l}\text { Alka- } \\
\text { linity, } \\
\text { lab } \\
(\mathrm{mg} / \mathrm{L} \\
\mathrm{as} \\
\mathrm{CaCO}_{3} \text { ) }\end{array}$ & $\begin{array}{l}\text { Sulfate, } \\
\text { dis- } \\
\text { solved } \\
(\mathrm{mg} / \mathrm{L})\end{array}$ \\
\hline & & & & & & 984 & & & & & \\
\hline $\begin{array}{r}\text { DEC } \\
19 \\
19 \\
19 \\
19 \\
19 \\
19 \\
19 \\
19 \\
19 \\
19 \\
19 \\
19\end{array}$ & $\begin{array}{l}0300 \\
0400 \\
0500 \\
0600 \\
0700 \\
0800 \\
1000 \\
1200 \\
1400 \\
1600 \\
2000 \\
2400\end{array}$ & $\begin{array}{l}0.28 \\
.28 \\
.28 \\
.31 \\
.31 \\
.36 \\
.45 \\
.48 \\
.56 \\
.54 \\
.45 \\
.42\end{array}$ & $\begin{array}{l}45 \\
44 \\
44 \\
44 \\
44 \\
45 \\
44 \\
43 \\
43 \\
43 \\
42 \\
44\end{array}$ & $\begin{array}{l}5.62 \\
5.78 \\
5.81 \\
5.81 \\
5.81 \\
5.85 \\
5.80 \\
5.61 \\
5.49 \\
5.49 \\
5.50 \\
5.60\end{array}$ & $\begin{array}{l}0.10 \\
-- \\
-- \\
-- \\
-- \\
-- \\
- \\
.10 \\
-- \\
.10 \\
--\end{array}$ & $\begin{array}{r}3.6 \\
-- \\
-- \\
-- \\
-- \\
-- \\
-- \\
3.6 \\
-- \\
3.7 \\
-- \\
--\end{array}$ & $\begin{array}{c}1.0 \\
-- \\
-- \\
-- \\
- \\
1.0 \\
-\overline{-} \\
1.1 \\
-- \\
--\end{array}$ & $\begin{array}{l}1.5 \\
-- \\
-- \\
-- \\
-- \\
-- \\
-- \\
1.1 \\
-- \\
1.2 \\
-- \\
--\end{array}$ & $\begin{array}{l}0.68 \\
-- \\
-- \\
-- \\
-- \\
-- \\
-- \\
.86 \\
-- \\
.68 \\
-- \\
--\end{array}$ & $\begin{array}{c}1.0 \\
-- \\
-- \\
-- \\
-- \\
-- \\
-- \\
1.0 \\
-0 \\
1.0 \\
-- \\
--\end{array}$ & $\begin{array}{l}11 \\
-- \\
-- \\
-- \\
-- \\
-- \\
11 \\
-- \\
11 \\
-- \\
--\end{array}$ \\
\hline $\begin{array}{l}20 \\
20 \\
20 \\
20 \\
20 \\
20 \\
20 \\
20 \\
20\end{array}$ & $\begin{array}{l}1115 \\
1215 \\
1315 \\
1415 \\
1515 \\
1615 \\
1815 \\
2015 \\
2215\end{array}$ & $\begin{array}{l}.34 \\
.34 \\
.34 \\
.34 \\
.34 \\
.34 \\
.34 \\
.34 \\
.34\end{array}$ & $\begin{array}{l}42 \\
42 \\
42 \\
43 \\
42 \\
42 \\
40 \\
41 \\
41\end{array}$ & $\begin{array}{l}5.55 \\
5.60 \\
5.61 \\
5.60 \\
5.62 \\
5.63 \\
5.67 \\
5.70 \\
5.70\end{array}$ & $\begin{array}{l}.10 \\
-- \\
- \\
.10 \\
-- \\
-- \\
-- \\
--\end{array}$ & $\begin{array}{c}3.7 \\
-- \\
-- \\
3.6 \\
-- \\
-- \\
-- \\
-- \\
--\end{array}$ & $\begin{array}{c}1.1 \\
-- \\
-- \\
1.0 \\
-- \\
-- \\
-- \\
--\end{array}$ & $\begin{array}{c}1.4 \\
-- \\
-- \\
1.3 \\
-- \\
-- \\
-- \\
-- \\
--\end{array}$ & $\begin{array}{l}.62 \\
-- \\
-- \\
.62 \\
-- \\
-- \\
-- \\
-- \\
--\end{array}$ & $\begin{array}{c}1.0 \\
-- \\
-- \\
1.0 \\
-- \\
-- \\
-- \\
--\end{array}$ & $\begin{array}{l}11 \\
-- \\
-- \\
10 \\
-- \\
-- \\
-- \\
--\end{array}$ \\
\hline $\begin{array}{l}21 \\
21 \\
21 \\
\end{array}$ & $\begin{array}{l}0215 \\
0615 \\
1015 \\
\end{array}$ & $\begin{array}{l}.31 \\
.31 \\
.34 \\
\end{array}$ & $\begin{array}{l}40 \\
39 \\
39 \\
\end{array}$ & $\begin{array}{l}5.67 \\
5.67 \\
5.67 \\
\end{array}$ & $\begin{array}{l}.10 \\
-2 \\
.10\end{array}$ & $\begin{array}{r}3.6 \\
-- \\
3.5 \\
\end{array}$ & $\begin{array}{r}1.1 \\
-2 \\
1.1 \\
\end{array}$ & $\begin{array}{r}1.3 \\
-0 \\
1.3 \\
\end{array}$ & $\begin{array}{c}.62 \\
-- \\
.62 \\
\end{array}$ & $\begin{array}{r}1.0 \\
-0 \\
1.0 \\
\end{array}$ & $\begin{array}{l}10 \\
\frac{10}{10} \\
\end{array}$ \\
\hline Date & $\begin{array}{l}\text { Chlo- } \\
\text { ride, } \\
\text { dis- } \\
\text { solved } \\
\text { (mg/L) }\end{array}$ & $\begin{array}{l}\text { Fluo- } \\
\text { ride, } \\
\text { dis- } \\
\text { solved } \\
\text { (mg/L) }\end{array}$ & $\begin{array}{l}\text { Bromide, } \\
\text { dis- } \\
\text { solved } \\
\text { (mg/L) }\end{array}$ & $\begin{array}{l}\text { Silica, } \\
\text { dis- } \\
\text { solved } \\
\text { (mg/L) }\end{array}$ & $\begin{array}{l}\text { Nitro- } \\
\text { gen } \\
\text { ammonia, } \\
\text { dis- } \\
\text { solved } \\
\text { (mg/L } \\
\text { as } N \text { ) }\end{array}$ & $\begin{array}{l}\text { Phos- } \\
\text { phorus, } \\
\text { ortho, } \\
\text { dis- } \\
\text { solved } \\
\text { (mg/L) }\end{array}$ & $\begin{array}{l}\text { Alum- } \\
\text { inum, } \\
\text { dis- } \\
\text { solved } \\
(\mu 8 / L)\end{array}$ & $\begin{array}{l}\text { Iron, } \\
\text { dis- } \\
\text { solved } \\
(\mu g / L)\end{array}$ & $\begin{array}{l}\text { Manga- } \\
\text { nese, } \\
\text { dis- } \\
\text { solved } \\
\left(\mu_{B} / L\right)\end{array}$ & $\begin{array}{l}\text { Carbon, } \\
\text { organic, } \\
\text { dis- } \\
\text { solved } \\
\text { (mg/L) }\end{array}$ & $\begin{array}{l}\text { Nitrogen } \\
\text { nitrate, } \\
\text { dissolved } \\
(\mathrm{mg} / \mathrm{L} \\
\text { as } N \text { ) }\end{array}$ \\
\hline \multicolumn{12}{|l|}{ DEC } \\
\hline $\begin{array}{l}19 \\
19 \\
19 \\
19 \\
19 \\
19 \\
19 \\
19 \\
19 \\
19 \\
19 \\
19\end{array}$ & $\begin{array}{c}2.9 \\
-- \\
-- \\
-- \\
-- \\
-- \\
-- \\
2.1 \\
-\overline{1} \\
2.3 \\
-- \\
--\end{array}$ & $\begin{array}{l}0.07 \\
-- \\
-- \\
-- \\
-- \\
-- \\
-- \\
.06 \\
-- \\
.06 \\
-- \\
--\end{array}$ & 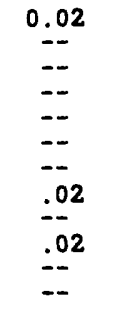 & $\begin{array}{c}4.1 \\
-- \\
-- \\
-- \\
-- \\
-- \\
-- \\
3.9 \\
4.0 \\
-- \\
--\end{array}$ & $\begin{array}{l}0.005 \\
-- \\
-- \\
-- \\
-- \\
-- \\
-- \\
.005 \\
-- \\
.005 \\
-- \\
--\end{array}$ & $\begin{array}{c}0.01 \\
-- \\
-- \\
=- \\
=- \\
=- \\
.01 \\
.002 \\
-- \\
--\end{array}$ & $\begin{array}{c}50 \\
-- \\
-- \\
-- \\
-- \\
\overline{-} \\
110 \\
110 \\
-- \\
--\end{array}$ & $\begin{array}{r}5 \\
-- \\
-- \\
-- \\
-- \\
-- \\
-- \\
8 \\
-- \\
4 \\
-- \\
--\end{array}$ & $\begin{array}{l}21 \\
-- \\
-- \\
-- \\
-- \\
-- \\
-- \\
53 \\
-- \\
50 \\
-- \\
--\end{array}$ & $\begin{array}{l}-- \\
-- \\
-- \\
-- \\
-- \\
-- \\
-- \\
2.2 \\
-- \\
-- \\
-- \\
--\end{array}$ & $\begin{array}{c}0.68 \\
-- \\
-- \\
-- \\
-- \\
-- \\
-- \\
.54 \\
-- \\
.57 \\
-- \\
--\end{array}$ \\
\hline $\begin{array}{l}20 \\
20 \\
20 \\
20 \\
20 \\
20 \\
20 \\
20 \\
20\end{array}$ & $\begin{array}{c}2.4 \\
-- \\
-- \\
2.4 \\
-- \\
-- \\
-- \\
--\end{array}$ & $\begin{array}{l}.07 \\
-- \\
-0 \\
.07 \\
-- \\
-- \\
--\end{array}$ & $\begin{array}{l}.02 \\
-- \\
-0 \\
.02 \\
-- \\
-- \\
-- \\
--\end{array}$ & $\begin{array}{c}4.2 \\
--- \\
-- \\
4.1 \\
-- \\
-- \\
-- \\
-- \\
--\end{array}$ & $\begin{array}{l}.005 \\
=- \\
-- \\
.005 \\
-- \\
-- \\
-- \\
-- \\
--\end{array}$ & $\begin{array}{c}.01 \\
-0 \\
.01 \\
- \\
- \\
- \\
-- \\
--\end{array}$ & $\begin{array}{l}80 \\
-- \\
-- \\
70 \\
-- \\
-- \\
-- \\
--\end{array}$ & $\begin{array}{r}5 \\
-- \\
-- \\
4 \\
-- \\
-- \\
-- \\
--\end{array}$ & $\begin{array}{l}30 \\
-- \\
-- \\
35 \\
-- \\
-- \\
-- \\
-- \\
--\end{array}$ & $\begin{array}{c}1.4 \\
-- \\
-- \\
1.0 \\
-- \\
-- \\
-- \\
-- \\
--\end{array}$ & $\begin{array}{l}.62 \\
-- \\
-- \\
.60 \\
-- \\
-- \\
-- \\
--\end{array}$ \\
\hline $\begin{array}{l}21 \\
21 \\
21 \\
\end{array}$ & $\begin{array}{r}2.4 \\
-4.4 \\
\end{array}$ & $\begin{array}{l}.07 \\
-.07 \\
\end{array}$ & $\begin{array}{c}.02 \\
-.02 \\
\end{array}$ & $\begin{array}{r}4.2 \\
-2.2 \\
4.2\end{array}$ & $\begin{array}{l}.005 \\
.006\end{array}$ & $\frac{.01}{.01}$ & $\begin{array}{l}70 \\
80 \\
80\end{array}$ & $\begin{array}{r}4 \\
-8 \\
\end{array}$ & $\begin{array}{l}33 \\
-33\end{array}$ & $\begin{array}{l}.80 \\
-.90 \\
.90\end{array}$ & $\begin{array}{l}.63 \\
-.64\end{array}$ \\
\hline
\end{tabular}


Table 15.--Water-quality data for rainfall and snowndt runoff at North Fork Bens Creek at North Fork Reservoir, 1984-86-Continued

$\left[\mathrm{m}^{3} / \mathrm{s}\right.$, cubic meters per second; $\mu \mathrm{s} / \mathrm{cm}$, microsiemens per centimeter at 25 degrees Celsius; mg/L, milligrams per fiter; $\mu \mathrm{g} / \mathrm{L}$, micrograms per liter; <, less than; --, indicates no dat ]

\begin{tabular}{|c|c|c|c|c|c|c|c|c|c|c|c|}
\hline Date & Time & $\begin{array}{l}\text { Stream- } \\
\text { flow, } \\
\text { instan- } \\
\text { taneous } \\
\left(m^{3} / s\right)\end{array}$ & $\begin{array}{l}\text { Spe- } \\
\text { cific } \\
\text { con- } \\
\text { duct- } \\
\text { ance } \\
(\mu \mathrm{S} / \mathrm{cm})\end{array}$ & $\begin{array}{l}\mathrm{pH} \\
\text { (stand- } \\
\text { ard } \\
\text { units) }\end{array}$ & $\begin{array}{l}\text { Acidity } \\
\text { (mg/L } \\
\left.\text { as } \mathrm{B}^{+}\right)\end{array}$ & $\begin{array}{l}\text { Calcium, } \\
\text { dis- } \\
\text { polved } \\
\text { (mg/L) }\end{array}$ & $\begin{array}{l}\text { Magne- } \\
\text { sium, } \\
\text { dis- } \\
\text { solved } \\
\text { (mg/L) }\end{array}$ & $\begin{array}{l}\text { Sodium, } \\
\text { dis- } \\
\text { solved } \\
\text { (mg/L) }\end{array}$ & $\begin{array}{l}\text { Potas- } \\
\text { sium, } \\
\text { dis- } \\
\text { solved } \\
\text { (mg/L) }\end{array}$ & $\begin{array}{l}\text { Alka- } \\
\text { linity, } \\
\text { lab } \\
(\mathrm{mg} / \mathrm{L} \\
\text { as } \\
\left.\mathrm{CaCO}_{3}\right)\end{array}$ & $\begin{array}{l}\text { Sulfate, } \\
\text { dis- } \\
\text { solved } \\
(\mathrm{mg} / \mathrm{L})\end{array}$ \\
\hline $\begin{array}{r}\text { DEC } \\
21 \\
21 \\
21 \\
21 \\
21 \\
21 \\
21 \\
21 \\
21 \\
21 \\
21 \\
21\end{array}$ & $\begin{array}{l}1030 \\
1130 \\
1230 \\
1330 \\
1430 \\
1530 \\
1630 \\
1730 \\
1830 \\
1930 \\
2030 \\
2230\end{array}$ & $\begin{array}{l}.34 \\
.34 \\
.34 \\
.36 \\
.48 \\
.51 \\
.54 \\
.54 \\
.54 \\
.56 \\
.62 \\
.65\end{array}$ & $\begin{array}{l}41 \\
42 \\
40 \\
39 \\
39 \\
39 \\
39 \\
40 \\
40 \\
40 \\
41 \\
40\end{array}$ & $\begin{array}{l}5.55 \\
5.70 \\
5.65 \\
5.69 \\
5.61 \\
5.45 \\
5.51 \\
5.52 \\
5.42 \\
5.45 \\
5.39 \\
5.36\end{array}$ & $\begin{array}{l}-- \\
-- \\
0.1 \\
-1 \\
.1 \\
.1 \\
-2 \\
-- \\
.1 \\
-2 \\
.1 \\
.1\end{array}$ & $\begin{array}{r}84 \\
-- \\
-. \\
3.6 \\
--6 \\
3.6 \\
3.6 \\
-- \\
3.6 \\
-- \\
3.6 \\
3.7\end{array}$ & 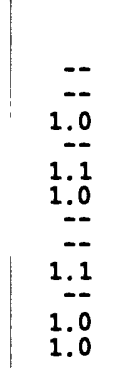 & $\begin{array}{r}-. \\
1.3 \\
-. \\
1.4 \\
1.2 \\
-2 \\
-- \\
1.2 \\
-2 \\
1.2 \\
1.2\end{array}$ & $\begin{array}{l}-. \\
-- \\
0.66 \\
-- \\
.70 \\
.72 \\
-. \\
.84 \\
.- \\
.79 \\
.76\end{array}$ & $\begin{array}{r}-- \\
1.0 \\
-- \\
1.0 \\
1.0 \\
-- \\
-- \\
1.0 \\
-- \\
1.0 \\
1.0\end{array}$ & $\begin{array}{l}-- \\
-\overline{10} \\
-\overline{10} \\
10 \\
10 \\
-- \\
-- \\
10 \\
-- \\
11 \\
11\end{array}$ \\
\hline $\begin{array}{l}22 \\
22 \\
22 \\
22 \\
22 \\
22 \\
22 \\
22\end{array}$ & $\begin{array}{l}2430 \\
0230 \\
0430 \\
0630 \\
1030 \\
1430 \\
1830 \\
2230\end{array}$ & $\begin{array}{l}.62 \\
.62 \\
.59 \\
.56 \\
.56 \\
.54 \\
.54 \\
.51\end{array}$ & $\begin{array}{l}41 \\
40 \\
41 \\
42 \\
38 \\
43 \\
40 \\
39\end{array}$ & $\begin{array}{l}5.38 \\
5.40 \\
5.41 \\
5.39 \\
5.45 \\
5.44 \\
5.51 \\
5.50\end{array}$ & $\begin{array}{l}-2 \\
-2 \\
-1 \\
-- \\
-\overline{1}\end{array}$ & $\begin{array}{c}-2 \\
-2 \\
3.7 \\
-- \\
-- \\
3.7\end{array}$ & 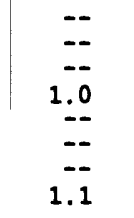 & $\begin{array}{c}-. \\
-- \\
1.2 \\
-- \\
-- \\
-\overline{1.3}\end{array}$ & $\begin{array}{l}-- \\
-- \\
-\overline{.76} \\
-- \\
-- \\
.72\end{array}$ & $\begin{array}{l}-- \\
-- \\
1.0 \\
-- \\
-- \\
1.0\end{array}$ & $\begin{array}{l}-- \\
-- \\
-- \\
11 \\
-- \\
-\therefore \\
11\end{array}$ \\
\hline $\begin{array}{l}23 \\
23 \\
23 \\
23 \\
\end{array}$ & $\begin{array}{l}0230 \\
0630 \\
1030 \\
1430 \\
\end{array}$ & $\begin{array}{l}.48 \\
.48 \\
.42 \\
.40 \\
\end{array}$ & $\begin{array}{l}38 \\
38 \\
40 \\
40 \\
\end{array}$ & $\begin{array}{l}5.62 \\
5.63 \\
5.60 \\
5.60 \\
\end{array}$ & $\begin{array}{l}-- \\
-1 \\
\end{array}$ & $\begin{array}{r}-- \\
3.7 \\
--\end{array}$ & $\begin{array}{r}\ldots \\
1.1 \\
\end{array}$ & $\begin{array}{r}-- \\
1.4 \\
--\end{array}$ & $\begin{array}{c}-- \\
.70 \\
-\end{array}$ & $\begin{array}{r}-- \\
-- \\
-\end{array}$ & $\ddot{--}$ \\
\hline Date & $\begin{array}{l}\text { Chlo- } \\
\text { ride, } \\
\text { dis- } \\
\text { solved } \\
\text { (ms/L) }\end{array}$ & $\begin{array}{l}\text { Fluo- } \\
\text { ride, } \\
\text { dis- } \\
\text { solved } \\
(\mathrm{mg} / \mathrm{L})\end{array}$ & $\begin{array}{l}\text { Bromide, } \\
\text { dis- } \\
\text { solved } \\
\text { (ms/L) }\end{array}$ & $\begin{array}{l}\text { Silica, } \\
\text { dis- } \\
\text { solved } \\
(\mathrm{mg} / \mathrm{L})\end{array}$ & $\begin{array}{l}\text { Nitro- } \\
\text { gen } \\
\text { ammonia, } \\
\text { dis- } \\
\text { solved } \\
\text { (mg/L } \\
\text { as N) }\end{array}$ & $\begin{array}{l}\text { Fhos- } \\
\text { phorus, } \\
\text { ortho, } \\
\text { dis- } \\
\text { solved } \\
\text { (mg/L) }\end{array}$ & $\begin{array}{l}\text { Alum- } \\
\text { Inum, } \\
\text { dis- } \\
\text { solved } \\
\text { (Hg/L) }\end{array}$ & $\begin{array}{l}\text { Iron, } \\
\text { dis- } \\
\text { solved } \\
(\mu g / L)\end{array}$ & $\begin{array}{l}\text { Manga- } \\
\text { nese, } \\
\text { dis- } \\
\text { solved } \\
(\mu g / L)\end{array}$ & $\begin{array}{l}\text { Carbon, } \\
\text { organic, } \\
\text { dis- } \\
\text { solved } \\
\text { (mg/L) }\end{array}$ & $\begin{array}{l}\text { Nitrogen } \\
\text { nitrate, } \\
\text { dissolved } \\
\text { (mg/L } \\
\text { as N) }\end{array}$ \\
\hline \multicolumn{12}{|l|}{ DEC } \\
\hline $\begin{array}{l}21 \\
21 \\
21 \\
21 \\
21 \\
21 \\
21 \\
21 \\
21 \\
21 \\
21 \\
21\end{array}$ & $\begin{array}{r}-- \\
2.3 \\
-. \\
2.3 \\
2.3 \\
-. \\
-- \\
2.1 \\
-. \\
2.1 \\
2.1\end{array}$ & \begin{tabular}{l}
-- \\
- \\
0.09 \\
.- \\
.08 \\
.08 \\
\hdashline- \\
.07 \\
.09 \\
.09
\end{tabular} & $\begin{array}{l}- \\
0.02 \\
0.02 \\
.02 \\
.02 \\
-0 \\
.02 \\
.02 \\
.02\end{array}$ & $\begin{array}{r}-2 \\
-- \\
4.1 \\
-.0 \\
3.9 \\
4.0 \\
-- \\
-- \\
4.0 \\
--0 \\
4.0 \\
4.0\end{array}$ & $\begin{array}{l}-. \\
0.005 \\
-0 \\
.005 \\
.138 \\
- \\
.005 \\
-0 \\
.04 \\
.005\end{array}$ & $\begin{array}{l}-- \\
0.01 \\
-0 \\
.01 \\
.004 \\
-2 \\
-- \\
.01 \\
-0 \\
.01 \\
.01\end{array}$ & $\begin{array}{r}-- \\
-- \\
50 \\
-\overline{60} \\
100 \\
-\overline{-} \\
\overline{90} \\
-\overline{-} \\
110 \\
140\end{array}$ & $\begin{array}{r}-- \\
-- \\
5 \\
-15 \\
22 \\
-- \\
-- \\
5 \\
-5 \\
14\end{array}$ & $\begin{array}{c}-- \\
-- \\
34 \\
-\overline{30} \\
5 \\
-- \\
-- \\
50 \\
-- \\
54 \\
60\end{array}$ & $\begin{array}{l}-- \\
-- \\
-- \\
-- \\
-- \\
-- \\
-- \\
-- \\
--\end{array}$ & $\begin{array}{l}-- \\
-- \\
0.65 \\
-- \\
- \\
- \\
-- \\
- \\
.58 \\
-- \\
.60 \\
.66\end{array}$ \\
\hline $\begin{array}{l}22 \\
22 \\
22 \\
22 \\
22 \\
22 \\
22 \\
22\end{array}$ & $\begin{array}{c}-- \\
-- \\
2.3 \\
-- \\
\overline{-} \\
2.2\end{array}$ & $\begin{array}{l}=- \\
-- \\
.08 \\
-\therefore \\
-0 \\
.07\end{array}$ & $\begin{array}{l}- \\
-- \\
- \\
.02 \\
-- \\
- \\
.02\end{array}$ & 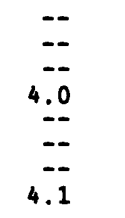 & $\begin{array}{l}-- \\
-- \\
.022 \\
-- \\
-\overline{-0} \\
.005\end{array}$ & $\begin{array}{l}-- \\
-- \\
-01 \\
-\therefore \\
-\therefore \\
01\end{array}$ & $\begin{array}{r}-- \\
=- \\
130 \\
=- \\
-- \\
90\end{array}$ & $\begin{array}{l}-- \\
\therefore- \\
15 \\
-- \\
-- \\
4\end{array}$ & $\begin{array}{l}=- \\
-- \\
60 \\
-\therefore \\
\therefore- \\
48\end{array}$ & $\begin{array}{l}=- \\
-- \\
-- \\
=- \\
-- \\
--\end{array}$ & $\begin{array}{l}-- \\
-- \\
-- \\
.57 \\
-- \\
-- \\
--\end{array}$ \\
\hline $\begin{array}{l}23 \\
23 \\
23 \\
23 \\
\end{array}$ & $\begin{array}{r}-- \\
2.3 \\
--\end{array}$ & $\begin{array}{l}-- \\
-07 \\
--\end{array}$ & $\begin{array}{l}- \\
-0 \\
.0 \\
-\end{array}$ & $\begin{array}{l}\ldots \\
\ldots .0 \\
--\end{array}$ & $\begin{array}{l}\ldots \\
.017 \\
-\end{array}$ & -1 & 80 & $\begin{array}{l}-- \\
-- \\
27 \\
--\end{array}$ & $\begin{array}{l}-- \\
-- \\
44 \\
--\end{array}$ & $\begin{array}{l}-- \\
-- \\
--\end{array}$ & $\begin{array}{l}-- \\
-- \\
.69 \\
--\end{array}$ \\
\hline
\end{tabular}


Table 15.--Water-quality data for rainfall and snownelt runoff at North Fork Bens Creek at North Fork Reservolr, 1984-86--Continued

$\left[\mathrm{m}^{3} / \mathrm{s}\right.$, cubic meters per second; $\mu \mathrm{S} / \mathrm{cm}$, microsiemens per centimeter at 25 degrees Celsius; mg/L, milligrams per liter; $\mu \mathrm{g} / \mathrm{L}$, micrograms per liter; <, less than; --, indicates no data]

\begin{tabular}{|c|c|c|c|c|c|c|c|c|c|c|c|}
\hline Date & Time & $\begin{array}{l}\text { Stream- } \\
\text { flow, } \\
\text { Instan- } \\
\text { taneous } \\
\left(\mathrm{m}^{3} / \mathrm{s}\right)\end{array}$ & $\begin{array}{l}\text { Spe- } \\
\text { cific } \\
\text { con- } \\
\text { duct- } \\
\text { ance } \\
(\mu S / \mathrm{cm})\end{array}$ & $\begin{array}{l}\text { pH } \\
\text { (stand- } \\
\text { ard } \\
\text { units) }\end{array}$ & $\begin{array}{l}\text { Acidity } \\
(\mathrm{mg} / \mathrm{L} \\
\text { as } \mathrm{H}^{+} \text {) }\end{array}$ & $\begin{array}{l}\text { Calcium, } \\
\text { dis- } \\
\text { solved } \\
\text { (mg/L) }\end{array}$ & $\begin{array}{l}\text { Magne- } \\
\text { sium, } \\
\text { dis- } \\
\text { solved } \\
\text { (mg/L) }\end{array}$ & $\begin{array}{l}\text { Sodium, } \\
\text { dis- } \\
\text { solved } \\
\text { (mg/L) }\end{array}$ & $\begin{array}{l}\text { Potas- } \\
\text { sium, } \\
\text { dis- } \\
\text { solved } \\
\text { (mg/L) }\end{array}$ & $\begin{array}{l}\text { Alka- } \\
\text { linity, } \\
\text { lab } \\
\text { (mg/L } \\
\text { as } \\
\mathrm{CaCO}_{3} \text { ) }\end{array}$ & $\begin{array}{l}\text { Sulfate, } \\
\text { dis- } \\
\text { solved } \\
\text { (mg/L) }\end{array}$ \\
\hline \multicolumn{12}{|c|}{1985} \\
\hline $\begin{array}{l}22 \\
22 \\
22 \\
22 \\
22 \\
22 \\
22 \\
22 \\
22 \\
22 \\
22\end{array}$ & $\begin{array}{l}1030 \\
1200 \\
1215 \\
1315 \\
1415 \\
1515 \\
1615 \\
1715 \\
1915 \\
2115 \\
2315\end{array}$ & $\begin{array}{r}0.12 \\
.13 \\
.13 \\
.15 \\
.18 \\
.19 \\
.20 \\
.21 \\
.22 \\
.23 \\
.25\end{array}$ & $\begin{array}{l}43 \\
44 \\
43 \\
44 \\
43 \\
43 \\
41 \\
43 \\
43 \\
44 \\
44\end{array}$ & $\begin{array}{l}5.72 \\
5.99 \\
5.70 \\
5.73 \\
5.59 \\
5.53 \\
5.63 \\
5.50 \\
5.38 \\
5.60 \\
5.58\end{array}$ & $\begin{array}{r}<0.1 \\
-- \\
=- \\
-- \\
<.1 \\
-- \\
<.1 \\
-- \\
--\end{array}$ & $\begin{array}{r}3.4 \\
-- \\
-- \\
-- \\
3.3 \\
-\overline{3.6} \\
-- \\
--\end{array}$ & $\begin{array}{c}1.0 \\
-- \\
-- \\
-- \\
1.0 \\
-\overline{0} \\
1.1 \\
-- \\
--\end{array}$ & $\begin{array}{c}1.3 \\
-- \\
-- \\
-- \\
1.2 \\
-- \\
1.2 \\
-- \\
--\end{array}$ & $\begin{array}{l}0.55 \\
-- \\
-- \\
-- \\
-- \\
.57 \\
-- \\
.65 \\
-- \\
--\end{array}$ & $\begin{array}{c}1.0 \\
-- \\
-- \\
-- \\
1.0 \\
-- \\
1.0 \\
-- \\
--\end{array}$ & $\begin{array}{c}9.4 \\
-- \\
-- \\
-- \\
9.4 \\
-\overline{-} \\
9.4 \\
-- \\
-- \\
--\end{array}$ \\
\hline $\begin{array}{l}23 \\
23 \\
23 \\
23 \\
23 \\
23 \\
23 \\
23 \\
23 \\
23 \\
23 \\
23\end{array}$ & $\begin{array}{l}0315 \\
0715 \\
1115 \\
1200 \\
1300 \\
1400 \\
1500 \\
1600 \\
1700 \\
1900 \\
2100 \\
2300\end{array}$ & $\begin{array}{l}.26 \\
.27 \\
.31 \\
.31 \\
.34 \\
.45 \\
.54 \\
.59 \\
.68 \\
.82 \\
.88 \\
.88\end{array}$ & $\begin{array}{l}44 \\
44 \\
43 \\
42 \\
42 \\
43 \\
44 \\
44 \\
44 \\
45 \\
44 \\
44\end{array}$ & $\begin{array}{l}5.55 \\
5.55 \\
5.52 \\
5.57 \\
5.57 \\
5.49 \\
5.48 \\
5.48 \\
5.41 \\
5.35 \\
5.32 \\
5.30\end{array}$ & $\begin{array}{r}<.1 \\
<.1 \\
<.1 \\
<.1 \\
<.1 \\
<.1 \\
<.1 \\
<.1 \\
-.\end{array}$ & $\begin{array}{r}3.6 \\
3.5 \\
-- \\
3.3 \\
3 .- \\
-.5 \\
3.5 \\
3.3\end{array}$ & $\begin{array}{r}1.1 \\
1.1 \\
-- \\
1.0 \\
1.0 \\
-0 \\
1.0 \\
1.0 \\
-.\end{array}$ & $\begin{array}{l}1.1 \\
1.0 \\
-- \\
-.90 \\
.9 \\
.80 \\
.80 \\
.80 \\
.-\end{array}$ & $\begin{array}{l}.59 \\
.6 \\
.68 \\
-- \\
.57 \\
-.5 \\
.56 \\
-.63 \\
.59 \\
-.\end{array}$ & $\begin{array}{r}1.0 \\
1.0 \\
-- \\
--0 \\
1.0 \\
-0 \\
1.0 \\
1.0\end{array}$ & $\begin{array}{l}10^{--} \\
11^{--} \\
11^{--} \\
10^{--} \\
111^{--} \\
11\end{array}$ \\
\hline $\begin{array}{l}24 \\
24 \\
24\end{array}$ & $\begin{array}{l}0300 \\
0700 \\
1100\end{array}$ & $\begin{array}{r}.82 \\
.79 \\
1.13\end{array}$ & $\begin{array}{l}43 \\
44 \\
44\end{array}$ & $\begin{array}{l}5.36 \\
5.39 \\
5.32\end{array}$ & $\begin{array}{l}-. \\
<.1 \\
<.1\end{array}$ & $\begin{array}{r}-- \\
3.6 \\
3.5\end{array}$ & $\begin{array}{l}-. \\
1.0 \\
1.0\end{array}$ & $\begin{array}{l}-- \\
.80 \\
.80\end{array}$ & $\begin{array}{l}-. \\
.63 \\
.64\end{array}$ & $\begin{array}{l}-\overline{0} \\
1.0 \\
1.0\end{array}$ & $11^{--}$ \\
\hline $\begin{array}{l}26 \\
26 \\
26 \\
26\end{array}$ & $\begin{array}{l}1045 \\
1415 \\
1815 \\
2215\end{array}$ & $\begin{array}{l}.93 \\
.91 \\
.88 \\
.79\end{array}$ & $\begin{array}{l}44 \\
42 \\
42 \\
41\end{array}$ & $\begin{array}{l}5.23 \\
5.28 \\
5.27 \\
5.30\end{array}$ & $\begin{array}{l}-- \\
<.1 \\
<.1\end{array}$ & $\begin{array}{r}3 .- \\
3 .- \\
3.2\end{array}$ & $\begin{array}{c}-. \\
1.0 \\
.90\end{array}$ & $\frac{--}{1.1}$ & $\begin{array}{l}-- \\
.68 \\
.61\end{array}$ & $\begin{array}{l}-- \\
1.0 \\
1.0\end{array}$ & $10^{--}$ \\
\hline $\begin{array}{l}27 \\
27 \\
27 \\
27 \\
27 \\
27\end{array}$ & $\begin{array}{l}0215 \\
0615 \\
1015 \\
1415 \\
1815 \\
2215\end{array}$ & $\begin{array}{l}.71 \\
.65 \\
.68 \\
.62 \\
.59 \\
.57\end{array}$ & $\begin{array}{l}41 \\
41 \\
42 \\
42 \\
41 \\
41\end{array}$ & $\begin{array}{l}5.28 \\
5.24 \\
5.31 \\
5.38 \\
5.40 \\
5.34\end{array}$ & $\begin{array}{l}-- \\
<.1 \\
<.1 \\
-- \\
-- \\
--\end{array}$ & $\begin{array}{r}-- \\
3.2 \\
3.3 \\
-- \\
=- \\
--\end{array}$ & $\begin{array}{l}-- \\
.90 \\
.90 \\
=- \\
=- \\
--\end{array}$ & $\begin{array}{l}-- \\
1.1 \\
1.2 \\
-- \\
--\end{array}$ & $\begin{array}{l}-- \\
.59 \\
.66 \\
-- \\
-- \\
--\end{array}$ & $\begin{array}{l}-- \\
1.0 \\
1.0 \\
=- \\
--\end{array}$ & $\begin{array}{l}10^{--} \\
10^{--} \\
-- \\
--\end{array}$ \\
\hline $\begin{array}{l}28 \\
28\end{array}$ & $\begin{array}{l}0215 \\
0615\end{array}$ & $\begin{array}{l}.54 \\
.51\end{array}$ & $\begin{array}{l}41 \\
41\end{array}$ & $\begin{array}{l}5.32 \\
5.39\end{array}$ & $<.1$ & $3 . \overline{5}$ & $1 . \overline{0}$ & $1 . \overline{4}$ & $-\overline{.65}$ & $1 . \overline{0}$ & $10^{--}$ \\
\hline \multicolumn{12}{|l|}{ MAR } \\
\hline 01 & 1245 & .40 & 41 & 5.52 & $<.1$ & 3.2 & .90 & 1.3 & .61 & 1.0 & 10 \\
\hline
\end{tabular}


Table 15. - Water-quality data for rainfall and snownelt runoff at North Fork Bens Creek at North Fork Reservoir, 1984-86-Continued

$\left[\mathrm{m}^{3} / \mathrm{s}\right.$, cubic meters per second; $\mathrm{kS} / \mathrm{cm}$, midrosiemens per centimeter at 25 degrees Celsius; mg/L, milligfams per liter; $\mu 8 / L$, micrograms per liter; <, less than; --, indicates no data]

\begin{tabular}{|c|c|c|c|c|c|c|c|c|c|c|c|}
\hline Date & $\begin{array}{l}\text { Chlo- } \\
\text { ride, } \\
\text { dis- } \\
\text { solved } \\
(\mathrm{mg} / \mathrm{L})\end{array}$ & $\begin{array}{l}\text { Fluo- } \\
\text { ride, } \\
\text { dis- } \\
\text { solved } \\
\text { (mg/L) }\end{array}$ & $\begin{array}{l}\text { Bromide, } \\
\text { dis- } \\
\text { solved } \\
\text { (ms/L) }\end{array}$ & $\begin{array}{l}\text { Silica, } \\
\text { dis- } \\
\text { solved } \\
\text { (mg/L) }\end{array}$ & $\begin{array}{l}\text { Nitro- } \\
\text { gen } \\
\text { ammonia, } \\
\text { dis- } \\
\text { solved } \\
\text { (mg/L } \\
\text { as N) }\end{array}$ & $\begin{array}{l}\text { Ehos- } \\
\text { phorus, } \\
\text { oftho, } \\
\text { dis- } \\
\text { splved } \\
\text { (ns/L) }\end{array}$ & $\begin{array}{l}\text { Alum- } \\
\text { inum, } \\
\text { dis- } \\
\text { solved } \\
(\mu 8 / L)\end{array}$ & $\begin{array}{l}\text { Iron, } \\
\text { dis- } \\
\text { solved } \\
(\mu g / L)\end{array}$ & $\begin{array}{l}\text { Manga- } \\
\text { nese, } \\
\text { dis- } \\
\text { solved } \\
(\mu g / L)\end{array}$ & $\begin{array}{l}\text { Carbon, } \\
\text { organic, } \\
\text { dis- } \\
\text { solved } \\
\text { (mg/L) }\end{array}$ & $\begin{array}{l}\text { Nitrogen } \\
\text { nitrate, } \\
\text { dissolved } \\
(\mathrm{mg} / \mathrm{I} \\
\text { as } N \text { ) }\end{array}$ \\
\hline FEB & \multicolumn{11}{|c|}{1985} \\
\hline $\begin{array}{l}22 \\
22 \\
22 \\
22 \\
22 \\
22 \\
22 \\
22 \\
22 \\
22 \\
22\end{array}$ & $\begin{array}{r}2.6 \\
-- \\
-- \\
-- \\
-- \\
2.0 \\
-\overline{2} \\
-2 \\
-- \\
--\end{array}$ & $\begin{array}{l}0.06 \\
-- \\
-- \\
-- \\
-- \\
.06 \\
-- \\
.22 \\
-- \\
-- \\
--\end{array}$ & $\begin{array}{l}0.03 \\
-- \\
-- \\
-- \\
-- \\
.03 \\
-\overline{0} \\
.03 \\
-- \\
-- \\
--\end{array}$ & $\begin{array}{r}3.5 \\
-- \\
-- \\
-- \\
-- \\
3.4 \\
-\overline{3} \\
3.6 \\
-- \\
-- \\
--\end{array}$ & $\begin{array}{l}0.008 \\
-- \\
-- \\
-- \\
-- \\
.015 \\
-\overline{0} \\
.014 \\
-- \\
-- \\
--\end{array}$ & $\begin{array}{l}0.010 \\
=- \\
- \\
- \\
-010 \\
-010 \\
.010 \\
= \\
-\end{array}$ & $\begin{array}{l}40 \\
=- \\
=- \\
=- \\
70 \\
-- \\
60 \\
-- \\
-2\end{array}$ & $\begin{array}{r}5 \\
-- \\
-- \\
-- \\
-- \\
3 \\
-- \\
3 \\
-- \\
-- \\
--\end{array}$ & $\begin{array}{l}17 \\
-- \\
-- \\
-- \\
-- \\
29 \\
-- \\
41 \\
-- \\
-- \\
--\end{array}$ & $\begin{array}{l}0.40 \\
=- \\
=- \\
=- \\
-- \\
.80 \\
=- \\
=- \\
= \\
=\end{array}$ & $\begin{array}{l}0.76 \\
-- \\
-- \\
-- \\
-- \\
.80 \\
-83 \\
-- \\
=-\end{array}$ \\
\hline $\begin{array}{l}23 \\
23 \\
23 \\
23 \\
23 \\
23 \\
23 \\
23 \\
23 \\
23 \\
23 \\
23\end{array}$ & $\begin{array}{r}1.9 \\
-. \\
1.8 \\
-- \\
-- \\
1.0 \\
--0 \\
1.6 \\
-- \\
1.4 \\
1.4 \\
--\end{array}$ & $\begin{array}{l}.08 \\
-- \\
.10 \\
-- \\
-- \\
.07 \\
-- \\
.07 \\
-- \\
.07 \\
.07 \\
--\end{array}$ & $\begin{array}{l}.03 \\
-- \\
.03 \\
-- \\
-- \\
.03 \\
-- \\
.03 \\
-- \\
.03 \\
.03 \\
--\end{array}$ & $\begin{array}{r}3.6 \\
-- \\
3.6 \\
-- \\
-- \\
3.4 \\
-- \\
3.0 \\
-- \\
3.2 \\
3.1 \\
--\end{array}$ & $\begin{array}{l}.012 \\
-0 \\
.008 \\
-- \\
-0 \\
.013 \\
-0 \\
.014 \\
-0 \\
.014 \\
.012 \\
--\end{array}$ & $\begin{array}{l}.010 \\
-010 \\
-- \\
-010 \\
-0 \\
.010 \\
-010 \\
.010 \\
--\end{array}$ & $\begin{array}{r}110 \\
110 \\
-0 \\
120 \\
130 \\
180 \\
180 \\
190 \\
0\end{array}$ & $\begin{array}{r}5 \\
-- \\
-5 \\
-- \\
4 \\
-- \\
6 \\
-- \\
8 \\
8 \\
--\end{array}$ & $\begin{array}{l}55 \\
-- \\
55 \\
-- \\
-- \\
56 \\
-- \\
67 \\
-- \\
88 \\
88 \\
--\end{array}$ & $\begin{array}{c}1.2 \\
-- \\
-- \\
-- \\
- \\
.90 \\
-- \\
-- \\
-- \\
-- \\
-- \\
--\end{array}$ & $\begin{array}{l}.83 \\
-- \\
.78 \\
-- \\
-- \\
.88 \\
-.84 \\
.84 \\
.88 \\
.88\end{array}$ \\
\hline $\begin{array}{l}24 \\
24 \\
24\end{array}$ & $\begin{array}{r}--\overline{3} \\
1.4\end{array}$ & $\begin{array}{l}-. \\
.07 \\
.07\end{array}$ & $\begin{array}{l}-.03 \\
.03\end{array}$ & $\begin{array}{l}--\overline{1} \\
3.6 \\
3.4\end{array}$ & $\begin{array}{l}-. \\
.010 \\
.010\end{array}$ & $\begin{array}{l}-. \\
.010 \\
.010\end{array}$ & $\begin{array}{l}180 \\
180\end{array}$ & $\begin{array}{r}-- \\
4 \\
7\end{array}$ & $\begin{array}{l}-- \\
74 \\
79\end{array}$ & $\begin{array}{c}-- \\
1.1\end{array}$ & $\begin{array}{l}.88 \\
.91\end{array}$ \\
\hline $\begin{array}{l}26 \\
26 \\
26 \\
26\end{array}$ & $\begin{array}{r}--\overline{3} \\
2 . \overline{2}\end{array}$ & $\begin{array}{l}-\overline{13} \\
.13 \\
.09\end{array}$ & $\begin{array}{l}-\overline{.03} \\
-0 \\
.10\end{array}$ & $\begin{array}{r}3.7 \\
-- \\
3.3\end{array}$ & $\begin{array}{l}-\overline{-} \\
.038 \\
-0 \\
.031\end{array}$ & $\begin{array}{l}-010 \\
-010\end{array}$ & $\begin{array}{l}\overline{180} \\
\overline{100}\end{array}$ & $\begin{array}{r}-- \\
-5 \\
6\end{array}$ & $\begin{array}{l}-\overline{68} \\
-- \\
55\end{array}$ & $\begin{array}{l}-- \\
-- \\
-- \\
--\end{array}$ & $\begin{array}{l}-\overline{-} \\
.98 \\
.98\end{array}$ \\
\hline $\begin{array}{l}27 \\
27 \\
27 \\
27 \\
27 \\
27\end{array}$ & $\begin{array}{r}-- \\
2.3 \\
2.3 \\
-- \\
-- \\
--\end{array}$ & $\begin{array}{l}-- \\
.08 \\
.05 \\
-- \\
-- \\
--\end{array}$ & $\begin{array}{l}- \\
.03 \\
.03 \\
-- \\
-- \\
--\end{array}$ & $\begin{array}{r}-. \\
3.3 \\
3.4 \\
-. \\
-- \\
--\end{array}$ & $\begin{array}{l}-. \\
.013 \\
.022 \\
-- \\
-- \\
--\end{array}$ & $\begin{array}{l}-. \\
.010 \\
.010 \\
-- \\
-- \\
--\end{array}$ & $\begin{array}{r}120 \\
120 \\
=- \\
--\end{array}$ & $\begin{array}{r}-- \\
4 \\
4 \\
-- \\
-- \\
--\end{array}$ & $\begin{array}{l}-- \\
50 \\
55 \\
-- \\
-- \\
--\end{array}$ & $\begin{array}{l}-- \\
-- \\
-- \\
--\end{array}$ & $\begin{array}{l}-- \\
.98 \\
.99 \\
-- \\
-- \\
--\end{array}$ \\
\hline $\begin{array}{l}28 \\
28\end{array}$ & $2 . \overline{6}$ & .07 & .03 & $3 . \overline{8}$ & .027 & .010 & 120 & $-\frac{-}{5}$ & $\overline{50}$ & $=$ & .95 \\
\hline \multicolumn{12}{|l|}{ MAR } \\
\hline 01 & 2.7 & .06 & .03 & 3.5 & .006 & .010 & 100 & 4 & 39 & -- & .91 \\
\hline
\end{tabular}


Table 15.--Water-quality data for rainfall and snowmelt runoff at North Fork Bens Creek at North Fork Reservolr, 1984-86--Continued

$\left[\mathrm{m}^{3} / \mathrm{s}\right.$, cubic meters per second; $\mu \mathrm{S} / \mathrm{cm}$, microsiemens per centimeter at 25 degrees Celsius; mg/L, milligrams per liter; $\mu 8 / L$, micrograms per liter; <, less than; --, indicates no data]

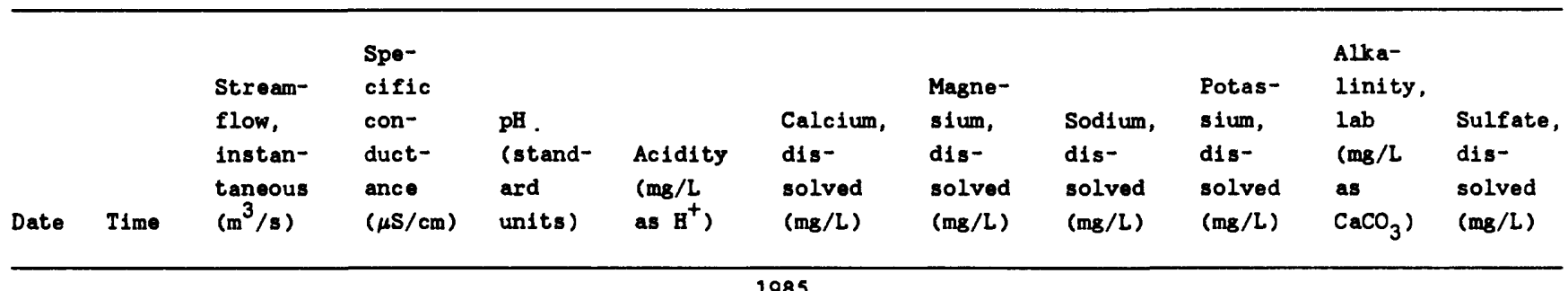

MAR

\begin{tabular}{rrr}
12 & 0230 & 0.28 \\
12 & 0330 & .34 \\
12 & 0430 & .42 \\
12 & 0530 & .45 \\
12 & 0630 & .48 \\
12 & 0730 & .51 \\
12 & 0930 & .48 \\
12 & 1130 & .45 \\
12 & 1330 & .42 \\
12 & 1730 & .40 \\
12 & 2130 & .40 \\
13 & 0130 & .37 \\
\hline
\end{tabular}

\begin{tabular}{|c|c|c|}
\hline $\begin{array}{l}43 \\
43 \\
43 \\
42 \\
42 \\
45 \\
44 \\
44 \\
44 \\
45 \\
44\end{array}$ & $\begin{array}{l}5.68 \\
5.70 \\
5.59 \\
5.51 \\
5.50 \\
5.40 \\
5.41 \\
5.41 \\
5.37 \\
5.40 \\
5.50\end{array}$ & $\begin{array}{l}0.040 \\
-0 \\
.037 \\
-0 \\
.014 \\
.013 \\
-- \\
.024 \\
=- \\
.044 \\
--\end{array}$ \\
\hline
\end{tabular}

2.8
2.9
3.3
3.3
3.0
3.3
---
3.3

0.70
.-90
.90
.99
.95
.9
.90
.99
.-

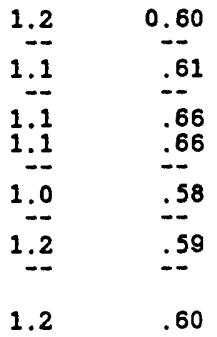

1.9
-5
.50
.50
.50
-5
.50
.50
--

9.7

$-0$

$\because 61$

.66

.58

.59

1.0

1.2

.60

$.50 \quad 11$

\begin{tabular}{|c|c|c|c|c|c|c|c|c|c|c|c|}
\hline Date & $\begin{array}{l}\text { Chlo- } \\
\text { ride, } \\
\text { dis- } \\
\text { solved } \\
(\mathrm{mg} / \mathrm{L})\end{array}$ & $\begin{array}{l}\text { Fluo- } \\
\text { ride, } \\
\text { dis- } \\
\text { solved } \\
\text { (mg/L) }\end{array}$ & $\begin{array}{l}\text { Bromide, } \\
\text { dis- } \\
\text { solved } \\
\text { (mg/L) }\end{array}$ & $\begin{array}{l}\text { Silica, } \\
\text { dis- } \\
\text { solved } \\
(\mathrm{mg} / \mathrm{L})\end{array}$ & $\begin{array}{l}\text { Nitro- } \\
\text { gen } \\
\text { ammonia, } \\
\text { dis- } \\
\text { solved } \\
\text { (mg/L } \\
\text { as N) }\end{array}$ & $\begin{array}{l}\text { Phos- } \\
\text { phorus, } \\
\text { ortho, } \\
\text { dis- } \\
\text { solved } \\
\text { (mg/L) }\end{array}$ & $\begin{array}{l}\text { Alum- } \\
\text { Inum, } \\
\text { dis- } \\
\text { solved } \\
(\mu g / L)\end{array}$ & $\begin{array}{l}\text { Iron, } \\
\text { dis- } \\
\text { solved } \\
(\mu \mathrm{g} / \mathrm{L})\end{array}$ & $\begin{array}{l}\text { Manga- } \\
\text { nese, } \\
\text { dis- } \\
\text { solved } \\
\left(\mu_{g} / L\right)\end{array}$ & $\begin{array}{l}\text { Carbon, } \\
\text { organic, } \\
\text { dis- } \\
\text { solved } \\
\text { (mg/L) }\end{array}$ & $\begin{array}{l}\text { Nitrogen } \\
\text { nitrate, } \\
\text { dissolved } \\
\text { (mg/L } \\
\text { as } N \text { ) }\end{array}$ \\
\hline MAR & & , & & & & & & & & & \\
\hline $\begin{array}{l}12 \\
12 \\
12 \\
12 \\
12 \\
12 \\
12 \\
12 \\
12 \\
12\end{array}$ & $\begin{array}{r}2.9 \\
2.7 \\
-- \\
2.4 \\
2.4 \\
--\overline{2} \\
2.4 \\
-- \\
2.4 \\
--\end{array}$ & $\begin{array}{l}0.05 \\
.06 \\
-- \\
.06 \\
.06 \\
-- \\
.06 \\
-0 \\
.06 \\
=-\end{array}$ & $\begin{array}{l}0.02 \\
.02 \\
-- \\
.02 \\
.02 \\
-02 \\
.02 \\
.02\end{array}$ & $\begin{array}{r}3.0 \\
3.0 \\
-0 \\
3.3 \\
3.4 \\
--2 \\
3.1 \\
-- \\
3.4 \\
--\end{array}$ & $\begin{array}{c}0.009 \\
.008 \\
.0 \\
.011 \\
.005 \\
- \\
.012 \\
.0 \\
.013 \\
.\end{array}$ & $\begin{array}{c}0.001 \\
.001 \\
-0 \\
.001 \\
.001 \\
-- \\
.001 \\
-0 \\
.001 \\
.\end{array}$ & $\begin{array}{r}50 \\
80 \\
-0 \\
100 \\
110 \\
120 \\
120\end{array}$ & $\begin{array}{r}2 \\
3 \\
-- \\
2 \\
2 \\
-- \\
-2 \\
-2 \\
--\end{array}$ & $\begin{array}{l}27 \\
35 \\
-- \\
46 \\
50 \\
-- \\
48 \\
-- \\
47 \\
---\end{array}$ & $\begin{array}{r}1.2 \\
1.6 \\
-.0 \\
1.3 \\
2.0 \\
-0 \\
1.5 \\
1.0 \\
-.0\end{array}$ & $\begin{array}{l}0.77 \\
.75 \\
-\div \\
.75 \\
.74 \\
-- \\
.74 \\
--7 \\
.76\end{array}$ \\
\hline 13 & 2.4 & .06 & .02 & 3.6 & .009 & .001 & 100 & 2 & 46 & 1.1 & .78 \\
\hline
\end{tabular}


Table 15. - Water-quality data for rainfali and snowmelt runoff at North Fork Bens Creek at North Fork Reservoir, 1984-86-Continued

$\left[\mathrm{m}^{3} / \mathrm{s}\right.$, cubic meters per second; $\mu \mathrm{s} / \mathrm{cm}$, qicrosiemens per centimeter at

25 degrees Celsius; mg/L, milligrams pef liter; $\mu 8 / L$, micrograms per

liter; <, less than; --, indicates no data]

\begin{tabular}{|c|c|c|c|c|c|c|c|c|c|c|c|}
\hline Date & Time & $\begin{array}{l}\text { Stream- } \\
\text { flow, } \\
\text { instan- } \\
\text { taneous } \\
\left(\mathrm{m}^{3} / \mathrm{s}\right)\end{array}$ & $\begin{array}{l}\text { Spe- } \\
\text { cific } \\
\text { con- } \\
\text { duct- } \\
\text { ance } \\
(\mu \mathrm{S} / \mathrm{cm})\end{array}$ & $\begin{array}{l}\text { pH } \\
\text { (stand- } \\
\text { ard } \\
\text { units) }\end{array}$ & $\begin{array}{l}\text { Acidity } \\
\text { (mg/L } \\
\text { as } \mathrm{H}^{+} \text {) }\end{array}$ & $\begin{array}{l}\text { Calcium, } \\
\text { dis- } \\
\text { solved } \\
\text { (mg/L) }\end{array}$ & $\begin{array}{l}\text { Magne- } \\
\text { sium, } \\
\text { dis- } \\
\text { solved } \\
\text { (mg/L) }\end{array}$ & $\begin{array}{l}\text { Sodium, } \\
\text { dis- } \\
\text { solved } \\
\text { (mg/L) }\end{array}$ & $\begin{array}{l}\text { Potas- } \\
\text { sium, } \\
\text { dis- } \\
\text { solved } \\
\text { (mg/L) }\end{array}$ & $\begin{array}{l}\text { Alka- } \\
\text { linity, } \\
\text { lab } \\
(\mathrm{mg} / \mathrm{L} \\
\text { as } \\
\left.\mathrm{CaCO}_{3}\right)\end{array}$ & $\begin{array}{l}\text { Sulfate, } \\
\text { dis- } \\
\text { solved } \\
(\mathrm{mg} / \mathrm{L})\end{array}$ \\
\hline $\begin{array}{r}\text { MAY } \\
02 \\
02 \\
02 \\
02 \\
02 \\
02 \\
02 \\
02 \\
02 \\
02\end{array}$ & $\begin{array}{l}0800 \\
0900 \\
1000 \\
1100 \\
1200 \\
1400 \\
1600 \\
1800 \\
2000 \\
2400\end{array}$ & $\begin{array}{l}0.11 \\
.11 \\
.11 \\
.11 \\
.11 \\
.12 \\
.18 \\
.24 \\
.23 \\
.42\end{array}$ & $\begin{array}{l}45 \\
45 \\
45 \\
45 \\
45 \\
45 \\
45 \\
44 \\
43 \\
42\end{array}$ & $\begin{array}{l}5.86 \\
6.08 \\
6.00 \\
6.00 \\
5.99 \\
6.08 \\
5.99 \\
5.87 \\
5.81 \\
5.75\end{array}$ & $\begin{array}{c}<0.05 \\
-- \\
\cdots \\
\cdots \\
<0.05 \\
<0.05 \\
-- \\
<0.05\end{array}$ & $\begin{array}{r}985 \\
3.0 \\
-- \\
-- \\
-- \\
-- \\
3.7 \\
2.8 \\
-- \\
-- \\
2.8\end{array}$ & $\begin{array}{c}0.8 \\
-- \\
-- \\
-- \\
-- \\
1.0 \\
.8 \\
-- \\
-- \\
.9\end{array}$ & $\begin{array}{r}1.6 \\
-- \\
-- \\
-- \\
-- \\
1.8 \\
1.4 \\
-- \\
=- \\
1.0\end{array}$ & $\begin{array}{l}0.71 \\
-- \\
-- \\
-- \\
-- \\
.67 \\
.85 \\
-- \\
-- \\
.83\end{array}$ & $\begin{array}{l}0.50 \\
-- \\
-- \\
-- \\
-- \\
.50 \\
.50 \\
-- \\
-- \\
.50\end{array}$ & $\begin{array}{r}9.3 \\
-- \\
-- \\
-- \\
-- \\
9.5 \\
9.8 \\
-- \\
10\end{array}$ \\
\hline $\begin{array}{l}03 \\
03 \\
03 \\
03 \\
03 \\
03 \\
03 \\
03 \\
03 \\
03 \\
03 \\
03\end{array}$ & $\begin{array}{l}0400 \\
0430 \\
0530 \\
0630 \\
0730 \\
0830 \\
0930 \\
1130 \\
1330 \\
1530 \\
1930 \\
2330\end{array}$ & $\begin{array}{r}.71 \\
.74 \\
1.08 \\
1.36 \\
1.42 \\
1.47 \\
1.39 \\
1.25 \\
1.25 \\
1.02 \\
.91 \\
.82\end{array}$ & $\begin{array}{l}41 \\
41 \\
41 \\
42 \\
42 \\
42 \\
43 \\
44 \\
45 \\
44 \\
44 \\
44\end{array}$ & $\begin{array}{l}5.49 \\
5.31 \\
5.31 \\
5.27 \\
5.23 \\
5.20 \\
5.19 \\
5.21 \\
5.22 \\
5.27 \\
5.30 \\
5.30\end{array}$ & $\begin{array}{l}<-- \\
<0.05 \\
<0.05 \\
<0.05 \\
<0.05 \\
<0.05 \\
-- \\
\cdots\end{array}$ & $\begin{array}{r}-- \\
-- \\
2.6 \\
-- \\
3.4 \\
2.3 \\
-- \\
3.4 \\
--5 \\
3.5 \\
-- \\
--\end{array}$ & $\begin{array}{r}-- \\
-- \\
.7 \\
-- \\
1.0 \\
.7 \\
-- \\
1.0 \\
-- \\
1.0 \\
=- \\
--\end{array}$ & $\begin{array}{l}-- \\
-- \\
.90 \\
-- \\
.90 \\
.70 \\
-- \\
.90 \\
-- \\
1.0 \\
-- \\
--\end{array}$ & $\begin{array}{l}-- \\
-- \\
.68 \\
-- \\
.78 \\
.54 \\
-- \\
.74 \\
-- \\
.75 \\
-- \\
--\end{array}$ & $\begin{array}{l}-- \\
-- \\
.50 \\
-- \\
.50 \\
.50 \\
-- \\
.50 \\
-- \\
.50 \\
-- \\
--\end{array}$ & $\begin{array}{c}10^{--} \\
10^{--} \\
10^{--} \\
10^{--} \\
10^{--} \\
-- \\
--\end{array}$ \\
\hline 04 & 0330 & .71 & 44 & 5.42 & $<0.05$ & 2.9 & .90 & .80 & .81 & .50 & 10 \\
\hline Date & $\begin{array}{l}\text { Chlo- } \\
\text { ride, } \\
\text { dis- } \\
\text { solved } \\
\text { (mg/L) }\end{array}$ & $\begin{array}{l}\text { Fluo- } \\
\text { ride, } \\
\text { dis- } \\
\text { solved } \\
\text { (mg/L) }\end{array}$ & $\begin{array}{l}\text { Bromide, } \\
\text { dis- } \\
\text { solved } \\
\text { (mg/L) }\end{array}$ & $\begin{array}{l}\text { Silica, } \\
\text { dis- } \\
\text { solved } \\
(\mathrm{mg} / \mathrm{L})\end{array}$ & $\begin{array}{l}\text { Nitro- } \\
\text { gen } \\
\text { ammonia, } \\
\text { dis- } \\
\text { solved } \\
\text { (mg/I } \\
\text { as } N \text { ) }\end{array}$ & $\begin{array}{l}\text { Phos- } \\
\text { phorus, } \\
\text { ortho, } \\
\text { dis- } \\
\text { solved } \\
\text { (mg/L) }\end{array}$ & $\begin{array}{l}\text { Alum- } \\
\text { inum, } \\
\text { dis- } \\
\text { solved } \\
(\mu g / L)\end{array}$ & $\begin{array}{l}\text { Iron, } \\
\text { dis- } \\
\text { solved } \\
(\mu g / L)\end{array}$ & $\begin{array}{l}\text { Manga- } \\
\text { nese, } \\
\text { dis- } \\
\text { solved } \\
(\mu g / L)\end{array}$ & $\begin{array}{l}\text { Carbon, } \\
\text { organic, } \\
\text { dis- } \\
\text { solved } \\
\text { (mg/L) }\end{array}$ & $\begin{array}{l}\text { Nitrogen } \\
\text { nitrate, } \\
\text { dissolved } \\
\text { (ms/L } \\
\text { as } N \text { ) }\end{array}$ \\
\hline \multicolumn{12}{|l|}{ MAY } \\
\hline $\begin{array}{l}02 \\
02 \\
02 \\
02 \\
02 \\
02 \\
02 \\
02 \\
02 \\
02\end{array}$ & $\begin{array}{r}3.7 \\
-- \\
-- \\
-- \\
-- \\
3.4 \\
3.4 \\
-- \\
-- \\
2.2\end{array}$ & $\begin{array}{l}0.07 \\
-- \\
-- \\
-- \\
-- \\
.07 \\
.06 \\
-- \\
.07\end{array}$ & $\begin{array}{l}0.02 \\
-- \\
-- \\
-- \\
-- \\
.02 \\
.02 \\
-- \\
.- \\
.02\end{array}$ & $\begin{array}{r}3.2 \\
-- \\
-- \\
-- \\
-- \\
3.8 \\
2.9 \\
-- \\
-- \\
3.0\end{array}$ & $\begin{array}{l}0.03 \\
-- \\
-- \\
-- \\
-- \\
.041 \\
.040 \\
-- \\
-- \\
.021\end{array}$ & $\begin{array}{l}0.004 \\
-- \\
-- \\
-- \\
-- \\
.001 \\
.003 \\
-- \\
-- \\
.002\end{array}$ & $\begin{array}{c}40 \\
-- \\
-- \\
-- \\
-- \\
30 \\
50 \\
-- \\
-- \\
100\end{array}$ & $\begin{array}{c}4 \\
--- \\
-- \\
-- \\
-- \\
0 \\
3 \\
-- \\
-- \\
4\end{array}$ & $\begin{array}{l}17 \\
-- \\
-- \\
-- \\
18 \\
18 \\
-- \\
--\end{array}$ & $\begin{array}{r}2.8 \\
-- \\
-- \\
-- \\
-- \\
2.0 \\
2.4 \\
-- \\
-- \\
2.2\end{array}$ & $\begin{array}{l}0.81 \\
-- \\
-- \\
-- \\
-- \\
.78 \\
.77 \\
-- \\
-- \\
.88\end{array}$ \\
\hline $\begin{array}{l}03 \\
03 \\
03 \\
03 \\
03 \\
03 \\
03 \\
03 \\
03 \\
03 \\
03 \\
03\end{array}$ & $\begin{array}{r}-- \\
-- \\
1.8 \\
-- \\
1.7 \\
1.6 \\
--7 \\
1.7 \\
--7 \\
1.7 \\
-- \\
--\end{array}$ & $\begin{array}{l}-- \\
-- \\
.08 \\
-- \\
.08 \\
.07 \\
-- \\
.07 \\
-- \\
.07 \\
-- \\
--\end{array}$ & $\begin{array}{l}-- \\
-- \\
.02 \\
-- \\
.02 \\
.02 \\
-- \\
.02 \\
-- \\
.02 \\
-- \\
--\end{array}$ & $\begin{array}{r}-- \\
-- \\
2.6 \\
--5 \\
3.4 \\
2.3 \\
--5 \\
3.5 \\
--7 \\
3.7 \\
-- \\
--\end{array}$ & $\begin{array}{l}-- \\
-. \\
.015 \\
-- \\
.012 \\
.15 \\
-. \\
.012 \\
-0 \\
.016 \\
-- \\
--\end{array}$ & $\begin{array}{l}-- \\
-- \\
.004 \\
-- \\
.003 \\
.003 \\
-- \\
.003 \\
-- \\
.003 \\
-- \\
--\end{array}$ & $\begin{array}{r}-- \\
-- \\
190 \\
-- \\
240 \\
270 \\
-- \\
180 \\
-- \\
220 \\
-- \\
--\end{array}$ & $\begin{array}{r}-- \\
-- \\
6 \\
-- \\
6 \\
7 \\
-- \\
7 \\
-- \\
-3 \\
-- \\
--\end{array}$ & $\begin{array}{r}-- \\
-- \\
67 \\
-- \\
110 \\
75 \\
-- \\
100 \\
-- \\
89 \\
-- \\
--\end{array}$ & $\begin{array}{r}-- \\
-- \\
3.3 \\
-- \\
3.8 \\
3.4 \\
-- \\
-- \\
-- \\
-- \\
-- \\
--\end{array}$ & $\begin{array}{l}-- \\
-- \\
.71 \\
-- \\
.74 \\
.74 \\
-- \\
.77 \\
-- \\
.80 \\
-- \\
--\end{array}$ \\
\hline 04 & 1.9 & .06 & .02 & 3.1 & .014 & .003 & 140 & 2 & 52 & $=-$ & .80 \\
\hline
\end{tabular}


Table 15.--Water-quality data for rainfall and snowmelt runoff at Horth Fork Bens Creek at North Fork Reservoir, 1984-86--Continued

$\left[\mathrm{m}^{3} / \mathrm{s}\right.$, cubic meters per second; $\mu \mathrm{S} / \mathrm{cm}$, microsiemens per centimeter at

25 degrees Celsius; mg/h, milligrams per liter; $\mu \mathrm{g} / \mathrm{L}$, micrograms per

liter; <, less than; -- Indicates no data]

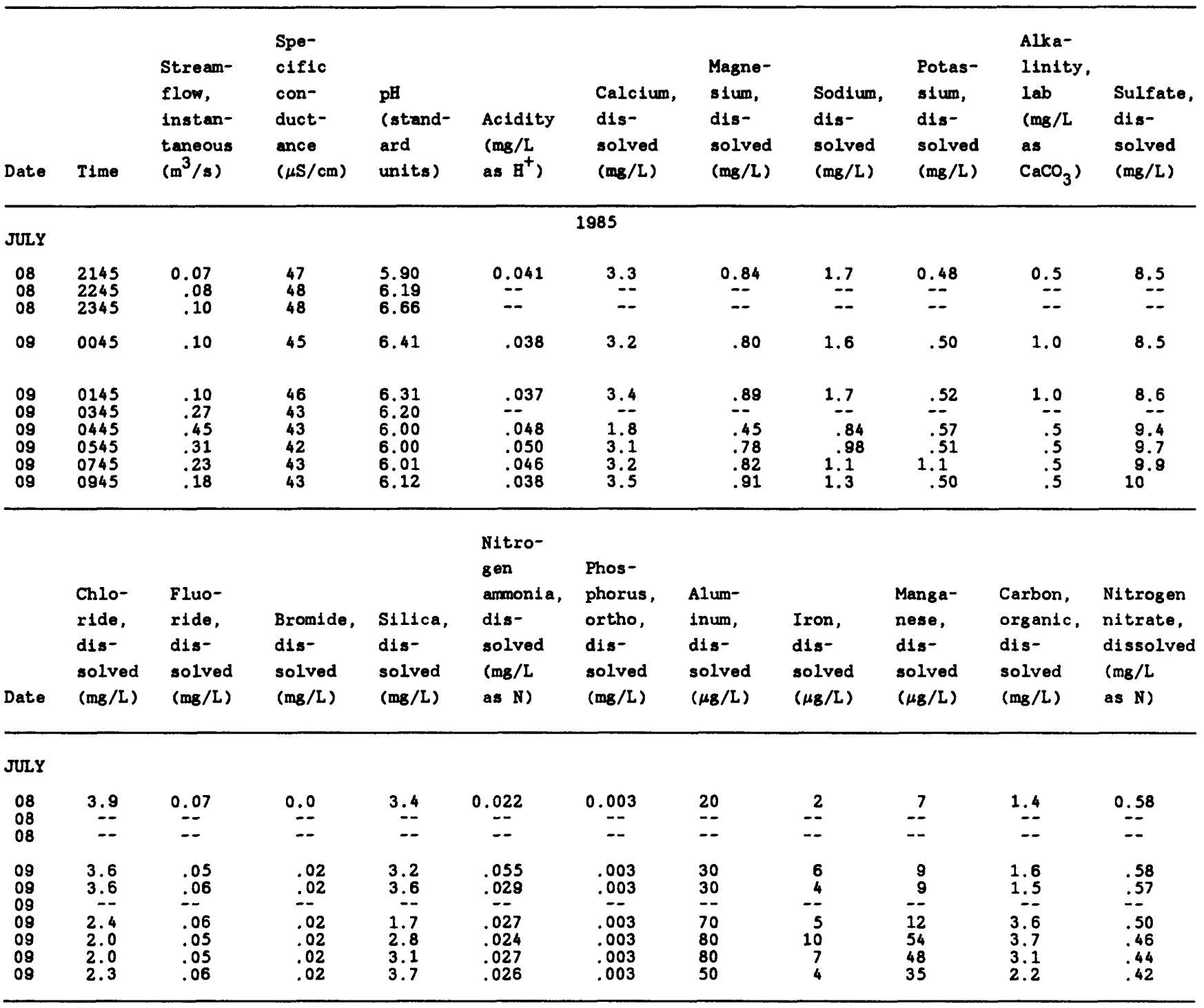


Table 15.--Water-quality data for rainfall and snommelt runoff at North Fork Bens Creek at North Fork Reservoir, 1984-86--Continued

$\left[\mathrm{m}^{3} / \mathrm{s}\right.$, cubic meters per second; $\mu \mathrm{S} / \mathrm{cm}$, microsiemens per centimeter at 25 degrees Celsius; mg/L, milligrams pef liter; $\mu_{B} / L$, micrograms per liter; <, less than; --, indidates no data]

\begin{tabular}{|c|c|c|c|c|c|c|c|c|c|c|c|}
\hline Date & Time & $\begin{array}{l}\text { Stream- } \\
\text { flow, } \\
\text { instan- } \\
\text { taneous } \\
\left(\mathrm{m}^{3} / \mathrm{s}\right)\end{array}$ & $\begin{array}{l}\text { Spe- } \\
\text { cific } \\
\text { con- } \\
\text { duct- } \\
\text { ance } \\
(\mu S / \mathrm{cm})\end{array}$ & $\begin{array}{l}\mathrm{pH} \\
\text { (stand- } \\
\text { ard } \\
\text { units) }\end{array}$ & $\begin{array}{l}\text { Acidity } \\
\left(m_{g} / L\right. \\
\left.\text { as } B^{+}\right)\end{array}$ & $\begin{array}{l}\text { Calcium, } \\
\text { dis- } \\
\text { solved } \\
\text { (mg/L) }\end{array}$ & $\begin{array}{l}\text { Magne- } \\
\text { sium, } \\
\text { dis- } \\
\text { solved } \\
\text { (mg/L) }\end{array}$ & $\begin{array}{l}\text { Sodium, } \\
\text { dis- } \\
\text { solved } \\
(\mathrm{mg} / \mathrm{L})\end{array}$ & $\begin{array}{l}\text { Potas- } \\
\text { sium, } \\
\text { dis- } \\
\text { solved } \\
\text { (ms/L) }\end{array}$ & $\begin{array}{l}\text { Alka- } \\
\text { linity, } \\
\text { lab } \\
(\mathrm{mg} / \mathrm{L} \\
\text { as } \\
\left.\mathrm{CaCO}_{3}\right)\end{array}$ & $\begin{array}{l}\text { Sulfate, } \\
\text { dis- } \\
\text { solved } \\
(\mathrm{mg} / \mathrm{L})\end{array}$ \\
\hline Nov & & & & & & 985 & & & & & \\
\hline $\begin{array}{l}26 \\
26 \\
26 \\
26 \\
26\end{array}$ & $\begin{array}{l}1200 \\
1330 \\
1800 \\
2100 \\
2400\end{array}$ & $\begin{array}{r}0.24 \\
.31 \\
.99 \\
1.12 \\
1.03\end{array}$ & $\begin{array}{l}43 \\
47 \\
42 \\
44 \\
44\end{array}$ & $\begin{array}{l}5.72 \\
5.71 \\
5.40 \\
5.23 \\
5.12\end{array}$ & $\begin{array}{c}0.038 \\
.043 \\
.067 \\
.076 \\
--\end{array}$ & $\begin{array}{l}2.5 \\
2.8 \\
2.7 \\
2.7 \\
=-\end{array}$ & $\begin{array}{r}0.80 \\
.90 \\
.80 \\
.80 \\
--\end{array}$ & $\begin{array}{l}1.1 \\
1.2 \\
.800 \\
.80 \\
=-\end{array}$ & $\begin{array}{r}0.54 \\
.53 \\
.51 \\
.54 \\
.-\end{array}$ & $\begin{array}{r}<0.5 \\
<.5 \\
<.5 \\
<.5 \\
=-\end{array}$ & $\begin{array}{l}9.5 \\
9.7 \\
13 \\
11 \\
\end{array}$ \\
\hline $\begin{array}{l}27 \\
27 \\
27\end{array}$ & $\begin{array}{l}0200 \\
0800 \\
1500\end{array}$ & $\begin{array}{l}.98 \\
.87 \\
.83\end{array}$ & $\begin{array}{l}45 \\
42 \\
41\end{array}$ & $\begin{array}{l}5.18 \\
5.20 \\
5.23\end{array}$ & $\begin{array}{l}.072 \\
.055 \\
.058\end{array}$ & $\begin{array}{l}2.6 \\
2.5 \\
2.8\end{array}$ & $\begin{array}{l}.80 \\
.80 \\
.90\end{array}$ & $\begin{array}{l}.80 \\
.80 \\
.90\end{array}$ & $\begin{array}{r}.53 \\
.56 \\
.51\end{array}$ & $\begin{array}{l}<.5 \\
<.5 \\
<.5\end{array}$ & $\begin{array}{l}12 \\
11 \\
11\end{array}$ \\
\hline $\begin{array}{l}28 \\
28 \\
28 \\
28\end{array}$ & $\begin{array}{l}0400 \\
0800 \\
1200 \\
2000\end{array}$ & $\begin{array}{l}1.30 \\
1.67 \\
2.02 \\
1.85\end{array}$ & $\begin{array}{l}41 \\
49 \\
4.3 \\
4.3\end{array}$ & $\begin{array}{l}5.15 \\
5.07 \\
4.99 \\
5.04\end{array}$ & $\begin{array}{c}<.060 \\
-- \\
-0 \\
.067\end{array}$ & $\begin{array}{r}2.7 \\
-- \\
-- \\
2.7\end{array}$ & $\begin{array}{l}.80 \\
-- \\
-8 \\
.80\end{array}$ & $\begin{array}{l}.80 \\
-- \\
-- \\
.80\end{array}$ & $\begin{array}{l}.54 \\
-- \\
-5 \\
.53\end{array}$ & $\begin{array}{r}<.5 \\
--- \\
<.5\end{array}$ & $11^{--}$ \\
\hline \multicolumn{12}{|l|}{ DEC } \\
\hline 04 & 1015 & .25 & 45 & 5.49 & -- & -- & -- & -- & -- & -- & -- \\
\hline Date & $\begin{array}{l}\text { Chlo- } \\
\text { ride, } \\
\text { dis- } \\
\text { solved } \\
\text { (mg/L) }\end{array}$ & $\begin{array}{l}\text { Fluo- } \\
\text { ride, } \\
\text { dis- } \\
\text { solved } \\
\text { (mg/L) }\end{array}$ & $\begin{array}{l}\text { Bromide } \\
\text { dis- } \\
\text { solved } \\
\text { (mg/L) }\end{array}$ & $\begin{array}{l}\text { Silica, } \\
\text { dis- } \\
\text { solved } \\
(\mathrm{mg} / \mathrm{L})\end{array}$ & $\begin{array}{l}\text { Nitro- } \\
\text { gen } \\
\text { ammonia, } \\
\text { dis- } \\
\text { solved } \\
\text { (mg/L } \\
\text { as } N \text { ) }\end{array}$ & $\begin{array}{l}\text { Phos- } \\
\text { phorus, } \\
\text { ortho, } \\
\text { dis- } \\
\text { solved } \\
\text { (mg/L) }\end{array}$ & $\begin{array}{l}\text { Alum- } \\
\text { inum, } \\
\text { dis- } \\
\text { solved } \\
(\mu g / L)\end{array}$ & $\begin{array}{l}\text { Iron, } \\
\text { dis- } \\
\text { solved } \\
(\mu g / L)\end{array}$ & $\begin{array}{l}\text { Manga- } \\
\text { nese, } \\
\text { dis- } \\
\text { solved } \\
(\mu g / L)\end{array}$ & $\begin{array}{l}\text { Carbon, } \\
\text { organic, } \\
\text { dis- } \\
\text { solved } \\
\text { (mg/L) }\end{array}$ & $\begin{array}{l}\text { Nitrogen } \\
\text { nitrate, } \\
\text { dissolved } \\
\text { (mg/L } \\
\text { as N) }\end{array}$ \\
\hline \multicolumn{12}{|l|}{ NOV } \\
\hline $\begin{array}{l}26 \\
26 \\
26 \\
26 \\
26\end{array}$ & $\begin{array}{r}2.9 \\
2.8 \\
1.9 \\
1.8 \\
--\end{array}$ & $\begin{array}{l}0.06 \\
.06 \\
.07 \\
.08 \\
.-\end{array}$ & $\begin{array}{l}0.02 \\
.02 \\
.02 \\
.02 \\
.-\end{array}$ & $\begin{array}{l}3.1 \\
3.4 \\
3.1 \\
3.0 \\
=-\end{array}$ & $\begin{array}{l}0.034 \\
.020 \\
.81 \\
.045 \\
=-\end{array}$ & $\begin{array}{l}0.001 \\
<.001 \\
.001 \\
<.001 \\
--\end{array}$ & $\begin{array}{r}60 \\
77 \\
180 \\
240 \\
---\end{array}$ & $\begin{array}{r}2.7 \\
3.7 \\
9.8 \\
13 \\
--\end{array}$ & $\begin{array}{l}26 \\
35 \\
68 \\
86 \\
--\end{array}$ & $\begin{array}{l}1.4 \\
1.5 \\
3.3 \\
3.5 \\
---\end{array}$ & $\begin{array}{r}0.69 \\
.62 \\
.40 \\
.35 \\
-\end{array}$ \\
\hline $\begin{array}{l}27 \\
27 \\
27\end{array}$ & $\begin{array}{l}1.9 \\
1.9 \\
2.0\end{array}$ & $\begin{array}{l}.08 \\
.08 \\
.08\end{array}$ & $\begin{array}{l}.02 \\
.02 \\
.02\end{array}$ & $\begin{array}{l}3.0 \\
3.1 \\
3.4\end{array}$ & $\begin{array}{l}.015 \\
.013 \\
.019\end{array}$ & $\begin{array}{l}<.001 \\
<.001 \\
<.001\end{array}$ & $\begin{array}{l}230 \\
17 \\
150\end{array}$ & $\begin{array}{r}10 \\
5.7 \\
2.1\end{array}$ & $\begin{array}{l}84 \\
62 \\
62\end{array}$ & $\begin{array}{r}2.8 \\
3.2 \\
--\end{array}$ & $\begin{array}{l}.42 \\
.53 \\
.61\end{array}$ \\
\hline $\begin{array}{l}28 \\
28 \\
28 \\
28\end{array}$ & $\begin{array}{r}1.8 \\
-- \\
-- \\
1.7\end{array}$ & $\begin{array}{l}.08 \\
-- \\
.08\end{array}$ & $\begin{array}{l}.02 \\
-- \\
.02\end{array}$ & $\begin{array}{r}3.3 \\
-- \\
-- \\
3.2\end{array}$ & $\begin{array}{l}.019 \\
=- \\
.035\end{array}$ & $\begin{array}{c}<.001 \\
-- \\
-\overline{-001}\end{array}$ & $\begin{array}{c}200 \\
-- \\
-\overline{-} \\
220\end{array}$ & $\begin{array}{r}4.4 \\
-.- \\
3.2\end{array}$ & $\begin{array}{l}79 \\
-- \\
-- \\
88\end{array}$ & $\begin{array}{l}=- \\
=- \\
=-\end{array}$ & $\begin{array}{l}.49 \\
-- \\
.5 \\
.59\end{array}$ \\
\hline $\begin{array}{r}\text { DEC } \\
04\end{array}$ & -- & -- & -- & -- & -- & -- & -- & $=$ & -- & -- & -- \\
\hline
\end{tabular}


Table 15.--Water-quality data for rainfall and snownelt runoff at North Fork Bens Creek at North Fork Reservoir, 1984-86--Continued

$\left[\mathrm{m}^{3} / \mathrm{s}\right.$, cubic meters per second; $\mu \mathrm{S} / \mathrm{cm}$, microsiemens per centimeter at 25 degrees Celsius; mg/L, milligrams per liter; $\mu 8 / L$, micrograms per liter; <, less than; --, indicates no data]

\begin{tabular}{|c|c|c|c|c|c|c|c|c|c|c|c|}
\hline Date & Time & $\begin{array}{l}\text { Stream- } \\
\text { flow, } \\
\text { instan- } \\
\text { taneous } \\
\left(\mathrm{m}^{3} / \mathrm{s}\right)\end{array}$ & $\begin{array}{l}\text { Spe- } \\
\text { cific } \\
\text { con- } \\
\text { duct- } \\
\text { ance } \\
(\mu S / \mathrm{cm})\end{array}$ & $\begin{array}{l}\text { pH } \\
\text { (stand- } \\
\text { ard } \\
\text { units) }\end{array}$ & $\begin{array}{l}\text { Acidity } \\
\text { (mg/L } \\
\text { as } \mathrm{H}^{+} \text {) }\end{array}$ & $\begin{array}{l}\text { Calcium, } \\
\text { dis- } \\
\text { solved } \\
(\mathrm{mg} / \mathrm{L})\end{array}$ & $\begin{array}{l}\text { Magne- } \\
\text { sium, } \\
\text { dis- } \\
\text { solved } \\
\text { (mg/L) }\end{array}$ & $\begin{array}{l}\text { Sodium, } \\
\text { dis- } \\
\text { solved } \\
\text { (mg/L) }\end{array}$ & $\begin{array}{l}\text { Potas- } \\
\text { sium, } \\
\text { dis- } \\
\text { solved } \\
\text { (mg/L) }\end{array}$ & $\begin{array}{l}\text { Alka- } \\
\text { linity, } \\
\text { lab } \\
(\mathrm{mg} / \mathrm{L} \\
\text { as } \\
\left.\mathrm{CaCO}_{3}\right)\end{array}$ & $\begin{array}{l}\text { Sulfate, } \\
\text { dis- } \\
\text { solved } \\
(\mathrm{mg} / \mathrm{L})\end{array}$ \\
\hline \multicolumn{12}{|c|}{1986} \\
\hline $\begin{array}{l}04 \\
04 \\
04 \\
04 \\
04\end{array}$ & $\begin{array}{l}1130 \\
1430 \\
1730 \\
2030 \\
2330\end{array}$ & $\begin{array}{r}0.28 \\
.46 \\
1.04 \\
.90 \\
.78\end{array}$ & $\begin{array}{l}40 \\
41 \\
40 \\
40 \\
40\end{array}$ & $\begin{array}{l}5.5 \\
5.41 \\
5.28 \\
5.20 \\
5.2\end{array}$ & $\begin{array}{l}0.019 \\
-- \\
-- \\
-- \\
.039\end{array}$ & $\begin{array}{r}2.7 \\
-- \\
-- \\
-- \\
2.7\end{array}$ & $\begin{array}{l}0.90 \\
-- \\
-- \\
-- \\
.80\end{array}$ & $\begin{array}{l}1.0 \\
=- \\
-- \\
-- \\
.80\end{array}$ & $\begin{array}{l}0.52 \\
-- \\
-- \\
-- \\
.53\end{array}$ & $\begin{array}{r}<0.5 \\
-- \\
-- \\
-- \\
<.5\end{array}$ & $\begin{array}{l}10 \\
-- \\
-- \\
-- \\
11\end{array}$ \\
\hline $\begin{array}{l}05 \\
05 \\
05 \\
05 \\
05 \\
05\end{array}$ & $\begin{array}{l}0330 \\
0530 \\
0730 \\
0930 \\
1430 \\
1730\end{array}$ & $\begin{array}{l}.84 \\
1.61 \\
2.37 \\
2.51 \\
2.42 \\
2.49\end{array}$ & $\begin{array}{l}42 \\
41 \\
42 \\
44 \\
45 \\
44\end{array}$ & $\begin{array}{l}5.20 \\
5.18 \\
4.9 \\
4.8 \\
4.8 \\
4.81\end{array}$ & $\begin{array}{l}-- \\
-. \\
.055 \\
.056 \\
.055 \\
.-\end{array}$ & $\begin{array}{r}-- \\
-- \\
2.9 \\
2.7 \\
2.5 \\
--\end{array}$ & $\begin{array}{l}-- \\
-- \\
.80 \\
.70 \\
.70 \\
--\end{array}$ & $\begin{array}{l}-- \\
-- \\
.80 \\
.70 \\
.60 \\
--\end{array}$ & $\begin{array}{l}-- \\
-- \\
.59 \\
.61 \\
.63 \\
--\end{array}$ & $\begin{array}{l}-- \\
-- \\
<.5 \\
<.5 \\
<.5 \\
---\end{array}$ & $\begin{array}{l}-- \\
-- \\
11 \\
11 \\
11 \\
--\end{array}$ \\
\hline $\begin{array}{l}06 \\
06\end{array}$ & $\begin{array}{l}0430 \\
2030\end{array}$ & $\begin{array}{l}1.96 \\
1.47\end{array}$ & $\begin{array}{l}44 \\
42\end{array}$ & $\begin{array}{l}4.88 \\
5.10\end{array}$ & $\begin{array}{l}.046 \\
.055\end{array}$ & $\begin{array}{l}2.7 \\
2.5\end{array}$ & $\begin{array}{l}.80 \\
.70\end{array}$ & $\begin{array}{l}.70 \\
.80\end{array}$ & $\begin{array}{l}.67 \\
.55\end{array}$ & $\begin{array}{l}<.5 \\
<.5\end{array}$ & $\begin{array}{l}11 \\
10\end{array}$ \\
\hline $\begin{array}{l}07 \\
07\end{array}$ & $\begin{array}{l}0730 \\
1930\end{array}$ & $\begin{array}{r}1.03 \\
.82\end{array}$ & $\begin{array}{l}44 \\
44\end{array}$ & $\begin{array}{l}5.02 \\
5.01\end{array}$ & $\begin{array}{l}.032 \\
.028\end{array}$ & $\begin{array}{l}2.6 \\
2.7\end{array}$ & $\begin{array}{l}.80 \\
.80\end{array}$ & $\begin{array}{l}1.0 \\
1.1\end{array}$ & $\begin{array}{l}.58 \\
.66\end{array}$ & $\begin{array}{l}<.5 \\
<.5\end{array}$ & $\begin{array}{l}10 \\
10\end{array}$ \\
\hline 08 & 1930 & .46 & 42 & 5.22 & .045 & 2.8 & .80 & 1.2 & .8 & $<.5$ & 10 \\
\hline
\end{tabular}

\begin{tabular}{|c|c|c|c|c|c|c|c|c|c|c|c|}
\hline Date & $\begin{array}{l}\text { Chlo- } \\
\text { ride, } \\
\text { dis- } \\
\text { solved } \\
\text { (mg/L) }\end{array}$ & $\begin{array}{l}\text { Fluo- } \\
\text { ride, } \\
\text { dis- } \\
\text { solved } \\
\text { (mg/L) }\end{array}$ & $\begin{array}{l}\text { Bromide, } \\
\text { dis- } \\
\text { solved } \\
\text { (mg/L) }\end{array}$ & $\begin{array}{l}\text { Sillca, } \\
\text { dis- } \\
\text { solved } \\
(\mathrm{mg} / \mathrm{L})\end{array}$ & $\begin{array}{l}\text { Nitro- } \\
\text { gen } \\
\text { ammonia, } \\
\text { dis- } \\
\text { solved } \\
\text { (mg/L } \\
\text { as } N \text { ) }\end{array}$ & $\begin{array}{l}\text { Phos- } \\
\text { phorus, } \\
\text { ortho, } \\
\text { dis- } \\
\text { solved } \\
\text { (mg/L) }\end{array}$ & $\begin{array}{l}\text { Alum- } \\
\text { inum, } \\
\text { dis- } \\
\text { solved } \\
(\mu g / L)\end{array}$ & $\begin{array}{l}\text { Iron, } \\
\text { dis- } \\
\text { solved } \\
(\mu 8 / L)\end{array}$ & $\begin{array}{l}\text { Manga- } \\
\text { nese, } \\
\text { dis- } \\
\text { solved } \\
(\mu 8 / L)\end{array}$ & $\begin{array}{l}\text { Carbon, } \\
\text { organic, } \\
\text { dis- } \\
\text { solved } \\
\text { (mg/L) }\end{array}$ & $\begin{array}{l}\text { Nitrogen } \\
\text { nitrate, } \\
\text { dissolved } \\
\text { (mg/L } \\
\text { as N) }\end{array}$ \\
\hline \multicolumn{12}{|l|}{ FEB } \\
\hline $\begin{array}{l}04 \\
04 \\
04 \\
04 \\
04\end{array}$ & $\begin{array}{r}2.2 \\
-- \\
-- \\
-- \\
1.7\end{array}$ & $\begin{array}{l}0.07 \\
-- \\
-- \\
.07\end{array}$ & $\begin{array}{l}0.02 \\
-- \\
-- \\
.02\end{array}$ & $\begin{array}{r}3.0 \\
-- \\
-- \\
-- \\
2.7\end{array}$ & $\begin{array}{l}0.019 \\
-- \\
-- \\
-- \\
.014\end{array}$ & $\begin{array}{c}<0.001 \\
-- \\
-- \\
-- \\
<.001\end{array}$ & $\begin{array}{r}91 \\
-- \\
-- \\
-- \\
230\end{array}$ & $\begin{array}{l}<2 \\
-- \\
-- \\
-- \\
<2\end{array}$ & $\begin{array}{l}39 \\
-- \\
-- \\
-- \\
81\end{array}$ & $\begin{array}{r}2.4 \\
-- \\
-- \\
2.7\end{array}$ & $\begin{array}{l}0.67 \\
-- \\
-- \\
- \\
.66\end{array}$ \\
\hline $\begin{array}{l}05 \\
05 \\
05 \\
05\end{array}$ & $\begin{array}{r}1.4 \\
1.3 \\
1.3 \\
--\end{array}$ & $\begin{array}{l}.09 \\
.08 \\
.08 \\
--\end{array}$ & $\begin{array}{l}.02 \\
.02 \\
.02 \\
--\end{array}$ & $\begin{array}{r}2.8 \\
2.4 \\
2.4 \\
-\end{array}$ & $\begin{array}{l}.007 \\
.014 \\
.013 \\
--\end{array}$ & $\begin{array}{l}.002 \\
.003 \\
.001 \\
--\end{array}$ & $\begin{array}{r}310 \\
310 \\
260 \\
-\end{array}$ & $\begin{array}{r}2.3 \\
<.2 \\
<2 \\
--\end{array}$ & $\begin{array}{r}140 \\
150 \\
120 \\
--\end{array}$ & $\begin{array}{r}4.6 \\
3.3 \\
2.5 \\
-.-\end{array}$ & $\begin{array}{l}.64 \\
.67 \\
.72 \\
.-\end{array}$ \\
\hline $\begin{array}{l}06 \\
06\end{array}$ & $\begin{array}{l}1.5 \\
1.9\end{array}$ & $\begin{array}{l}.08 \\
.07\end{array}$ & $\begin{array}{l}.03 \\
.03\end{array}$ & $\begin{array}{l}3.0 \\
2.9\end{array}$ & $\begin{array}{l}.016 \\
.011\end{array}$ & $\begin{array}{l}.002 \\
.002\end{array}$ & $\begin{array}{l}270 \\
140\end{array}$ & $\begin{array}{l}<2 \\
10\end{array}$ & $\begin{array}{r}100 \\
69\end{array}$ & $\begin{array}{l}2.6 \\
1.6\end{array}$ & $\begin{array}{r}.73 \\
.75\end{array}$ \\
\hline $\begin{array}{l}07 \\
07\end{array}$ & $\begin{array}{l}2.1 \\
2.3\end{array}$ & $\begin{array}{l}.06 \\
.06\end{array}$ & $\begin{array}{l}.03 \\
.03\end{array}$ & $\begin{array}{l}3.1 \\
3.2\end{array}$ & $\begin{array}{l}.034 \\
.025\end{array}$ & $\begin{array}{l}.002 \\
.002\end{array}$ & $\begin{array}{l}140 \\
130\end{array}$ & $\begin{array}{l}<2 \\
<2\end{array}$ & $\begin{array}{l}69 \\
63\end{array}$ & $\begin{array}{l}1.2 \\
1.2\end{array}$ & $\begin{array}{l}.78 \\
.79\end{array}$ \\
\hline 08 & 2.7 & .06 & .03 & 3.3 & .050 & .001 & 100 & $<2$ & 50 & 1.3 & .80 \\
\hline
\end{tabular}


The potential for acidic runoff to alter stream chemistry is influenced by such factors as season, magnitude and duration of rainfal1, weather pattern, and the degree of saturation of the unconsolidated zone. Most interactions between runoff and the watershed can be attributed to various cation-exchange processes within the soil horizons. Consequently, passage of the runoff through the layers of the unconsolidated zone will affect the quality of the stream.

The sensitivity of watershed soils to leaching by sulfuric and nitric acid has been shown to be site speciflc. For example, Johnson and others (1982) stated that soils sensitive to leaching by sulfuric acid generally are those low in iron, aluminum oxides, and clay but high in organic matter and $\mathrm{pH}$, whereas soils sensitive to nitric-acid leaching generally are those with an abundance of nitrogen. This generalization contradicts the finding in the North Fork and South Fork Bens Creek watersheds where the unconsolidated zones characteristically have low $\mathrm{pH}$, large cation-exchange capacities, and a mix of highly weathered sandstone and organic matter within the upper horizon of the mineral soil layer. Both watersheds are sensitive to leaching by sulfuric acid, especially during large storms of long duration. Excess nitrate leaves the watershed during snowmelt runoff, indicating possible nitric acid leaching during the nongrowing season.

Chemical recovery of stormflow and snowmelt events is highly variable. Stream chemistry for stormflow events generally recovers to pre-event conditions in conjunction with the hydrograph. Stream-chemistry recovery following snowmelt-runoff events may require as much as a week after discharge recovery. The pre- and post-event mechanisms for the passage of acid precipitation through the North Fork Bens Creek and South Fork Bens Creek watersheds are described in a general way, by attempting to follow the input water through the canopy, detrital layer, and soil layers.

The layers of the unconsolidated soil zone having the greatest influence on stream chemistry during runoff events are the detrital and mineral soil layer. The detrital layer is a potential source of both acids and bases through decomposition and root-respiration. Contribution to and growth within the detrital layer will control whether the pre-precipitation conditions will be either acidic or basic. Also, byproducts of microbial action can be significant factors in cation exchange as they become available to the mineral soil layer by percolation from the detrital layer. Generally, the reactions that occur within the detrital layer at the beginning of runoff events are short lived and only alter stream chemistry when there have been several days between events. Most water that percolates through the detrital layer will pass through the mineral soil layer before entering the stream; water initially buffered by the detrital layer would quickly be reacidified after the buffering components of the mineral soil layer are neutralized.

The mineral soil layer plays host to most of the cation exchange that occurs within the watershed. Mineral soils in both the North Fork and South Fork Bens Creek basins are very stony silt loams and are characteristically acid, well drained, and moderately deep. As with the detrital layer, the hydrogen-ion concentration within the soils can be increased or decreased by 
various processes. For example, the mineralization and oxidation of sulfur, nitrogen, and phosphorus from the forest floor (percolation from the detrital layer) results in the formation of acids (sulfuric, nitric, and phosphoric), whereas mineralization of potassium, calcium, magnesium, and manganese leads to the production of bases (Johnson and others, 1982). The combination of carbon dioxide released by decomposition and root respiration with water to form carbonic acid has been shown to be another major natural source of hydrogen ions in many forest soils (McColl and Cole, 1968; Johnson and others, 1977; Andersson and others, 1980). Before precipitation occurs, all of the above processes in the soil are a continuous process. These processes are extremely complex and can vary seasonally and even temporally. As a result, it is unlikely that these processes will ever be quantified. It is known, however, that the watershed soils contain significantly more potassium, calcium, magnesium, and manganese than nitrogen and phosphorus; therefore, an accumulation of buffers would most likely occur. The demineralization of these base complexes, in addition to the formation of aluminum salts during initial runoff, temporarily increases the $\mathrm{pH}$. Mineral soils essentially are acid in the deeper zones; therefore, demineralization of the base complexes formed near the surface of the soil layer would occur rapidly, and, depending on the sampling frequency, increases in $\mathrm{pH}$ in streamflow during the first stormflow discharges may not be observed.

\section{During Input of First 20 Percent of Constituents in Acidic Precipitation}

The first 20 percent or so of acid precipitation entering the watershed is responsible for the neutralization reactions of all accumulated buffering components from the pre-event period. During the growing season the forest canopy would provide one medium for buffering precipitation $\mathrm{pH}$. For example, Johnson and others (1982) noted a study in Sweden wherein a beech-maple type forest, for which average annual $\mathrm{pH}$ values for rainfall and throughfall were 5.2 and 5.7, respectively, indicated that the deciduous canopy can raise pH. The precipitation leaving the canopy would encounter the detrital and mineral soil layers where demineralization of the pre-precipitation base complexes would occur. The resulting flush of this buffered precipitation solution along with the "pooled" buffered solution from previous events, increases the $\mathrm{pH}$. Plots of discharge as a function of $\mathrm{pH}$ in figures 19-B, G, H, I, and $\mathrm{J}$, show this phenomenon. Also at this stage in the flow-thru, there is a steady increase of dissolved cations that enter streamflow independent of the decrease in hydrogen ions. This independence is possibly the result of a reserve of dissolved cations in soil solutions from the deeper more acidic part of the unconsolidated zone. The $\mathrm{pH}$ range for soils of the Hazleton, Ernest, and Rayne-Gilpin loams is from 4.5 to 5.5 (U.S. Department of Agriculture, 1983). Under these conditions, natural leaching could occur, making dissolved cations available for flushing. Hewlett and Hibbert (1967) contend that the upper horizons of the soils contain readily soluble materials, and any soil water, flushed by the overland runoff and shunted to the stream by throughflow mechanisms, will be highly charged with solutes. 
During Input of 50 Percent of Constituents in Acidic Precipitation

As acid deposition continues, half of the total input of constituents in the acid deposition would be interacting with the system. The preprecipitation buffers accumulating in the forest canopy and unconsolidated zone would be completely used by the first 20 percent of the event input. Minor acidification by plant respiration and carbonic acid formation would occur within the canopy. Combined with the acidic rainfall, the system would begin to show stress because of acidification. Dissolved metals mobilized in the detrital layer percolate into the mineral soil layer where they are maintained in solution by the natural acidic conditions. Additional concentrations of hydrogen ions within the mineral soil layer cause further cation exchange and dissolved-metal mobilization. Stream chemistry at this point shows a sharp increase in dissolved metals, a decrease in base cations, and an increase in sulfate as a result of increased drainage from the mineral soil layer.

\section{After Input of 100 Percent of Constituents in Acidic Precipitation}

At the conclusion of rainfall or snowmelt input, stream discharge would be near its maximum and the watershed system would be acidic throughout the unconsolidated zone. Runoff at this point generally contains peak concentrations of total dissolved aluminum and dissolved manganese, sulfate, and, during snowmelt runoff, nitrate. Calcium concentration increased and then decreased during runoff events; therefore, no trend was detected. Aluminum had the greatest increase throughout all events. Dissolved aluminum has been shown to be toxic to trout populations at concentration above 200 $\mu \mathrm{g} / \mathrm{L}$ (Cronan and Schoefield, 1979). Dissolved-aluminum concentrations reached potentially toxic levels for 43 percent of the events sampled on the North Fork Bens Creek; snowmelt runoff events comprise half of the events with toxic levels. The dissolved-aluminum concentrations in South Fork Bens Creek never reached toxic levels during any sampled events; however, large fish kills were reported in the adjoining fish nursery during the snowmelt runoff events of 1984 and 1985.

The mobilization of dissolved aluminum and other constituents is greatest in the mineral soil horizon of the unconsolidated zone. Sharpe and others (1984) have shown that, during four major precipitation events on Laurel Hill, the mineral soil horizon produced leachate with $\mathrm{pH}$ greater than the $\mathrm{pH}$ of water passing through the detrital layer; the concentration of hydrogen ions decreased 72 percent and concentrations of dissolved calcium, magnesium, sulfate, nitrate, chloride, and aluminum increased. All increases were statistically significant, except for calcium. These results, from samples collected using zero-tension pan lysimeters installed in soil pits, do not reflect what actually entered the stream. Sharpe's lysimeter data, however, do indicate most interaction with hydrogen ions is occurring within the mineral soil layer and that this layer is the primary source of dissolved aluminum. Mineral soils of the North Fork Bens Creek and South Fork Bens Creek are similar in chemistry to the Dekalb and Calvin soils of the Sharpe study; therefore, the interactions should be somewhat similar. 
The amount of precipitation measured at South Fork Bens Creek in the 1984 and 1985 water years was $1,482.1$ and $1,051.8 \mathrm{~mm}$, respectively, and $1,015.7 \mathrm{~mm}$ at North Fork in the 1985 water year. Average precipitation for this region is about $1,350 \mathrm{~mm}$ annua11y. The minimum and maximum $\mathrm{pH}$ measured in precipitation during the 1984-85 water years was 3.59 and 4.85, respectively. The volume-weighted average was 4.06. Precipitation was, on the average, about 35 times more acidic than "pure rain". Precipitation was slightly more acidic during the growing season than during the dormant season. These values are in close agreement with those of other investigators working in southwestern Pennsylvania.

Hydrogen, sulfate, and nitrate are the dominant ions in precipitation. Sulfate is the dominant precursor for acid formation in precipitation and in both watersheds. Nitrate is substantially more abundant than sulfate in snowfall and contributes to streamflow acidification only during snowmelt.

Annual chemical constituent budgets for both watersheds show net losses for base cations, sulfate, and chloride--net accumulation was observed for nitrate and hydrogen ion. The net flux for nitrate shows that about 46 percent was retained in the South Fork and about 50 percent was retained in the North Fork ecosystems. Accumulation of hydrogen ion in both South Fork and North Fork Bens Creek basins was 99 and 74 percent, respectively.

Streamflow chemistry responds to acidic storm runoff with increases in dissolved metals and sulfate concentrations, and decreases in nitrate, base cations, and silica concentrations. Dissolved-aluminum concentrations reached levels potentially toxic to fish in four of the five streams at least once during the 2 1/2-year study period. Pre-precipitation mineralization of manganese, magnesium, potassium, and calcium in the soil horizons appears to be significant in accumulating initial hydrogen influx. Values of $\mathrm{pH}$ have been shown to be independent of mobilized solutes during the beginning of stormflow as a result of "flushing" of dissolved metals from the predominantly acidic unconsolidated zone of both watersheds. At peak storm runoff, streamflow reaches its lowest $\mathrm{pH}$ and highest dissolved-aluminum concentration. 
Andersson, Folke, Fagerstrom Torbjorn, and Nilsson S.I., 1980, Forest ecosystem responses to acid deposition-hydrogen ion budget and nitrogen/tree growth model approaches, in Hutchinson, T.C., and Havas, M., eds., Effects of acid precipitation on terrestrial ecosystems: NATO Conference on Effects of Acid Precipitation on Vegetation and Soils, Toronto, Canada, 1978: New York, Plenum Press, p. 319-334.

Aquatic Effects Task Group, 1985, (revised 3/85). Working protocol for sampling, sample analysis, and $Q A / Q C$ for the USEPA long-term surface water monitoring program: Draft of document, $20 \mathrm{p}$.

Berg, T.M., and Dodge, C.M., 1981, Atlas of preliminary geologic quadrangle maps of Pennsylvania: Pennsylvania Geological Survey, 4th series, $636 \mathrm{p}$.

Bigelow, D.S., 1982, Draft NADP instruction manual/site operation, National Atmospheric Deposition Program, NC-141: Colorado State University, 30 p.

Bowersox, V.C., and DePena, R.G., 1980, Analysis of precipitation chemistry at a central Pennsylvania site: Journal Geophysical Research, v. 85, no. c. 10, p. 5614-5620.

Cronan, C.S. and Schoefield, C.L., 1979, Aluminum leaching response to acid precipitation: Effects on high elevation watersheds in the northeast: Science, v. 204, 306 p.

DeWalle, D.R., Dinicola, R.S., and Sharpe, W.E., 1987, Predicting base flow alkalinity as an index to episodic stream acidification and fish presence: Water Resources Bulletin, v. 23, no. 1, p. 29-35.

DeWalle, D.R., Sharpe, W.E., Dinicola, R.S., Leibfried, R.T., and Kimmel, W.G., 1982, Causes of acidification of four streams on Laurel Hill in southwestern Pennsylvania, Institute for research on land and water resources, the Pennsylvania State University, $62 \mathrm{p}$.

DeWa1le, D.R., Sharpe, W.E., Izbicki, J.A., and Wirries, D.L., 1983, Acid snowpack chemistry in Pennsylvania, 1979-81: Water Resources Bulletin, v. 19, no. 6, p. 993-1001.

Edwards, A.M.C., 1973, The variations of dissolved constituents with discharge in some Norfolk rivers: Journal of Hydrology, v. 18, p. 219-242.

Flint, N.K., 1965, Geology and mineral resources of southern Somerset County, Pennsylvania: Commonwealth of Pennsylvania Department of Environmental Resources, Bureau of Topographic and Geologic Survey, County Report, 56A, $267 \mathrm{p}$.

Galloway, J.N., and Likens, G.E., 1981, Acid precipitation: The importance of nitric acid: Atmospheric Environment, v. 15, no. 6, p. 1081-1085. 


\section{REFERENCES CITED--Continued}

Galloway, J.N., Schofield, C.L., Peters, N.E., Hendrey, G.R., and Altwicker, E.R., 1983, Effects of atmospheric sulfur on the composition of three Adirondack lakes: Canadian Journal of Fisheries and Aquatic Sciences, v. 40, no. 6 , p. 799-806.

Hewlett, J.D. and Hibbert, A.R., 1967, Factors affecting the response of small watersheds to precipitation in humid areas, in W.E. Sopper and H.W. Lull (editors), International Symposium on Forest Hydrology, Pergamon, Oxford, p. $725-736$.

Johnson, D.W., Cole, D.W., Gesse1, S.P., Singer, M.J., and Minden, R.V., 1977, Carbonic Acid leaching in a tropical, temperate, subalpine, and northern forest soil: Arctic Alpine Research, v. 9, p. 329-343.

Johnson, D.W., Turner, J., and Kelly, J.M., 1982, The effects of acid rain on forest nutrient status: Water Resources Research, v. 18, no. 3, p. 449-461.

Katz, B.G., Bricker, O.P., and Kennedy, M.M., 1985, Geochemical mass-balance relationships for selected ions in precipitation and stream water, Catoctin Mountains, Maryland: American Journal of Science, vol. 285, p. 931-962.

Kohler, M.A., Norderson, T.J., and Baker, D.R., 1959, Evaporation maps of the U.S.: Tech. Paper no. 37, Weather Bureau, Dept. of Commerce, Washington, D.C., 13 p., 5 plates.

Likens, G.E., 1976, Acid precipitation: Chemical and Engineering News, v. 54, no. 48, p. 29-37.

McColl, J.G., and Cole, D.W., 1968, A mechanism of cation transport in a forest soil: Northwest Science, v. 42, p. 134-140.

National Acid Precipitation Assessment Program, 1985, Annual report, 1985, $113 \mathrm{p}$.

National Oceanic and Atmospheric Administration, 1950-1985, Climatologic data annual summary: Asheville, N.C., National Climatic Data Center, v. 62-94 (published annually).

Pennsylvania Department of Enviromental Resources, 1982, Pennsylvania perspective on acid rain: PaDER, Harrisburg, Pennsylvania, 31 p.

Pettyjohn, W.A., and Henning, Roger, 1979, Preliminary estimate of groundwater recharge rates, related streamflow and water quality in Ohio: The Ohio State University Department of Geology and Minerology project completion report no. 552, $323 \mathrm{p}$.

Porterfield, George., 1972, Computation of fluvial-sediment discharge: U.S. Geological Survey Techniques of Water-Resources Investigations, book 3, chap. C3, $66 \mathrm{p}$. 


\section{REFERENCES GITED--Continued}

Rantz, S.E., and others, 1982, Measurement and computation of streamflow, volume 1, Measurement of stage and discharge: U.S. Geological Survey Water-Supply Paper 2175, 284 p.

Searcy, J.K., 1963, Flow-duration curves, manual of hydrology--Part 2, Low flow techniques: U.S. Geological Survey Water-Supply Paper 1542-A, 33 p.

Shaffer, P.W., 1982, Precipitation and streamwater chemistry, input and output budgets in the SWAS watersheds: Appendix V, in Shenandoah watershed acidification study, University of Virginia, $25 \mathrm{p}$.

Shaffer, P.W. and Galloway, J.N., 1982, Acid precipitation--The impact on two headwater streams in Shenandoah National Park, Virginia: Internationa1 Symposium on Hydrometeorology, American Water Resources Association, p. 43-53.

Sharpe, W.E., Leibfried, R.T., and DeWa1le, D.R., 1983, Fish Absent from 14 Laure1 Hill Streams: Institute for Research on Land and Water Resources Newsletter, v. 14, No. 2, 1 p.

Sharpe, W.E., DeWa1le, D.R., Leibfried, R.T., Dinicola, R.S., Kimme1, W.G., and Sherwin, L.S., 1984, Causes of acidification of four streams on Laure1 Hill in southwestern Pennsylvania: Journal of Enviromental Quality, v. 13, no. 4, p. 619-631.

Sharpe, W.E., Leibfried, V.G., Kimmel, W.G., and DeWa1le, D.R., 1987, The relationship of water quality and fish occurrence to soils and geology in an area of high hydrogen and sulfate ion deposition; Water Resources Bulletin, v. 23, no. 1, p. 37-46.

Statistical Analysis System Institute, 1979, SAS Users Guide, p. 763-774.

U.S. Department of Agriculture, 1983, Soils survey of Somerset County, Pennsylvania: Soil Conservation Service, 148 p.

U.S. Geological Survey, 1985-86, Water resources data for Pennsylvania, water year 1984-85--volume 3: U.S. Geologica1 Survey Water-Data Report PA-84-3 and PA-85-3 (published annual1y).

Walling, D.E., and Foster I.P.L., 1975, Variations in the natural chemical concentrations of river water during flood flows, and the log effect: some further comments: Journal of Hydrology, v. 26, no. 3/4, p. 238-243. 